\title{
FORMAÇ̃̃O DE EDUCADORES DE INFÂNCIA: PERCEÇÃO DE ESTUDANTES SOBRE A SUA FORMAÇÃO
}

Sandra Mónica Figueiredo de Oliveira Escola Superior de Educação Paula Frassinetti Portugal, Centro de Estudos em Desenvolvimento

Humano da Universidade Católica Portuguesa, Instituto de Investigação em Arte, Design e Sociedade da UP

Maria Clara de Faria Guedes Vaz Craveiro Escola Superior de Educação de Paula Frassinetti

- Portugal, Centro de Estudos Interdisciplinares em Educação e Desenvolvimento da Universidade Lusófona de Humanidades e Tecnologias

Brigite Carvalho da Silva Escola Superior de Educação de Paula Frassinetti

- Portugal, Centro de Estudos Interdisciplinares em Educação e Desenvolvimento da Universidade

Lusófona de Humanidades e Tecnologias

RESUMO: Este estudo pretende refletir sobre a formação de professores conferida por um Mestrado em Educação Pré-escolar, incidindo sobre a perspetiva dos estudantes de uma Instituição de Ensino Superior. Recorreu-se a uma metodologia de investigação quantitativa através de um inquérito por questionário cujo objetivo foi analisar o que pensam os estudantes sobre a sua formação e o impacto desta no seu perfil profissional. Os dados recolhidos permitiram perceber o grau de satisfação que os estudantes têm em relação à formação facultada oferecendo informações de suporte à avaliação global do curso e ao delineamento de planos de melhoria formativa.

PALAVRAS-CHAVE: formação de educadores/ professores, ensino superior, avaliação de ciclos de estudo, participação de estudantes

ABSTRACT: This study intends to reflect on the training of teachers conferred by a Masters in Pre-school Education, focusing on the perspective of the students of a Higher Education Institution. A quantitative research methodology was used through a questionnaire survey whose objective was to analyse what students think about their education and its impact on their professional profile. The data collected allowed to perceive the satisfaction level that the students have in relation to the training provided offering information to support the overall evaluation of the course and the design of training improvement plans.

KEYWORDS: Training of educators/teachers, higher education, assessment of study cycles, student participation

Nota: Este artigo foi publicado primeiramente na Revista de Estudios e Investigación en Psicología y Educación, 6, 0, 164 168, apresentando a seguinte referência bibliográfica: Oliveira, M.; Craveiro, C.; Silva, B. (2017). Formação de Professores: perceção de estudantes sobre a sua formação. Revista de Estudios e Investigación en Psicología y 


\section{I INTRODUÇÃO}

O mundo atual, cada vez mais caracterizado por inúmeras transformações no sistema económico, político, social e cultural a nível mundial, traz consigo um novo paradigma global e inúmeros desafios à sociedade, apontando na direção de um novo modelo educativo, visto o atual necessitar de ser renovado e ver reforçado o seu valor estratégico como fator determinante de inovação, de progresso, de competitividade e de excelência. Nesse sentido, e não esquecendo as palavras de Nóvoa, não é possível existir "ensino de qualidade, nem reforma educativa, nem inovação pedagógica, sem uma adequada formação de professores" (1992, p. 9). Para tal, têm sido evidentes os esforços para definir uma política educativa que oriente o destino dos cursos de formação inicial de professores cujo objetivo é cumprir os desígnios estipulados para o desenvolvimento de um novo modelo social na Europa. Várias têm sido as mudanças neles operadas, desde as organizacionais às concetuais, curriculares, institucionais ou ainda axiológicas, para as quais muito contribuiu a restruturação proveniente da Declaração de Bolonha (Reis \& Camacho, 2009; Estrela, 2010). Como afirma Ferreira \& Fernandes, "o processo de Bolonha proclamou novos desafios para as instituições de formação inicial de professores. Esses desafios decorrem, em parte, das alterações introduzidas no modelo de formação" (2015, p. 246).

Esta questão tem vindo a ser analisada não só por instituições formadoras mas também pelos diferentes intervenientes no processo educativo, sejam eles professores, investigadores ou estudantes. Porém, estes últimos têm ainda uma voz pouco ativa no processo de formação, sobre as aprendizagens realizadas e as competências desenvolvidas.

Nesta investigação entendemos que o estudante, como agente responsável, crítico, consciente e comprometido, interlocutor fundamental na sua educação, construtor do seu conhecimento, deve ser chamado a pronunciar-se sobre os diferentes aspetos do seu currículo, permitindo estudar a forma como a prática se desenvolve, quer num contexto de ensino e aprendizagem na sala de aula (Sacristán, 2000), quer num contexto mais alargado abrangendo toda a escola, quer no âmbito dos estágios profissionalizantes, em prol de uma melhoria da qualidade da educação (Gaspar \& Roldão, 2007).

Assim, analisar a formação inicial dos professores através da voz dos estudantes, é tentar compreender a importância que o currículo e todas as situações que visem as aprendizagens tiveram ou têm para eles; é, também, averiguar sobre os seus potenciais efeitos no seu perfil profissional, ponderando em que medida a formação atende às suas expetativas e vão ao encontro da realidade profissional por eles percecionada. Por último, mas não menos importante, é recolher junto dos estudantes um conjunto 
de propostas de melhoria para o currículo formativo.

Este artigo apresenta o seu enfoque sobre a perceção dos alunos que terminaram ou se encontram a terminar o Mestrado em Educação Pré-Escolar de uma Escola Superior de Educação, numa perspetiva que reflete a sua formação, o próprio desenvolvimento curricular e o impacto no seu perfil profissional, ou seja, o processo no qual o estudante está ou esteve envolvido e a projeção que é feita do currículo.

Para melhor compreender os resultados da auscultação efetuada aos estudantes é fundamental fazer-se uma breve caracterização do Mestrado em Educação PréEscolar em causa. Aprovado em junho de 2015, foi estruturado tendo em conta as alterações decorrentes do Decreto-Lei n 79/2014, de 14 de maio, nomeadamente quanto ao número de ECTS e componentes de formação.

A atribuição dos créditos ECTS às unidades curriculares (UC) tiveram subjacente os objetivos do ciclo de estudos, o perfil formativo e de competências do profissional na Educação de Infância, os aspetos científico-pedagógicos inerentes a cada UC e o limite mínimo de ECTS determinado para cada componente de formação pelo Decreto-Lei $n^{\circ} 79 / 2014$, de 14 de maio. Neste sentido, este ciclo de estudos possui 90 ECTS (3 semestres) tendo ficado distribuídos do seguinte modo: área de docência (9 ECTS); área educacional geral (18 ECTS); didáticas específicas (24 ECTS); prática de ensino supervisionada (39 ECTS). O curso apresenta, no total, 15 UC, estando estas distribuídas pelos semestres de forma equitativa (5 UC, correspondentes a 30 ECTS, por semestre). As UC de Prática de Ensino Supervisionada, pela natureza profissionalizante do curso, são as que representam um maior volume de ECTS deste ciclo de estudos (39 ECTS) sendo situadas em todos os semestres. Nos $1 .^{\circ}$ e $2 .^{\circ}$ semestres é realizada em contexto de jardim de infância e no $3 .^{\circ}$ semestre em contexto de creche. As 4 UC de Didáticas Específicas existentes no curso, apresentando cada uma 6 ETCS, representam também uma parcela significativa no plano de estudos. Estas UC incidem sobre a didática no âmbito de áreas como: Expressões Artísticas, Conhecimento do Mundo, Matemática e Comunicação Oral. Enquadradas na área educacional geral, encontram-se 4 UC com 32 ECTS e 1 UC com 64 ECTS. As UC desta componente de formação focam conteúdos ao nível da investigação em educação, da pedagogia da infância, da psicologia, introdução às necessidades educativas especiais e à ética e deontologia. Quanto à área de docência, a que corresponde 10\% dos ECTS totais do curso, encontramos 3 UC em que uma delas é de opção. Estas UC debruçam-se sobre conteúdos ligados à linguagem e literacia, às ciências naturais, à história, à geografia e às expressões artísticas.

Por último, importa salientar que este estudo se caracteriza por uma metodologia de investigação quantitativa, com recurso ao inquérito por questionário enquanto técnica de recolha de informações. Tendo por objetivo conhecer as perceções dos participantes sobre o assunto em estudo, a opção por esta metodologia decorreu não só da problemática, mas também dos pressupostos da investigação. Os dados daqui resultantes foram numa primeira fase organizados, descritos e depois interpretados de 
forma a, numa segunda fase, poderem ser transformados em resultados para a sua discussão.

\section{I MÉTODO}

\subsection{Participantes}

O estudo contou com a participação de 16 estudantes e 6 diplomados, de uma escola superior de educação que frequentaram o curso de Mestrado em Educação Pré-escolar nos anos letivos 2015/2016 e 2016/2017. Estes participantes, cujas idades se situam entre os 22 e os 27 anos com a exceção de uma estudante que tem 39 anos, são, na totalidade, do género feminino.

\subsection{Procedimentos}

Foi aplicado um inquérito por questionário a todos os sujeitos que frequentaram o Mestrado em Educação Pré-escolar nos anos de 2015/2016 e 2016/2017, obtendose uma taxa de respostas de $63 \%$. O instrumento foi disponibilizado numa plataforma online, por uma questão de melhor acessibilidade aos sujeitos que se pretendeu inquirir. O questionário abrangia um conjunto de perguntas fechadas (10), com possibilidades de resposta predefinidas, e perguntas abertas (11) com o intuito de permitir a expressão livre de perspetivas e opiniões. Os dados foram, consequentemente, analisados quantitativa e qualitativamente. Os dados daqui resultantes foram, numa primeira fase, organizados e sistematizados, recorrendo-se à elaboração de gráficos no caso das respostas às questões fechadas. Quanto às questões abertas, procedeu-se à análise de conteúdo das respostas. Numa segunda fase, efetuou-se a descrição dos dados de forma a proceder-se à análise e discussão dos mesmos.

\section{I RESULTADOS}

A análise do inquérito demonstra que a auscultação efetuada aos estudantes sobre a sua formação foi de forma global positiva ainda que estes tenham apresentado sugestões de melhoria. Relativamente à questão sobre se a formação inicial de educadores de infância é suficiente para uma prática profissional ao longo da vida, sete inquiridos consideram que não é suficiente. Destes sete respondentes, três referem que as exigências da sociedade e das crianças implicam procura de formação, pois "as crianças exigem cada vez mais de nós, a sociedade evolui e nós temos de as acompanhar." (R1). E quatro atestam que é fundamental uma atualização e desenvolvimento profissional: "um educador deve constantemente aprender mais, quer por via própria quer por formações específicas." (R7). Ainda em relação à mesma questão, doze inquiridos acham que só em parte a formação inicial é suficiente. Uma 
respondente justifica esta posição com base na perspetiva de que a experiência profissional vai completar a formação inicial. Oito respondentes fundamentam a resposta com base na necessidade de atualização e de desenvolvimento profissional, conforme o testemunho: "Estamos sempre em formação e, nesta área, não podemos ficar pela formação inicial, temos de estar sempre a atualizar o conhecimento." (R8). Três respondentes afirmam que a formação inicial é apenas uma primeira abordagem a ser completada e justificam-no com opiniões como "dá-nos uma primeira abordagem sobre a prática" (R11). Finalmente, como resposta à mesma questão, há três respondentes que consideram que a formação inicial é suficiente para uma prática profissional ao longo da vida. Destes três inquiridos um não justifica a resposta, mas os outros dois baseiam-se na perspetiva de que a formação inicial prepara para responder a situações ao longo da vida fornecendo as bases necessárias para enfrentar as situações profissionais como confirmam as seguintes justificações: "Considero que a formação inicial é suficiente para uma prática profissional ao longo da vida, pelo facto de nos dar as bases essenciais e necessárias para a nossa profissão." (R21)

No que diz respeito à questão "Considera que a habilitação profissional para a docência com nível de mestrado foi uma mais valia para profissão dos educadores de infância?", todos os inquiridos respondem afirmativamente exceto três que são de opinião que apenas o foi em parte. As respostas positivas dos dezanove respondentes são apoiadas por afirmações que sublinham a valorização da profissão, o aprofundamento de conhecimentos, o nível de especialização e a inerente qualificação que este nível de habilitação aporta. São evidência destas perspetivas afirmações como: "Acaba por dar ao futuro educador uma visão muito mais aprofundada do que é a realidade na Educação Pré-Escolar." (R16), "O mestrado prepara-nos de uma forma muito mais direcionada para o mundo do trabalho, oferecendo-nos assim, ferramentas essenciais para o nosso futuro como Educadoras." (R6) e "Torna a formação mais especializada" (R18). Os inquiridos que consideram que apenas em parte foi uma mais valia apresentam respostas muito diversas e baseadas na noção de que o mestrado é complementar da licenciatura.

Em relação à importância da formação no Mestrado em Educação Pré-Escolar, foi solicitado aos estudantes que a classificassem de acordo com a organização do plano de estudos. Os estudantes valorizam de forma mais positiva a duração do curso (três consideram muito adequado e dezasseis adequado), o número de UC por semestre (um considera muito adequado e dezassete adequado) e a sequência das UC (um considera muito adequado e quinze adequado). Os aspetos apontados como menos positivos são o tempo dedicado a práticas de investigação (quatro consideram inadequado e nove pouco adequado) e o tempo de trabalho autónomo (quatro consideram inadequado e sete consideram pouco adequado) bem como o tempo dedicado ao estágio. Neste ponto, embora os estudantes atestem os benefícios pedagógicos da PES, sugerem "estágios mais longos." (R22); "Mais horas de estágio e/ou dias completos." (R10) e "investir mais na prática supervisionada." (R12). 
No que diz respeito ao modo como classificam as unidades curriculares, os estudantes consideraram como menos positivo o volume de trabalhos e o tempo para estudo e realização de trabalhos (oito consideram pouco adequado e dois inadequado) atestando mesmo que "é complicado gerir o trabalho das UC, do estágio e relatório de investigação sem deixar nenhuma negligenciada." (R4). As formas de avaliação das UC foi o aspeto apontado como mais positivo, sendo que as metodologias de ensino e aprendizagem e a pertinência das UC também foram, por maioria, classificadas como adequadas.

Quando questionados sobre as competências adquiridas ao longo do curso que consideram mais importantes para o exercício profissional, as respostas são diversificadas. Amais mencionada é a responsabilidade (três), seguindo-se a autonomia, a capacidade de reflexão, o sentido crítico, a flexibilidade, a capacidade de cooperar, a adequação da intervenção às crianças (duas), a criatividade, investigação, a gestão de tempo, a adaptabilidade, o planeamento e a avaliação, (uma). Quanto aos aspetos sobre os quais consideram que o curso poderia ser melhorado, os respondentes apontaram uma diminuição da carga horária e uma melhor gestão do número de trabalhos solicitados referindo dificuldade em conciliarem as responsabilidades inerentes à prática pedagógica com a elaboração do relatório de estágio e das restantes UC. Propõem, ainda, mais aulas práticas, mais tempo para a investigação, haver uma maior incidência na formação no âmbito das necessidades educativas especiais e uma maior harmonização entre os professores de uma mesma unidade curricular. Apelam também a mais formação: "(...) sobre Creche." (R2), "Mais informação na área das Necessidades Educativas Especiais." (R16), "UC ligadas à Psicologia [...]" (R1), "[...] bem como uma componente mais prática da área da Plástica." (R1) e "Poderia existir formação em nutricionismo." (R7).

\section{I DISCUSSÃO}

A auscultação aos estudantes sobre a avaliação da sua formação, a sua participação nos processos de organização e funcionamento dos cursos decorre da perspetiva de que estes são atores das instituições com estatuto similar aos outros elementos que as compõem, complementando-se em pontos de vista e trazendo uma visão mais democrática, mais diversa e, consequentemente, mais enriquecida e completa às Instituições de Ensino Superior (IES), aliás como refere Cardoso (2010). Por outro lado, os estudantes são os principais interessados na qualidade da sua formação e constituem-se como "consumidores" dos serviços prestados pelas IES, concretamente da formação ministrada nos cursos que frequentam e, como tal, devem ter uma palavra a dizer sobre a mesma, com base na sua experiência de "clientes" (Cardoso, 2010). Como corolário, de acordo com o mesmo autor, o ponto de vista e o conhecimento que os estudantes possuem acerca da realidade académica, deve ocupar um lugar de destaque nas IES, dada a perspetiva ímpar que 
estes "destinatários" da formação detêm. Nesse sentido, este estudo aponta alguns aspetos que os estudantes realçaram sobre o mestrado em causa que gostaríamos de salientar, como a sua perspetiva de que a formação inicial, mais concretamente, o mestrado em Educação Pré-escolar, é o início da formação ao longo da vida. Para que um profissional possa responder com eficácia aos desafios da sociedade e das crianças necessita aprender continuamente e, neste sentido, a formação ao longo da vida constitui um alicerce de estruturação e desenvolvimento profissional (Comissão das comunidades europeias, 2000). Esta ideia está relacionada com "a perspetiva hoje dominante, de que a formação de um professor se integra num processo de desenvolvimento profissional ao longo da vida e, portanto, nunca está concluída." (Esteves, 2015, p.156).

Também se pode constatar que o mestrado é entendido, pelos estudantes, como uma forma de valorização formativa para a sua profissão. Neste sentido eles sublinham o aprofundamento de conhecimentos, o nível maior de especialização e a qualificação da profissão, e vai ao encontro da preocupação com a qualidade da formação dos docentes, na "preparação e valorização do respetivo estatuto sócio profissional" preconizada pelo Decreto-Lei n 43/2007, na sequência do Processo de Bolonha (Decreto-Lei n43/2007, preâmbulo).

No que diz respeito à organização do plano de estudos, é possível perceber que os estudantes se encontram manifestamente satisfeitos com a duração do curso, o número de UC e a sua sequência nos semestres. Porém é importante referir que há uma perceção por parte dos respondentes de que o tempo destinado ao estágio é diminuto, tal perspetiva está em consonância com a opinião de Craveiro quando refere que "o contacto com a prática profissional, (...) nos Mestrados Profissionalizantes, é muito reduzido para um educador de infância que se deseja qualificado de forma competente e minimamente experiente na prática profissional, para poder enfrentar a realidade à saída do curso e ingressar na profissão." (2016, p.35) mais acrescenta que "este estágio é uma aparição tardia, no percurso de formação de um estudante futuro educador." (Craveiro, 2016, p.35-36). Um outro aspeto apontado prende-se com a recorrente alusão a aspetos da investigação no curso, pois como define o Decreto-Lei $n^{\circ} 43 / 2007$, a formação em metodologias de investigação educacional é imprescindível. A investigação, para Pimenta e Lima (2011) deverá acontecer numa articulação estreita com o estágio, aspeto sublinhado neste estudo através de referências ao Relatório de Estágio. Por último, os estudantes apontam ainda o tempo para trabalho autónomo, indicado como desadequado pois parece haver uma discrepância entre o tempo previsto pelo docente para a realização das tarefas autónomas e o tempo efetivamente utilizado pelo estudante para a realização das mesmas (Ramos, Delgado, Afonso, Cruchinho, Pereira, Sapeta \& Ramos, 2013).

As preocupações relativas ao volume de trabalho que o curso exige e a respetiva dificuldade na gestão do mesmo, mencionadas pelos inquiridos, talvez decorra do facto dos planos de estudo pós-Bolonha se caracterizarem por uma excessiva fragmentação 
dos saberes, decorrente de uma organização em unidades curriculares, de duração semestral e que pulverizam os saberes por um extenso número de UC (Sá-Chaves, 2015).

As necessidades de formação efetuadas através de propostas de melhoria, apresentadas pelos inquiridos, evidenciam uma grande diversidade de conteúdos e áreas, o que está de acordo com a perspetiva de que o "conhecimento profissional necessário a um bom desempenho profissional da prática docente dos educadores de infância é múltiplo e heterogéneo, construído antes, durante e após o seu processo de formação inicial, cuja origem deriva de fontes de diversas naturezas." (Horta, 2015, p.279).

Em termos globais os estudantes consideram que o mestrado os preparou para o exercício profissional através da aquisição de competências que concorrem para o seu perfil profissional e que lhes permite enfrentar os novos desafios da sociedade contemporânea.

Promover práticas de auscultação dos estudantes, sobre os assuntos que lhes dizem diretamente respeito, como é o caso dos cursos que frequentam, contribui para edificar e desenvolver os sistemas de avaliação e garantia da qualidade nas IES (Cardoso, 2010) e para potenciar as respostas mais consentâneas com as necessidades e as expectativas dos estudantes no início e ao longo dos ciclos de estudo que frequentam. Neste contexto, estudar a perceção dos estudantes, entendida como a interpretação que os mesmos fazem da realidade vivida, constitui um contributo valioso e único para o desenvolvimento da qualidade dos ciclos de estudos.

\section{REFERÊNCIAS}

BOGDAN, R.; BIKLEN, S. Investigação Qualitativa em Educação - Uma introdução à teoria e aos métodos. Porto: Porto Editora, 1994.

Comissão das comunidades europeias. Memorando sobre Aprendizagem ao Longo da Vida. Lisboa, 2000. Disponível em:

https://infoeuropa.eurocid.pt/files/database/000033001-000034000/000033814.pdf. Acesso em: 8 jan. 2017.

CRAVEIRO, C. Formação de educadores de infância, realidade e identidade profissional em análise. RELAdEI - Revista Latino americana de Educación Infantil, Santiago de Compostela: Facultad de Ciencias de la Educación v.5, n.14, p. 31-42, dez. 2016. Disponível em: http://redaberta.usc.es/reladei/ index.php/reladei/article/view/360/pdf. Acesso em: 8 jan. 2017.

Portugal. Decreto-Lei n. ${ }^{4}$ 43/2007, 22 de fevereiro de 2007, Regime jurídico da habilitação profissional para a docência na educação pré-escolar e nos ensinos básico e secundário. Disponível em: https:// dre.pt/pesquisa//search/517819/details/maximized. Acesso em: 8 jan. 2017.

Esteves, M. Formação inicial de professores: saber mais para agir melhor. In Conselho Nacional de Educação (Ed.). Formação Inicial de Professores (pp. 272-282). Lisboa: Conselho Nacional de Educação, 2015, p.156-165. Disponível em: http://www.cnedu.pt/content/edicoes/seminarios_e_ coloquios/LivroCNE_FormacaolnicialProfes, Acesso em: 8 jan. 2017.

ESTRELA, M. Complexidade da epistemologia do Currículo. In C., Leite et al. (Ed.). Políticas, 
FERREIRA, P.; FERNANDES, P. Supervisão Pedagógica em Contexto de Formação Inicial de Professores do $1 .^{\circ} \mathrm{CEB}$ : Uma Análise focada nos relatórios de estágio. Saber \& Educar, Porto: ESEPF, 2015. n. 20, p. 244-253.

GASPAR, M.; ROLDÃO, I. Elementos do Desenvolvimento Curricular. Lisboa: Universidade Aberta, 2007.

HORTA, M. H. (2015). Que educadores desejamos? Que educadores formamos? Conselho Nacional de Educação (Ed.). Formação Inicial de Professores Lisboa: Conselho Nacional de Educação, 2015. p. 272-282. Disponível em: http://www.cnedu.pt/content/edicoes/seminarios_e_coloquios/ LivroCNE_FormacaolnicialProfes, Acesso em: 8 jan. 2017.

NÓVOA, A. Os professores e a sua formação. Lisboa: Dom Quixote, 1992.

PIMENTA, S.; LIMA M. Estágio e docência. São Paulo: Cortez Ed., 2011.

PINHO, A.; CRÓ, L.; DIAS (2013). A formação de educadores de infância: práticas adequadas ao contexto educativo de creche. Revista Portuguesa de Pedagogia, Coimbra, 2013. v.47, n.1, p.109125.

RAMOS, A.; DELGADO, F.; AFONSO, A.; PEREIRA, P.; SAPETA P.; RAMOS, G. Implementação de novas práticas pedagógicas no Ensino Superior. Revista Portuguesa de Educação, Braga: Instituto de Educação - Universidade do Minho, 2013, v.26, n.1, p.151-141.

REIS, P.; CAMACHO, G. A avaliação da concretização do processo de Bolonha numa instituição de Ensino Superior portuguesa. Revista Española de Educación Comparada, Madrid: Faculda de Educación, 2009. n.5, p.41-59.

SÁ-CHAVES, I. Um olhar/um contributo. In Conselho Nacional de Educação (Ed.). Formação Inicial de Professores Conselho Nacional de Educação. Lisboa: Conselho Nacional de Educação, 2015. p.272-282. Disponível em: http://www.cnedu.pt/content/edicoes/seminarios_e_coloquios/LivroCNE_ FormacaolnicialProfes Acesso em: 8 jan. 2017

SACRISTÁN, J. O Currículo: uma reflexão sobre a prática. Porto Alegre: Artmed, 2000. 


\section{O QUE FAZEMOS COM O QUE FAZEM CONNOSCO... INTERAÇÔES QUE (NOS) FORMAM E DESENVOLVEM}

Teresa Sarmento Instituto de Educação - Universidade do Minho Braga, Portugal Conceição Leal da Costa Escola de Ciências Sociais-Universidade de Évora

\footnotetext{
"No seu aspecto mais profundo, o meu conhecimento de mim própria, é obscuro, interior, inexpresso, secreto como uma cumplicidade"

(Marguerite Youcenar, Memórias de Adriano)
}

RESUMO: Os professores desenvolvem-se numa teia relacional, com crianças, pais, pares profissionais, e outros, o que se constitui num processo formativo bem estruturado, desde que reflitam contínua e sustentadamente nas suas experiências. $O$ texto que aqui se apresenta decorre de uma investigação internacional que tem como base empírica narrativas biográficas, as quais nos permitem a construção de conhecimento sobre identidades profissionais e vidas de professores. As questões de partida são: As crianças e os EE têm algum papel no trabalho dos professores? Qual o papel dos professores na vida das crianças e das suas famílias? Como conjugam expectativas profissionais com as das famílias? Como se formam e desenvolvem os professores com essas interações? Os resultados desocultam múltiplas oportunidades de interação que os docentes vivenciam nos quotidianos, enfatizando as emocionalmente mais impregnantes ou mais formativas, em que as crianças e as suas famílias constituem os principais pilares com quem cada professor estabelece relação.

PALAVRAS-CHAVE: identidades profissionais; narrativas biográficas; interações educativas e formativas.

ABSTRACT: Teachers develop themselves in a relationship with children, parents, professional peers and others, what is a good structured personal and professional formation, as long as they reflect continuously and sustainably in their experiences. This paper is based on an international research with an (auto)biographic empirical reference, which allow us to build knowledge about professional identities and the lives of teachers. The starting points are: do children an tutors of them have any role in the work of teachers? What is the role of teachers in the lives of children and their families? How do they combine professional expectations with those of families? How are teachers formed and developed with these interactions? Results uncover multiple opportunities for interaction that teachers experience in everyday life, emphasizing those that are emotionally more impregnating or more formative, in which children and their families are the main pillars with which each teacher establishes a relationship.

KEYWORDS: professional identities; biographic 


\section{INTRODUÇÃO}

Os professores desenvolvem-se numa teia relacional, com crianças, pais, pares profissionais, e outros, o que se constitui num processo formativo bem estruturado, desde que reflitam contínua e sustentadamente nas suas experiências.

O texto que aqui se apresenta decorre de uma investigação internacional que tem como base empírica narrativas biográficas, as quais nos permitem a construção de conhecimento sobre identidades profissionais e vidas de professores. As questões de partida são: As crianças e os EE têm algum papel no trabalho dos professores? Qual o papel dos professores na vida das crianças e das suas famílias? Como conjugam expectativas profissionais com as das famílias? Como se formam e desenvolvem os professores com essas interações?

Os resultados desocultam múltiplas oportunidades de interação que os docentes vivenciam nos quotidianos, enfatizando as emocionalmente mais impregnantes ou mais formativas, em que as crianças e as suas famílias constituem os principais pilares com quem cada professor estabelece relação.

\section{AS NARRATIVAS (AUTO)BIOGRÁFICAS NA ABORDAGEM À CONSTRUÇÃO DO CONHECIMENTO PESSOAL E PROFISSIONAL}

As narrativas, sob a forma oral ou escrita, podem constituir-se um método de estudo poderoso em Educação. Fazendo valer o que parafraseámos de Marguerite Youcenar em epígrafe, o conhecimento de si é obscuro, interior, inexpresso e secreto, mas pode tornar-se exterior se mediado. A escuta, a reflexão, a análise de conteúdo e a (re)interpretação permitem alcançar, simultaneamente, espacio-temporalidades e evolução de acontecimentos, nomeadamente na construção do conhecimento profissional dos professores, a partir de encontros entre história e memória e confrontos entre voz interior e voz exterior. Configurando o sujeito epistémico sem esquecer o sujeito biografado, nesta linha, a abordagem biográfica permite-nos refletir e investigar de forma participada e a partir da complexidade da profissão. Daqui resulta uma construção (com)partilhada de saberes com voz, valorizando igualmente a ecologia do desenvolvimento profissional.

Muitos são já os estudos sobre os professores, seja sobre a formação, a profissionalização, o conhecimento, a vida, o pensamento ou outras dimensões, interessando-nos particularmente a abordagem sobre as identidades profissionais (Sarmento, T., 2002; Leal da Costa, 2015). Dentro deste âmbito, mobilizamos para este texto a assertiva de que o professor é um profissional do humano, um interventor mais ou menos consciente e crítico do seu papel social, cuja ação se desenvolve na interação com outras pessoas. Como diz Nóvoa (1992) "Ser professor obriga a opções 
constantes, que cruzam a nossa maneira de ser com a nossa maneira de ensinar e que revelam na nossa maneira de ensinar a nossa maneira de ser" (p. 9); ou seja, ser professor é, a um tempo só, ser pessoa e profissional. Nessa perspetiva, a ação docente só faz sentido se estiver fortemente impregnada de um compromisso social com os estudantes, com os pares e no contexto que habita, pensando no que é mais imediato, mas também com a sociedade e a cultura, em termos mais globais. Neste texto desafiam-nos, portanto, os modos de configuração pelos quais as experiências vividas são mantidas e associadas, mas permanecem amplamente desconhecidas e não são reconhecidas. Envolvidos nos quotidianos, os pensamentos estruturados e que sustentam a conduta da sua vida de professores, ficam muitas vezes descuidados e "ocultados" para si e desconhecidos para os outros, ficando o professor como que refém do pensamento rotineiro que, individualmente, é incapaz de valorizar e transformar em conhecimento. No entanto, o que se sedimenta na memória é também o que possibilita a atividade biográfica, especialmente o que os sujeitos tornaram experiência e, portanto, um percurso de (re)construção identitária que efetivamente não ficou inerte desde a formação inicial, quando falamos de identidade profissional de professores.

Questionar experiências que se tornaram memórias (momentos vividos, acontecimentos, relações em temporalidades da vida) envolve operar no rescaldo da caminhada, proporcionar a reflexão e gestos que permitam um "voltar-se para si", interessado novamente sobre algo. Por outras palavras, remete para o nosso papel de formadores de professores, uma compreensão mútua que pressupõe olhares sobre processos singulares, mas que só a comunicação com feedback reflexivo oferece possibilidades de 'fabricação do mundo interior da vida exterior', a metabolização e a apropriação pelo indivíduo - e por um indivíduo necessariamente singular dos ambientes de todo o tipo que são os seus" (Delory-Momberger, 2016, p.141). Enquanto docentes da universidade e investigadoras a biografização e a investigação com narrativas mantêm íntima relação, tornando-se necessariamente indissociáveis nas operações e processos de configuração identitária, ou mais propriamente do que é, para cada um e para todos, ser professor.

Encontramos em Roldão (2017) a clareza das palavras que nos permitem pensar sobre a função de ensinar, enquanto definidora da existência deste grupo. Diz a autora que existe um enleio "numa teia de significados que historicamente se foram desenvolvendo, inevitavelmente ideologizados e necessariamente não neutros, acarretando algumas contradições" (p. 1138). Assim, atribuindo uma dupla formalização funcional do que tem vindo a ser professor "entre "promover a transmissão de um saber', ou 'promover intencionalmente a aprendizagem desse saber pelo outro, faz toda a diferença no que se refere à conceptualização do que são os elementos do conhecimento profissional docente" (Roldão, 2017, p. 1138). A evolução socio-histórica da escola e da educação escolar mostra o quanto se têm ampliado as funções dos professores, redimensionando, inclusivamente, a natureza e 
a construção do conhecimento profissional. Apesar de haver uma gramática escolar e profissional que parece perpetuar-se, há hoje uma firme consciência da necessidade de mudar a formação e, com ela, a profissão (Nóvoa, 2017). Entendendo que ensinar pode ser caracterizado pela "figura da dupla transitividade e pelo lugar da mediação", entendendo que ensinar é, então, "fazer aprender alguma coisa a alguém" (Roldão, 2007, p. 95), na base dessa ação desempenhada pelos professores estão, necessariamente, múltiplos tipos de conhecimentos, que incorporam saberes de conteúdo, saberes didáticos, saberes relacionais, de ação concreta e com significado socio-histórico. Montero (2005) aponta a incorporação de saberes mobilizados pela participação dos professores nas suas experiências formativas e de ação direta em sala de aula "... manifestadas no seu conjunto com as exigências da complexidade, incerteza, singularidade e conflito de valores próprios da sua actividade profissional; situações que representam, por sua vez, oportunidades de novos conhecimentos e de crescimento profissional" (p. 218), o que se reforça com a afirmação de Nóvoa (2009), segundo o qual "Hoje, a realidade da escola obriga-nos a ir além da escola", ou seja, não basta instruir, há que colaborar na socialização, na inclusão social, na construção partilhada de valores (p.31). Pensando do ponto de vista da construção do professor, pode significar que temos que cuidar da "incorporação de um conjunto de "disposições duradouras", e a possibilidade de este património ser transferível através de um processo de socialização profissional” (Nóvoa, 2017, p.1119).

Ora, nesta linha de entendimento, onde imperam os consensos em torno da incerteza e da complexidade na profissão docente, consideramos que para compreendermos a ação, as crenças, os conhecimentos, os pressupostos, as finalidades dos professores, temos que ouvir e desocultar de sentido as suas narrativas, já que, como defendem Connelly e Clandinin (1990), "O estudo da narrativa é o estudo da forma como os seres humanos experimentam o mundo. Esta noção geral transfere-se para a concepção da educação como construção e reconstrução de histórias pessoais e sociais; professores e alunos são narradores e personagens das suas próprias histórias e das histórias dos outros" (p.2).

Uma abordagem sobre identidades dos professores não pode ignorar as suas histórias de vida, as quais nos permitem aceder ao conhecimento das suas experiências e do significado que os atores sociais (neste caso, os professores) atribuem a essas experiências como fundadoras de si enquanto profissionais. Ao narrar, o sujeito cria sentido às suas experiências prévias, transformando-se essa atribuição de significado em formação (Josso, 2002), dimensão esta fulcral para a construção da sua identidade. Interessa aqui reconhecer o valor que os atores sociais atribuem às suas memórias como intervenientes na sua formação profissional, realçando as interações estabelecidas ao longo da vida com pessoas significativas, em contextos sociais em que cada pessoa-professor se vai construindo e reconstruindo (Sarmento, T. 2009; Costa e Cavalcante, 2017).

O processo de construção de uma história de vida implica um campo de forças 
e de poderes em que cada um constrói a sua posição em relação consigo mesmo e com os outros e, portanto, a construção identitária entendida como processo (Nóvoa, 2017). Embora se trate de um caminho interno à própria pessoa, não pode ser deslocado dos contextos onde vai ocorrendo a passagem e de quem influencia a sucessiva construção de sentidos (Dubar, 2000). No fundo, é um processo baseado nas vivências e experiências relevantes que decorreram no decurso da sua própria vida, nas diferentes configurações em que se enleou. Na linha de Josso (2002), a passagem que cada ator faz da vivência enquanto ocorrência factual para a experiência em que há já uma seleção e integração de sentidos, leva, pela atribuição de significado, a novo conhecimento incorporado pelo sujeito-professor na sua forma de ser e, daí, na sua forma de agir. Encadeando relações entre passado, presente e futuro, para Connelly \& Clandinin (1988), o conhecimento de cada professor parte de uma forma própria de o mesmo reconstruir o passado e de definir intenções para o futuro em diálogo com as exigências das situações presentes.

O acesso a narrativas biográficas de professores permite-nos enunciar algumas ideias que nos parecem centrais para a abordagem das identidades profissionais dos professores. Em primeiro lugar, evidencia-se a relevância da profissão professor como "profissão do humano" (Boltanski, 1982), em que o ser pessoa é o centro em torno do qual as ações pedagógicas ganham significado. Daí a importância da formação pessoal ao longo da vida, "propiciadora (ou não) da construção de competências relacionais que viabilizem o reconhecimento do Outro (alunos, professores, pais) como pessoa com a qual se promove educação" (Sarmento, T., 2009, p.326). Carlos Marcelo lembra que, para além do conhecimento de conteúdo, para ensinar os professores precisam ter outros conhecimentos: "o conhecimento do contexto (onde se ensina), dos alunos (a quem se ensina), de si mesmo e também de como se ensina" $(2010,13)$. Este autor, reforçando que a "identidade não é um atributo fixo para uma pessoa, mas sim um fenómeno relacional" (p. 20), assinala que a mesma decorre de um processo evolutivo de reinterpretações contínuas das experiências, as quais promovem aprendizagens ao longo da vida. Neste sentido, entendendo a formação inicial e contínua como andaimes para as identidades profissionais, subscrevemos Severino (2006), o qual defende que a "formação significa a própria humanização do homem [...] é processo do devir humano como devir humanizador, mediante o qual o indivíduo natural devém um ser cultural, uma pessoa" (p.621).

Esta referência ao desenvolvimento do professor como pessoa, remete ainda para um conceito de aprendizagem ao longo da vida que admite vários níveis e interseções de perspetivas: macro, meso e micro. Esta última, a micro-perspetiva, será a que mais nos interessa para este texto.

São pressupostos desta visão que a natureza da educação do ser humano se tem alterado na contemporaneidade, através das mutações tecnológicas e sociais que se vão vivendo. Estes estudos, apontam que os sujeitos assumem hoje um tipo de conhecimento e compreensão dos assuntos que não assenta em conhecimentos 
específicos e permanentes. Simultaneamente, a ideia de aprendizagem ao longo da vida, e especialmente auto-aprendizagem, parece muito coerente com este processo. Segundo o autor, num quadro de aprendizagem que acontece ao longo da vida, cada um na sua individualidade integra novas experiências, mas este processo é social e as interações moldam ativamente os sujeitos, tornando-os capazes de mudar o seu mundo social. Consequentemente e pensando em professores enquanto grupo profissional, a construção identitária pode ser vista como uma ação coletiva entre professores, mas também nas interações com as crianças e as comunidades, porque a educação é, também ela, uma ação coletiva. É na interação dos professores com as crianças e as comunidades que se fazem aprendizagens essenciais, não técnicas, mas fundamentais no exercício da profissão. É no contato com situações reais, com crianças não padronizadas, com a diversidade de populações, que os professores redefinem a forma de ver o mundo, o que os obriga a racionalizar emotivamente sobre a ação de professor: alguém que ensina, que transmite mas, sobretudo, quem tem que aprender como tornar significativos os saberes com as crianças e consigo próprio, em vista à finalidade última da educação que é promover cada um enquanto pessoa, sem esquecer que as metamorfoses da existência almejam um bem comum.

\section{UMA APRESENTAÇÃO DO PROJETO O QUE FAZEMOS COM O QUE FAZEM CONNOSCO...}

Os professores são atores sociais com um mandato próprio - cumprirem determinadas finalidades educativas, que se distribuem por funções como a instrução, a socialização, a personalização e outras -, que desenvolvem a sua ação em escolas social e historicamente situadas. Ora, retomando um texto recente (Sarmento, 2017), reafirmamos que não há um universal de sociedade, mas que há sociedades concretas, localizadas em espaços e tempos específicos. No entanto, verificam-se alguns fenómenos comuns nos tempos atuais que nos obrigam a entender este mundo como uma sociedade ampla, sujeita a esse processo designado de globalização, que oculta, e muitas vezes faz submergir, os traços identitários de cada comunidade. A globalização é um fenómeno multidimensional, abrangendo ou afetando dimensões políticas, culturais, ambientais, sociais, tecnológicas, logo, aspetos fundamentais quando se pensa em educação e nos professores. São muitos os autores que nos mostram, ainda que de forma nem sempre direta, a relação de proximidade entre a globalização e a visão atualmente dominante no campo da educação e da formação de professores: ou seja, da relação estrita entre o poder económico e a tendência crescente para uma formação de base reprodutora, ao serviço de uma sociedade sustentada numa ideologia neoliberal, com repercussões na construção identitária dos professores, o que leva a ignorar e desperdiçar o seu potencial construtivo, remetendo-os para um papel passivo, de mero canal transmissivo. Recusando esses posicionamentos extremos, inserimo-nos no grupo de profissionais - investigadoras/ 
professoras - que acreditam que faz sentido questionar a hegemonia dessas posturas, fazendo para nós sentido ouvir o que nos dizem os professores sobre como, nestas sociedades, (re)constroem as suas identidades, ao longo das suas trajetórias profissionais. No fundo, pertencemos ao grupo dos que como refere Nóvoa (2017) acreditam na transformação, num caminho que continua e não enclausura, pois os determinismos "são insuficientes e incapazes de traduzir a complexidade da profissão docente e dos seus processos de formação" (p.1118). Da improvisação e tomadas de decisão em realidades diversas, a vivencias, encontros ou acontecimentos que dependem dos grupos e contextos aos quais se pertence ou se está inserido, há aspetos que se revestem sempre uma dimensão colectiva que afeta o professor, mas insistem na possibilidade e autonomia que um agir e intervir consciente permite mudar, em si, nos outros e nos contextos. aproximações se baseiam no pressuposto de que é possível preestabelecer um conjunto de características definitórias do futuro profissional.

O presente texto decorre de uma investigação internacional, desenvolvida por investigadoras portuguesas e brasileiras, com o foco na construção de conhecimento sobre identidades profissionais e vidas de professores experientes. A junção de investigadoras portuguesas e brasileiras deu-se a partir do interesse comum por métodos biográficos (histórias de vida, memoriais de formação, narrativas biográficas) e pela formação de professores. A investigação iniciou-se no âmbito do projeto de um ano sabático de uma das investigadoras, a qual, inserida em rede internacional, entendeu ser a integração das colegas uma forma de coletivamente se alargar e aprofundar o conhecimento desta área e, sobretudo, de afirmar esta metodologia científica no mundo académico. Em comunidade de aprendizagem decidimos que os estudos realizados no âmbito deste projeto podem ser realizados de forma independente ou em grupos de dimensão variada, desenvolvendo estudos em equipa integral e por grupos restritos, seja num ou nos dois países, com vantagens para a amplitude territorial, espaciotemporal e número de narrativas que permite abarcar.

Sustentada na designação de "O que fazemos com o que fazem connosco... identidades profissionais em (re)construcão", e com a finalidade de analisar como as identidades profissionais comportam mudanças a nível dos princípios e finalidades educativas dos professores, a investigação parte da seguinte questão: Como integram os professores na sua identidade profissional as alterações que se processaram nas últimas décadas na sociedade em geral, na sua vida pessoal e no sistema educativo em particular? Como principais objetivos pretende-se compreender como se repercutem na construção de saberes e nas identidades profissionais, a evolução do conhecimento de diferentes ciências da educação, as alterações organizacionais, a formação de professores, as dinâmicas sociais, a(s) ideologia(s) educacional(is) vigente(s), as interações com crianças e outros, e as experiências de vida pessoal.

Os sujeitos biografados são professores de crianças dos 3 aos 12 anos de idade, do Brasil e de Portugal, que têm mais de 20 anos de prática docente, sendo considerados 
como bons professores pela comunidade profissional. A identificação dos mesmos foi realizada de forma deliberada, por consulta de vários elementos (conhecimento pessoal, trabalho e cooperação na formação de professores, colegas, gestão da escola, sindicatos), de forma a podermos garantir à partida que estamos perante profissionais cujo consentimento informado e participação numa investigação com estas características era sinónimo de vontade própria de (re)construção profissional. Considerando que "história implica passado, implica experiência" (Sarmento, T. 2002, p. 273), definimos à partida que tínhamos que selecionar professoras com um tempo alargado de serviço. Ao mesmo tempo, assumindo que as identidades são entendidas como construções realizadas por cada agente social na interação com a multiplicidade de contextos de que participam, antecipamos que teríamos que escolher professoras com um número alargado de experiências socioprofissionais.

Em termos metodológicos optámos pelo método biográfico, com entrevistas narrativas, por considerarmos ser esta a técnica mais adequada face ao objeto de estudo e à concretização dos nossos objetivos. Ou seja, no sentido de conhecermos pessoas no seu processo de construção profissional, no âmbito da sua inserção num grupo profissional em desenvolvimento na contemporaneidade e em contexto de trabalho, permitindo reconhecer "A fusão deste duplo movimento (que) significa reconstrução dialéctica entre a sociedade e um indivíduo em particular" (Ferrarotti, 2013, p. 65).

Entre as quatro dimensões que o projeto almeja investigar - formação, experiência, interações e inserção em organizações - selecionamos para esta apresentação o que pretendemos conhecer e compreender acerca das interações com crianças enquanto constitutivas e (re) construtoras de identidades profissionais.

As questões de partida deste estudo parcelar são: as crianças e os seus encarregados de educação influenciam na definição do trabalho dos professores? Qual o papel dos professores na vida das crianças e das suas famílias?

As entrevistas a oito professoras portuguesas que integram o presente estudo foram realizadas em dois momentos, mediados por um espaço de duas a três semanas, de forma a possibilitar a transcrição, a devolução às entrevistadas para sua ratificação e mobilização de novas memórias, na base da defesa feita por Nóvoa (1992, p.37) que numa metodologia qualitativa se tem que manter "uma responsabilidade social e ética (que) obriga o investigador a uma vigilância crítica sobre si próprio". Simultaneamente, quisemos acautelar um certo feedback reflexivo, que como sugere Breton (2018) possibilitasse reflexões mais profundas e com outros contornos, não esquecendo que uma outra entrada do nosso estudo é a formação dos professores em diferentes nuances. No primeiro tempo de entrevista, as questões foram lançadas de forma muito aberta, flexível, numa busca de interações orais diretas, geradoras de confiança e de produção de informações (Cohen; Manion, 1990; Poirier et al, 1995; Bertaux, 1997). Cada entrevista foi então transcrita e sujeita a uma análise flutuante, no sentido de realizada ainda com alguma leveza, sem estar sujeita a grandes categorizações, 
com o propósito de nos irmos apropriando dos conteúdos e do sentido das mesmas. O segundo momento, norteado por essa análise prévia, foi já mais direcionado, procurando delimitar questões concretas que nos ajudassem a garantir a recolha de dados respondentes aos objetivos pré-definidos no desenho da investigação. $\mathrm{Na}$ identificação dos estratos integrados no ponto seguinte é indicado o nome pelo qual cada narradora decidiu ser designada, seguindo-se El significando que é educadora de infância, logo, a sua experiência de trabalho é com crianças dos 3 aos 6 anos, ou $1^{\circ} \mathrm{Cc}$, ou seja, é professora do $1^{\circ} \mathrm{Ciclo}$, sendo a sua experiência docente realizada com crianças dos 6 aos 9 anos de idade.

\section{REFLETIR EM INTERAÇÕES DE PROFESSORES COM CRIANÇAS}

A escuta de narrativas de professoras permitiu-nos compreender como as interações com crianças se vão diversificando, ao longo das trajetórias profissionais, consoante o ciclo educativo em que atuam, a maior ou menor dependência da regulação educativa e das suas circunstâncias de vida. As mudanças que acontecem ao longo dos percursos são momentos que marcam a vida profissional dos professores e que fazem mudar os seus olhares sobre a criança, o que se traduz em formas diversas de trabalhar com as mesmas.

Conhecedoras de que a vida das crianças de hoje é muito diferente das suas próprias vidas, apoiadas em memórias eufóricas das suas infâncias - "Eu fiz coisas, fiz coisas que os meninos hoje não conseguem fazer, ou não têm oportunidade de fazer" (Ana, El) - aliado ao compromisso de efetivar os direitos que a Declaração Universal dos Direitos da Criança e a Declaração de Salamanca promulgaram, leva estas profissionais a repensarem muitas das suas ações. No próprio ato de produção da narrativa, a Cristina reflete na sua ação pedagógica balizando-a com as suas memórias de infância: "Nós às vezes agimos muito como adultos, por exemplo, eu tinha imensa dificuldade em comer, a minha mãe punha-me o prato de comida, eu achava sempre que aquilo era imensa comida, e sei o que sofri a olhar para a comida e não me apetecer comer, não ter vontade...não conseguir comer, e ser obrigada a comer. $E$ às vezes custa-me imenso passar ali na cantina e vê-las (às crianças) serem obrigadas a comer ... eu arranjo ali uma brincadeira e metade da comida desaparece! ... elas têm direito a não gostar, têm direito a não gostar de fazer determinada coisa, têm direito a não gostar de comer determinado alimento, e têm direito a gostar de fazer mais umas coisas do que outras".

Ao articularem o seu passado com o seu presente, estes olhares são integrados na forma de ver, de pensar e de ser dos professores, o que é incorporado nas suas práticas profissionais; a pessoa/profissional vai-se transformando mediante o contexto externo, a partir da interação que estabelece entre o que é seu (crenças, saberes, valores, práticas) e o que é do contexto (as crianças, as condições sociais, os conhecimentos, as orientações globais,...). 
Torna-se também evidente na análise destas narrativas que ao mesmo tempo que dirige a atenção das crianças para a compreensão de novos saberes, o professor aprende com as próprias crianças (Pramling, 2006; Sarmento, T. 2016). Como diz a Cristina (EI) "(...) os grupos fazem o nosso trabalho, há grupos que temos que fazer andar e há grupos que nos fazem andar, que estão sempre a pedir coisas(...)", ou como salienta a Dulce (EI) “(...) As crianças têm as reações mais estranhas até nós percebermos o porquê, o que é aquela reação e quando acontece, mas é preciso compreendê-las.... Geralmente, é face a essas atitudes, nessas situações que eu acho que ainda preciso de saber muita coisa, quer para abordar os pais quer para os escutar quando me contactam". Nesta dinâmica interativa ficou claro que "as crianças tomaram centralidade, tornando-se agentes na ação e na formação, de si e dos adultos, partindo-se do que sabiam e não de deficits" (Leal da Costa \& Nunes, 2016, p. 133).

$\mathrm{Na}$ narrativa de Isabel $(E \mathrm{I})$, tal como em outras, é manifesto o compromisso com a vida das crianças, reforçando-se o caráter humano da profissão docente: "Mantenho um compromisso ético com as crianças mais vulneráveis (DDC, 1989, art 28 e 29), como um direito a todas as crianças, criando igualdade de oportunidades. Procuro desenvolver a qualidade do ambiente educativo, em que a sala pretende ser um espaço com sentido, um microcosmos de uma sociedade democrática e de cidadania, criada pelas crianças, de onde irradia toda a vida do jardim-de-infância".

Em algumas narrativas é possível descortinar a ambiguidade entre o uso de discurso correto em que a criança é reconhecida como agente, ator social participante nos processos de decisão. Por outras palavras, encontramos uma narrativa que parece manifestar a ideia de uma educação de qualidade que pressupõe que as crianças tenham oportunidade de interagir umas com as outras, com os adultos e com o ambiente, como anota Katz (2006) - "Nesta dinâmica de trabalho, todos participam, todos planificam as suas atividades, todos vão inventariando os problemas e arranjam soluções" (Teresa, El) -, mas, ao mesmo tempo, ainda que muito bem intencionado, um discurso fortemente normativo, em que o deve e o tem que está demasiado presente - "o educador é aquele que orienta, que desperta na criança o desejo de construir o seu próprio conhecimento" (Teresa, El) -, revelando uma postura transmissiva, de quem, externamente, leva o conhecimento e a vontade de aprender à criança. Neste caso parece-nos evidenciar-se que a educadora valoriza a linguagem, permitindo-lhe iniciar e manter interações sociais (Sim-Sim, Silva \& Nunes, 2008), parece reconhecer também que as crianças precisam de interações amplas e continuadas com adultos significativos (Katz, 2006) valorizando interações enriquecedoras e envolventes, mas, simultaneamente, transparece a ideia contraditória de que as crianças (ainda) não são vistas como construtoras de um modelo do mundo, e como alguém capaz de encontrar sentido para as experiências, através da conversa ou da troca de palavras ou discussão de ideias com outros.

Ao narrarem as suas experiências pedagógicas, recorrentemente as professoras realizam um processo de distanciamento no sentido de procurarem analisar os seus 
posicionamentos, mostrando que a reação das crianças direciona ou influencia a ação profissional, como nos conta a Elizabeth: "Apesar de ser um grupo agitado e com a necessidade da intervenção do adulto em muitas das situações de conflito, as ocorrências dentro da sala diminuíram e o facto de registarem no 'Diário' para depois se discutir na reunião de 'Conselho', ajuda na sua gestão. A minha esperança de conseguir regular alguns comportamentos menos apropriados não se esgotou e conto com as reuniões de conselho para esta árdua tarefa". Neste caso, apoiar aprendizagens holísticas e diversificadas, com uma abordagem positiva do erro e com questionamento, parece ajudar a construção da ideia da participação e de vivências democráticas que permite a escuta atenta da criança e que ela aprenda a escutar o outro, portanto, uma construção de aprendizagens mutuas e em comunidade. No fundo, a participação de vários autores que vai possibilitando a ampliação e negociação de significados, assim como a reflexão, anotada como prática pedagógica de qualidade em Folque, Leal da Costa \& Artur, 2016.

Nas narrativas recolhidas surgem muitas reflexões que evidenciam as preocupações com as dificuldades que os pais manifestam em atender adequadamente os seus filhos, com reflexos irrefutáveis na interação pais-filhos e pais-professores: "(... ) porque as pessoas não têm tempo, os pais não têm tempo, não estão disponíveis para os ouvir(...) eles têm necessidade de falar, de escrever às vezes... (...) Quando o relacionamento, por exemplo, de um familiar não está bem, quando há problemas entre os pais, eles sofrem imenso (...)" (Maria, 1Cc).

As alterações a nível das tipologias e dinâmicas familiares encontram-se muito presentes nas narrativas, mobilizadas como muito pertinentes na diferença de interações que se estabelecem e da influência dessas interações nas representações e práticas profissionais: "Ao mesmo tempo que o número [de tipo de famílias] aumenta, o que é dramático, é que cria perante eles uma igualdade, um paralelismo em que eles sentem, se Ihes possibilitarmos, partilharem. Dizem, por exemplo: "Eu já sou igual à Maria, porque à Maria por vezes já Ihe aconteceu a mesma coisa" (...) eles próprios depois conseguem encaixar-se no contexto, o que passa, quase, a ser normal (...) há um padrão por eles reconhecido, na minha opinião que se está a criar, mas onde eles se integram e não se sentem sozinhos" (Dulce, El). Neste 'o que é dramático', a Educadora revela o seu posicionamento face a alterações sociais a ocorrerem, obrigando-a a repensar as suas interações no reconhecimento de como a aceitação das novas tipologias familiares se justifica pelo facto de a normalização da aceitação destas situações conferir segurança às crianças. Por outras palavras, parece-nos evidente que estas docentes, quer em Jardim de infância, quer no $1^{\circ}$ Ciclo, assumiram o risco de escutar a voz das crianças, pondo em causa práticas e conceções antes não questionadas, com a habilidade de aprender "a partir de diferentes pontos de vista e, portanto, de dar um salto em frente na emergência de uma nova cultura - uma cultura de aprendizagem" (Correia, Caldeira, Paes, Micaelo \& Vitorino, 2002, p. 24).

As identidades profissionais obrigam a analisar processos de construção social 
contingentes, que se articulam com o tempo e as circunstâncias, na diferenciação e na generalização (Dubar, 1991; Sarmento, T. 2009, 2015), o que nesta dimensão, dada a complexidade das interações exigidas, se torna muito premente e edificante. $\mathrm{Na}$ narrativa sobre um processo de formação coletivo entre educadoras, muito baseado na socialização da reflexão sobre práticas pedagógicas, é manifesto o interesse desta forma de construir conhecimento para a formação pessoal/profissional, como nos diz Júlia (EI), "Com a riqueza das partilhas aprendemos a mudar o nosso olhar, a apurar a nossa sensibilidade".

Giroux (1998) defende que os professores são intelectuais críticos e transformadores, que buscam na formação teórica e na reflexão sobre a sua experiência as respostas para as questões que se levantam no quotidiano. Enquanto intelectuais críticos e transformadores, os professores exercem "[...] ativamente a responsabilidade de propor questões sérias a respeito do que eles próprios ensinam, sobre a forma como devem ensiná-lo e sobre os objetivos gerais que perseguem" (Giroux, 1998, p.176); ou seja, para além ou mesmo antes dos conteúdos académicos, os professores de crianças pequenas, aprendem e trabalham a partir da relação que estabelecem com as crianças, as famílias e a comunidade, intervindo pouco a pouco na transformação social.

\section{UMA SÍNTESE, TERMINANDO SEM CONCLUIR}

Terminado este texto é tempo de sistematizar as ideias centrais que procuramos apresentar no mesmo, ou seja:

- os métodos biográficos constituem um método fundamental para o acesso ao conhecimento sobre identidades profissionais de professores, a sua forma de construção e de desenvolvimento profissional, a epistemologia dos seus saberes, os significados que os mesmos atribuem às interações que ocorrem ao longo das suas trajetórias;

a investigação em rede, sustentada na pesquisa biográfica, amplia as oportunidades de conhecimento de um maior número de histórias de vida, de que resulta a complexificação das abordagens analíticas, garantindo a formação aprofundada das próprias investigadoras e maior segurança na afirmação deste paradigma no mundo académico;

. o projeto "O que fazemos com o que fazem connosco...identidades profissionais em (re)construcã", desenvolvido por investigadoras portuguesas e brasileiras, tem permitido focalizar a análise sobre as identidades profissionais, seja pela abordagem de diferentes dimensões em separado (formação, interações, organização educacional,...), seja pela abordagem caleidoscópica das suas articulações;

- a abordagem específica das interações de professores com crianças permite desocultar algumas ambiguidades entre discursos apologistas da relevância das interações horizontais criança-adulto, com reconhecimento da agência das crianças 
e, por outro lado, descrições de práticas em que a ação está concentrada no adulto, mantendo-se a criança como simples respondente;

. ao mesmo tempo, as narrativas manifestam propósitos e princípios educativos na defesa do bem-estar e do incremento dos direitos das crianças;

. é possível também desvendar transições ideológicas nas professoras quando partem de um modelo ideal de família e de sociedade conotadas com as suas infâncias e as realidades diversas com que se confrontam atualmente, o que as leva a repensar as suas interações com as famílias das crianças de que são responsáveis e as práticas pedagógicas que desenvolvem;

. nesta análise fez-se sentir a necessidade de profundo e continuado conhecimento dos contextos de prática profissional para acompanharmos, realmente, atuais e futuros docentes, assim como apelos ao reforço de sinergias de cooperação entre docentes da universidade, docentes das escolas, futuros professores e contextos - um tecer da formação e da transformação;

- percecionando que investigação e docência na universidade podem igualmente tomar os contornos de uma construção partilhada, quando com os outros entrelaçamos memórias, vivências e subjetividades num trabalho comunicativo com construção de sentidos, compreendemos que trabalhar na formação de professores nos tem permitido, de alguma forma, operacionalizar a significação do cuidar e acompanhar enquanto dimensões estruturantes no desenvolvimento humano. No fundo, a nossa atividade com professores, ao desocultar processos pelos quais a vida quotidiana foi acontecendo, deixa-nos inscrever uma certa dimensão operatória do conceito de cuidado na prática profissional educativa e afirmar que pode ser também projetar, valorizar memórias, saber escutar e aprender em conjunto. Certamente foi não silenciar conexões entre conhecimentos que se narraram e o que se viveu, favorecendo a apreensão de especificidades que se exprimiram nos atos de viver e de narrar.

- a curiosidade que nos moveu inicialmente, levando-nos a focar a identidade profissional como objeto de estudo, mais propriamente a sua (re)construção utilizando a via da investigação biográfica com entrevistas narrativas por ser a que considerámos mais adequada, levou-nos a nós, formadoras de professores e investigadoras, a uma busca de sentidos para a ação profissional na universidade e o papel a assumir nas duas vertentes. Garantidamente, esta tem sido uma oportunidade para afirmarmos valores intrínsecos da pesquisa biográfica - "ao mesmo tempo, a agentividade individual e a estrutura social, a experiência singular e os "quadros da experiência", a "sociedade vivida" e a "sociedade constituída" (Delory-Momberger, 2016, p. 141).

Por fim, a participação em processos de investigação colaborativos, motivanos enfim, enquanto docentes e investigadoras, a continuar esta caminhada, a questionarmos saberes inacabados. Enfim, um caminhar para nós na certeza de que "A viagem não começa quando se percorrem distâncias, mas quando se atravessam as nossas fronteiras interiores" (Mia Couto, "O outro pé da sereia", 2006). 


\section{REFERÊNCIAS BIBLIOGRÁFICAS:}

BERTAUX, D. Les récits de vie. Paris : Ed. Nathan. 1997.

BOLTANSKI, L. Les cadres - la formation d'un groupe social. Paris: Les Editions de Minuit. 1982.

COHEN, L. e MANION, L. Métodos de Investigación Educativa. Madrid: Muralla. 1990.

CONNELY, F. M., \& CLANDININ, D. J. Teachers as Curriculum Planners - Narratives of Experience. New York: The Ontario Institute for Studies in Education and Teachers, Columbia University. 1988.

CONNELY, Michael \& CLANDININ, Jean. Stories of experience and narratives inquiry. Educational Researcher, 14(5), 2-14. 1990.

CORREIA, Ana, CALDEIRA, Elsa, PAES, Isabel \& VITORINO, Teresa. As vozes dos alunos: os alunos como colaboradores no processo de melhoria da escola. Revista Inovação, 15 (1/3), 261-283. 2002.

COUTO, Mia. O outro pé da sereia. São Paulo: Companhia das Letras. 2006.

DELORY-MOMBERGER, Christine. A pesquisa biográfica ou a construção partilhada de um saber do singular. Revista Brasileira de Pesquisa (Auto)Biográfica, V1-1, n¹, 133-147, 2016.

DUBAR, Claude. La Socialisation - construction des identités sociales et professionnelles. Paris : Armand Colin.1991.

DUBAR, Claude. La socialisation. Dictionnaire encyclopédique de l'éducation et de la formation, 974-977. 2000.

FERRAROTTI, F. Sobre a Ciência da Incerteza: o método biográfico na investigaçã em Ciências Sociais. Mangualde: Ed. PEDAGO. 2013.

FOLQUE, Assunção, LEAL DA COSTA, Conceição \& ARTUR, Ana. A formação inicial e desenvolvimento profissional de educadores/professores monodocentes: os desafios do isomorfismo pedagógico. In Carlos Humberto Alves Correa, Luciola Inês Pessoa Cavalcante \& Michelle de Freitas Bossoli (org.). Formação de Professores em perspectiva. Universidade Federal do Amazonas, pp. 177-236. Manaus: EDUCA. 2016.

GIROUX, Henry. Os professores como intelectuais: rumo a uma pedagogia crítica da aprendizagem. Porto Alegre. Artes Médicas. 1998.

JOSSO, M. Experiências de vida e formação Experiências de vida e formação Experiências de vida e formação. Lisboa: Educa. 2002.

KATZ, Lilian. Perspectivas atuais sobre aprendizagem na infância. Saber e educar, 11. pp. -7-21. 2006.

LEAL DA COSTA, C. "Viver construindo mudanças - a vez e a voz do professor. Contributo para os estudos da aprendizagem e desenvolvimento dos professores". Doutoramento em Ciências da Educação, Universidade de Évora. 2015.

LEAL DA COSTA, Conceição \& CAVALCANTE, Isabel. Alteridades(s), escritas de si e reflexão olhares cruzados sobre formação de professores em Portugal e no Brasil. Revista Brasileira de Educação de Jovens e Adultos, 25 (10), 108-126. 2017.

LEAL DA COSTA, Conceição \& NUNES, Sandra. Tornar-se Educadora/Professora - palavras que contam como foi! Revista da FAEEBA - Educação e Contemporaneidade, Salvador, 25 (47), 119136. 2016. 
MARCELO, Carlos. O professor iniciante, a prática pedagógica e o sentido da experiência. in Formação docente, 2 (3), 11-49, 2010.

MONTERO, L. A construção do conhecimento profissional docente. Lisboa: Horizontes Pedagógicos. 2005.

NÓVOA, A. (coord.). Os professores e sua formação. Lisboa. Publicações Dom Quixote, Portugal, 1992.

NÓVOA, António. «Para uma formação de professores construída dentro da profissão». www. revistaeducacion.mec.es/re350/re350_09por.pdf. Acessado em 31-03-2016, 2009.

NÓVOA, António. Firmar a posição como professor, afirmar a profissão docente. Cadernos de Pesquisa, v.47, $n^{\circ} 66, \mathrm{pp} 1106-1133.2017$.

POIRIER, Jean; CLAPIER - VALLADON, Simone; RAYBANT, Paul. Histórias de Vida - Teoria e Prática, Oeiras, Celta Editora. 1995.

PRAMLING e JOHANSSON. Play and learning -inseparable dimensions in preschool practice. Early Child Development and Care, Volume 176, p.47.65, 2006.

ROLDÃO, Mª Céu. Revista Brasileira de Educação, v.2, n³4, pp 94-103. 2007.

ROLDÃO, $M^{a}$ Céu. Conhecimento, Didáctica e Compromisso: o triângulo virtuoso de uma profissionalidade em risco. Cadernos de Pesquisa, vol.47, nº 166, pp. 1134-1149. 2017.

SARMENTO, Teresa. Contextos de Vida e Aprendizagem da Profissão. Formosinho, J. (Org.), Sistemas de Formação de Professores: Saberes Docentes, Aprendizagem Profissional e Acção Docente. Porto: Porto Editora, pp.303-327. 2009.

SARMENTO, Teresa. Formação de Professores para uma Sociedade Humanizada. Revista da Educação. PUC-Camp., Campinas, 22(2):285-297. 2017.

SARMENTO, Teresa. Histórias de Vida de Educadoras de Infância. Lisboa: IIE. 2002.

SARMENTO, Teresa. Identidades profissionais e contextos de trabalho na educação de infância. In Educação de Infância: formação, identidades e desenvolvimento profissional, Ferreira, $\mathrm{F} \mathrm{e}$ Anjos, Cleriston (Org.), Maceió: De Facto Editores, pp 69-86. 2015.

SARMENTO, Teresa. Infâncias e crianças em narrativas de educadoras de infância. in Pesquisa (auto)biográfica, infâncias, escola e diálogos intergeracionais, Passeggi, Furnaletto e Palma (Org.) (pp.77-94). Curitiba: Editora CRV. 2016.

SEVERINO, A. A busca do sentido da formação humana: tarefa da Filosofia da Educação. Educação e Pesquisa. V.32 n.3 São Paulo. 2006.

SIM-SIM, Inês, SILVA, Ana Cristina \& NUNES, Clarisse. Linguagem e Comunicação no jardim de infância. Lisboa: Ministério da Educação. 2008. 


\section{O CONCEITO DE MEDIAÇÃO NA PSICOLOGIA HISTÓRICO-CULTURAL NA COMPREENSÃO DOS PROCESSOS DE APRENDIZAGEM}

Ludynnylla Paiva Botta dos Passos UNESP -Faculdade de Ciências e Letras Araraquara, São Paulo

Marcia Cristina Argenti Perez UNESP -Faculdade de Ciências e Letras

Araraquara, São Paulo

RESUMO: O presente artigo desenvolve um estudo teórico de levantamento e análise de textos de autores clássicos e contemporâneos da Psicologia Histórico-Cultural que versam sobre o conceito de mediação e a importância da atitude mediadora no processo de aprendizagem. Verificamos que a mediação é um processo que explica a relação do homem com o mundo e com outros homens. Este processo envolve a mediação do homem e mundo por meio de instrumentos e sistemas de signo que só os homens são capazes de criar no contexto histórico, social e cultural. Em suma, o aprofundamento da análise teórica de alguns estudos clássicos e contemporâneos da Psicologia Histórico-Cultural permitiu a compreensão do conceito de mediação e a relevância do aprendizado mediado como aspecto necessário e universal do processo de desenvolvimento das funções psicológicas culturalmente organizadas e especificamente humanas.

PALAVRAS-CHAVE: Mediação. Aprendizagem.
Psicologia Histórico-Cultural.

ABSTRACT: This article develops a theoretical study of the study and analysis of texts of classic and contemporary authors of HistoricalCultural Psychology that deal with the concept of mediation and the importance of the mediating attitude in the learning process. We find that mediation is a process that explains the relationship of man to the world and to other men. This process involves the mediation of man and world through instruments and systems of sign that only men are able to create in the historical, social and cultural context. In short, the deepening of the theoretical analysis of some classic and contemporary studies of Historical-Cultural Psychology allowed the understanding of the concept of mediation and the relevance of mediated learning as a necessary and universal aspect of the process of development of culturally organized and specifically human psychological functions.

KEYWORDS: Mediation. Learning. HistoricalCultural Psychology.

\section{INTRODUÇÃO}

A discussão do conceito de mediação para compreensão dos processos de aprendizagem representa uma sensível transformação em relação à compreensão da função social, diante 
disso Vigotski (2007) afirma que: "assim, a noção de zona de desenvolvimento proximal capacita-nos a propor uma nova fórmula, a que o "bom aprendizado" é somente aquele que se adianta ao desenvolvimento".

Por meio de uma perspectiva Vigotskiana, a apropriação do conhecimento está diretamente relacionada à mediação entre sujeito/sujeito e sujeito/objeto.

O presente estudo tem como objetivo desenvolver um estudo teórico de levantamento e análise de textos de autores clássicos e contemporâneos da Psicologia Histórico-Cultural que versam sobre o conceito de mediação e a importância da atitude mediadora no processo de aprendizagem. A pesquisa foi realizada por meio de pesquisa bibliográfica que, segundo Severino (2015), permite o contato com documentos impressos, como livros, artigos, teses etc., tornando-se fontes do tema a ser pesquisado.

Trata-se de uma pesquisa teórica de levantamento e análise de autores clássicos e contemporâneos da Psicologia Histórico-Cultural que versam sobre o conceito de mediação e os processos de aprendizagem.

\section{RESULTADOS E DISCUSSÃO}

A psicologia Histórico-Cultural tem suas bases epistemológicas, fundamentadas no Materialismo Histórico-Dialético, para Souza (2007) o ponto inicial metodológico do Materialismo Histórico-Dialético é a possibilidade do conhecimento e compreensão da própria realidade social, do conhecimento do real em si. Logo, a realidade social pode ser compreendida por meio da razão humana, visto que a realidade social pode ser conhecida porque resulta da atividade sensorial humana, pois é o produto da práxis humana objetivada.

Os seres humanos se distinguem dos animais somente quando começam a produzir os seus meios de vida, quando ele começa a modificar a natureza, por exemplo, instrumentos para caçar animais, ele transforma a natureza através do trabalho.

O trabalho é a atividade que impulsiona o desenvolvimento humano, o trabalho é o núcleo da atividade criadora do sujeito humano. De acordo com a perspectiva marxista, Leontiev (1978b) destaca que os homens se formam no processo de trabalho, no qual produzem os meios necessários para a satisfação de suas necessidades, biológicas e outras mais complexas geradas nas relações sociais.

Souza (2007) afirma que para o Materialismo Histórico-Dialético o conceito ou a concepção de homem supõe a superação da condição animal, ou seja, superação de um ser irracional, no qual age em função das necessidades imediatas e se guia pelos instintos, passando para um ser (homem) capaz de antecipar, planejar em sua mente os resultados de suas ações, é capaz de escolher os caminhos que vai seguir para alcançar seus fins. 
Assim, o modo de produção é o modo como os humanos produzem e reproduzem seus meios de sobrevivência, através do trabalho e da cooperação. Estes se tornam necessidades humanas com o desenvolvimento histórico da sociedade. Porém, a forma de organização do trabalho e da cooperação nas sociedades divididas em classes é feita por meio da divisão social do trabalho (MARX ; ENGELS, 1998). (Souza, 2007, s/n)

No entanto, a divisão social do trabalho que produz a distribuição desigual do excedente econômico gerado socialmente, gera as classes sociais antagônicas.

Esta breve exposição sobre o Materialismo Histórico-Dialético nos encaminha para a compreensão do homem como sujeito histórico, se faz necessário compreendermos como Vigotski (1896-1934) constituiu seus estudos, tendo como princípio uma Psicologia Histórico-Cultural.

Leontiev (1978b) afirma que o psiquismo humano é determinado pelas relações do homem com o mundo, e essa por sua vez, dependem das condições objetivas da vida. Buscou entender o desenvolvimento histórico do psiquismo humano, tentando entender a reorganização dos processos psíquicos no decorrer da evolução histórica e ontogênica e destacou que as condições que deram forma ao processo de hominização e a passagem à consciência foram às relações da ação do homem sobre a natureza. O nosso pensamento é mediado pela cultura e a linguagem é o principal meio desta mediação.

Além dos indivíduos se objetivarem nos objetos materiais e não materiais através de sua atividade social e histórica, os indivíduos têm que se apropriar da cultura já acumulada.

O desenvolvimento cultural constitui-se na atividade humana mediada pelas relações e pelas objetivações humanas, social e historicamente produzidas. Portanto, a criança é sujeito do conhecimento, considerando sua atividade na cultura, dadas as condições objetivas deste mundo que a permite interiorizar as qualidades humanas ali presentes.

Segundo Vigotski (2007), mediação é o processo que caracteriza a relação do homem com o mundo e com outros homens. Sendo assim ele mediatiza, regula e controla este processo pela sua atividade. Esta relação com o mundo é mediada por instrumentos e sistemas de signo que só os homens são capazes de criar, são ferramentas auxiliares da atividade humana, que se entrepõem o sujeito e o objeto de sua atividade em busca de novas aprendizagens e consequente desenvolvimento (FACCI, 2004).

Facci (2004) destaque que os processos mediados agem junto às funções psicológicas superiores, tais como a atenção voluntária, memória, abstração, "são produtos da atividade cerebral, têm uma base biológica, mas, fundamentalmente, são resultados da interação do indivíduo com o mundo, interação mediada pelos objetos construídos pelos seres humanos".

Souza (2007) afirma que com base no Materialismo Histórico-Dialético, Vigotski 
estendeu o conceito de mediação que se estabelece entre o homem e seu ambiente por meio do uso de instrumentos (ferramenta), para o uso de signos (a palavra, a escrita, dentre outros), compreendendo que, da mesma maneira como os instrumentos são criados pela cultura ao longo da história, a internalização dos signos produzidos culturalmente modifica o comportamento, e provoca a ligação entre as formas elementares e as superiores do desenvolvimento psíquico no homem.

Os signos ou instrumentos estabelecem elementos essenciais na formação e no funcionamento da consciência. Leontiev (1978b), afirma que apropriando-se dos modos de cultura, o homem reproduz as qualidades tipicamente humanas, historicamente formadas.

Para Souza (2007), a criança aprende com o outro mais experiente por meio da mediação, e se apropria dessas qualidades humana, e cita que para Leontiev (1995), "a principal característica do processo de apropriação [...] é, portanto, criar no homem aptidões novas, funções psíquicas novas" (p. 270).

O processo de objetivação e apropriação das qualidades humanas pressupõe uma mediação entre o sujeito e a cultura. $O$ desenvolvimento cultural do homem acredita na sua interação constante com o meio natural, uma troca entre eles. Dessa forma, a interação permite que o homem transforme a natureza.

A educação orientada à criança modifica seu psiquismo e cria nela possibilidades de aprendizagens, primeiro por meio das relações e atividades mediadas com o mundo que a rodeia, e segundo, como atividade interna, psíquica, que o processo de apropriação adquire.

Martins e Moser afirmam, que se toda ação humana é mediada, a aprendizagem se faz com a mediação semiótica ou pela interação com o outro, na interação social, onde fazemos uso das palavras como meio de comunicação ou de interação.

Segundo Martins e Moser (2012), Vigotski e Leontiev, consideram os conceitos de "meios mediacionais" e de "ação mediada" sendo essenciais para compreender o verdadeiro significado do processo de aprendizagem.

\footnotetext{
Se falarmos de meios, significa que o acesso do homem ou de sua mente ao mundo não se da de modo direto, mas por uma mediação que lhe permite um acesso indireto. Lembrando o triângulo do significado de Ogden e Richards (1976), a passagem da coisa ou do objeto à palavra não se dá de maneira direta, mas por meio do conceito. E o conceito envolve a mediação das interações e interconexões neuronais (a passagem dessas interconexões à consciência em que se produz o conceito é outra questão, que, aliás, está em aberto). (Martins e Moser, p.11).
}

Para Vigotski, os conceitos são formados pela mediação de signos, e a linguagem passa a ser o meio mais importante que os seres humanos possuem para formar conceitos e para aprender, sempre no contexto da interação social.

Para Souza (2007), a mediação pode ser considerada o elo entre a atividade da criança e seu meio. E o grande protagonista desta mediação é o educador, o qual pode provocar na criança os motivos para o desenvolvimento das características 
essencialmente humanas.

A grande responsabilidade dos educadores encontra-se no desenvolvimento dos alunos através da aprendizagem que se dará pela mediação, e deve respeitar os conhecimentos que os alunos carregam consigo, o professor deve mediar estes conhecimentos e eleva-los para outros níveis de conhecimento.

\section{CONSIDERAÇÕES FINAIS}

Em suma, é possível concluir pelo aprofundamento da análise de alguns estudos clássicos e contemporâneos da Psicologia Histórico-Cultural que o aprendizado mediado é um aspecto necessário e universal do processo de desenvolvimento das funções psicológicas culturalmente organizadas e especificamente humanas.

A grande responsabilidade dos educadores encontra-se no desenvolvimento dos alunos por meio da aprendizagem que se dará pela mediação, considerando os conhecimentos que os alunos carregam consigo, os processos sistematizados de práticas mediadas do professor, almejando a elevação das funções psíquicas e de outros níveis internalização do conhecimento.

\section{REFERÊNCIAS}

FACCI, Marilda Gonçalves (2004). A periodização do desenvolvimento psicológico individual na perspectiva de Leontiev, Elkonin e Vigostski. Cad. Cedes, Campinas, vol. 24, n.62, p.64-81.

LEONTIEV, Alexei. 1978a. O desenvolvimento do Psiquismo. (Livro: O desenvolvimento do psiquismo na criança, p.286-313).

LEONTIEV, Alexei. 1978b. O desenvolvimento do Psíquismo. Lisboa; Editora Livros Horizonte. (O homem e a cultura, p. 262-284).

LEONTIEV, Alexei. 1988. Linguagem, desenvolvimento e aprendizagem. (Os princípios psicológicos da brincadeira pré-escolar, p.119 - 142).

LÜDKE, Menga; ANDRÉ, Marli E. D. A. Pesquisa em educação: abordagens qualitativas. 2. ed. Reimpressão. Rio de Janeiro: E.P.U., 2015.

MARTINS, Onilza Borges; MOSER, Alvino. Artigo - Conceito de mediação em Vygotsky, Leontiev e Wertsch. Revista Intersaberes I vol. 7 n.13, p. 8 - 28 I jan. - jun. 2012 IISSN 1809-7286.

SEVERINO, Antônio Joaquim. Metodologia do trabalho científico. 23. ed. rev. e atual. - São Paulo: Cortez, 2007.

SOUZA, Maria Cecília Braz Ribeiro de. Tese - A concepção de criança para o enfoque HistóricoCultural. 2007

VIGOTSKI, L. S. A construção do pensamento e da linguagem. São Paulo: Martins Fontes, 2001. (Capítulo 5 - Estudo experimental do desenvolvimento dos conceitos. Capítulo 6 - Estudo do desenvolvimento dos conceitos científicos na infância).

VIGOTSKI, Lev Semenovich. A formação social da mente: o desenvolvimento dos processos psicológicos superiores. São Paulo; Livraria Martins Fontes Editora Ltda., 2007. 
VIGOTSKI, Lev Semenovich. Linguagem, desenvolvimento e aprendizagem. (Aprendizagem e desenvolvimento intelectual na idade escolar. 2. ed. São Paulo: Ícone, 1988. p. 103-117) 


\section{A PROFISSIONALIZAÇÃO DOCENTE EM TEMPOS DE WEB 2.0 - UMA PROPOSTA DIDÁTICO-PEDAGÓGICA}

Nadia Sanzovo

Mestre em Educação pela UNESP/MaríliaSP. Doutoranda em Ciências da Educação na Universidade de Trás-os-Montes e Alto Douro Vila Real- Portugal. Professora do Departamento de Humanas e Chefe do Departamento de

Educação - DEPED/UTFPR-PB. Participante do Grupo de Pesquisa em Educação, Ciência e Tecnologia - GPECT. E-mail: sanzovo@utfpr.edu.

br

Joaquim José Jacinto Escola

Doutor em Educação pela Universidade de

Trás-os-Montes e Alto Douro. Professor da Universidade de Trás-os-Montes e Alto Douro e do programa de mestrado e do doutorado na linha de pesquisa Filosofia da Educação e Espaço Público,

professor da Escola Superior de Educação de Torres Novas e professor assistente visitante na Faculdade de Letras da Universidade do Porto. E-mail: jescola@utad.pt.

RESUMO: A profissionalização de professores para a nova realidade em tempos de WEB 2.0 tem sido crítica e não tem encontrado ressonância de maneira efetiva pelas políticas públicas em educação nem pelas universidades, cujas propostas inserem-se, principalmente, em programas de formação de nível de pósgraduação ou como programas de qualificação de recursos humanos. O texto apresenta uma proposta, por meio de uma alternativa metodológica, na modalidade de metodologia ativa e colaborativa, com apoio do Laboratório Virtual (Moodle), com o conteúdo organizado, num modelo de intersecção e interação, utilizando as tecnologias de informação e comunicação, para criar serviços que dão suporte ao ensino e à aprendizagem.

PALAVRAS-CHAVE: Sociedade da Informação e do Conhecimento. Contexto digital. Formação profissional. Proposta didático-metodológica.

ABSTRACT: The professionalization of teachers for the new reality in times of WEB 2.0 has been critical and has not found effective resonance in public policies in the educational field and in universities, whose proposals are mainly inserted in graduate programs or in qualification programs for human resources. The article presents a proposal, through a methodological alternative, in the modality of active and collaborative methodology, with the support of a Virtual Laboratory (Moodle), with organized content, in an intersection and interaction model, using information and communication technologies, in order to create services that support teaching and learning processes.

KEYWORDS: Information and Knowledge Society. Digital context. Professional training. Didactic-methodological proposal. 


\section{I INTRODUÇÃO}

Não são poucas as políticas educacionais na América Latina assim como no Brasil no sentido de possibilitar a formação dos professores - os atores fundamentais num contexto de mudanças e novas demandas no contexto atual das sociedades. No entanto, no decorrer dos anos, muitas dessas mudanças têm mostrado fragilidades no que se refere à formação inicial e continuada dos professores, como bem mostram estudos de Gatti, (2003), Gatti e Nunes (2009) e Gatti e Barreto (2009).

Os professores se encontram no centro das preocupações e das políticas educacionais dos países, principalmente, nos ditos países em desenvolvimento. Destarte, críticas têm sido direcionadas ao modelo de formação das faculdades/ universidades em que o professor foi e continua a ser formado, isto é, num modelo essencialmente instrumental de racionalidade técnica - o que também acaba por afastar a pesquisa acadêmica da prática pedagógica e ainda negando-lhes os saberes, inclusive de experiência.

Como docente há mais de vinte anos da Universidade Tecnológica Federal do Paraná, Campus Pato Branco e participante, na chefia, do Departamento de Educação - DEPED, da Instituição, temos, juntamente com a equipe, buscado formas e alternativas de formação continuada para e com o corpo docente de modo a proporcionar um processo ensino-aprendizagem de mais qualidade e comprometido com a formação do estudante exigido no contexto do século XXI.

Este texto é parte da tese de doutoramento de título "Laboratório virtual e modelo multiplicador por grupo: perspectivas para o desenvolvimento de competências profissionais, utilizando as tecnologias de informação e comunicação, na formação de professores", que está sendo desenvolvido no programa de mestrado e do doutorado na linha de pesquisa Filosofia da Educação e Espaço Público, área de Ciências da Educação, da Universidade de Trás-os-Montes e Alto Douro, Vila Real-Portugal.

O objetivo desta proposta é testar um Laboratório Virtual, com utilização das TIC (e-book - Objetos de Aprendizagem), por meio de metodologia ativa (Flipped Classroom e Metodologia Colaborativa - Trezentos (FRAGELLI, 2015) para a Formação Continuada de Professores nos cursos de Bacharelado, por meio de um Modelo Multiplicador por Grupo, focado no desenvolvimento de competências profissionais, tendo por suporte teórico a teoria da ação-reflexão-ação proposta por Schön (1983).

\section{I A PROFISSIONALIZAÇÃO DOCENTE}

Muitos estudos que tratam da formação de professores, na perspectiva de Imbernón (2010), abordam uma fase mais experimental em detrimento de uma fase descritiva em função da difusão dos cursos de formação e, em função desses condicionantes, nos últimos anos tem-se disseminado programas de formação de 
professores e, por isso,

[...] la idea de que el sostén puramente 'experiencial' de la práctica educativa escolar de la mayor parte de los profesores estaría en la raíz de su ineficacia. A partir de aquí se nos dice que la base científica de las normas pedagógicas es potenciadora de la eficacia docente. Y se considera, siguiendo a M. Bunge, que "una regla es fundada si y solo si se basa en un conjunto de fórmulas de leyes capaces de dar cuenta de su efectividad. (FERNÁNDEZ, 1992:326).

$\mathrm{Na}$ análise feita por vários estudos como de Quartiero; Fantin; Bonilha (2012), mesmo com surgimento de algumas propostas inovadoras de formação, todo investimento na implementação de propostas inovadoras de formação de professores tem apresentado resultados aquém do esperado, de acordo com os Relatórios do Programa Internacional de Avaliação de Alunos (PISA) e da Organização para Cooperação e Desenvolvimento Econômico (OCDE).

De acordo com esses documentos, esses programas têm evidenciado baixos impactos, de modo geral, nas práticas docentes - o que implica uma revisão crítica dos modelos de formação que estão em curso nas políticas educativas, no sentido de que se manifesta uma preocupação acentuada com a formação de professores para que possam atuar melhor no instável mundo globalizado (SACRISTÁN, 1999).

O que tem sido feito em primeiro lugar, segundo autores como Sossai, Lunardi Mendes, Pacheco (2009); Peralta, Costa (2007), é tão somente o "apetrechamento" das escolas, isto é, a aquisição de parafernálias tecnológicas, que em curto espaço de tempo se tornam obsoletas, e só depois a formação dos professores para o uso dessas ferramentas. Mas mesmo assim, pesquisas também apontam que não há mudanças significativas.

De um lado se acredita que as Tecnologias Digitais (TD) aguçam o interesse, a motivação e a criatividade dos alunos, levando a crer que aliadas a propostas metodológicas que valorizam e privilegiam a aprendizagem, por outro lado, professores sem a devida qualificação para atuar com as novas tecnologias não possibilitarão mudanças pedagógicas significativas. No entanto, para uma efetiva integração implica investimentos em dois domínios: na atitude dos professores e numa adequada capacitação para o seu uso (PERALTA e COSTA, 2007).

Muito embora o acesso e a oferta de formação no âmbito das TDIC (Tecnologias Digitais da Informação e Comunicação) tenham aumentado nos últimos anos, a realidade é que na prática - mesmo utilizando mais as TD no seu fazer pedagógico, os tipos e usos têm sido muito redutores em termos do seu verdadeiro potencial (LUNARDI-MENDES e outros, 2013).

Assim, segundo García Carrasco (1984, p. LI), citado por Fernandez (1992:3245), por exemplo, a construção de

[...] proposiciones pedagógicas debiera seguir los siguientes pasos: 1. Algo debe ser conseguido. 2. Existen teorías científicas que pueden ser utilizadas como 
recurso explicativo o de legalidad en el ámbito de hechos comprometidos por las metas propuestas. 3. Determinación de secuencias de acción, os enunciados normativos que rigen secuencias de acción, entre cuyos efectos deben quedar incluidos los propósitos intentados. Momento, este último que, a su entender, se constituye en "criterio validador de las normas pedagógicas y, por lo mismo, en fuente de progreso de la actividad racional en pedagogia.

Autores, como Kochler e Mishira (2008), retomam as ideias de Shulman (1987) e ampliam o conceito específico da utilização das TIC no processo de ensino e aprendizagem, acrescentando ao modelo um terceiro componente: o conhecimento tecnológico, conceituando-o como modelo TPACK, cuja premissa é a ideia de que a atitude do professor no que diz respeito às tecnologias é multifacetada, dinâmica e uma sintonia para a integração das TIC no currículo resultará da interseção balanceada de três tipos de saberes: o conhecimento pedagógico, o conhecimento de conteúdo e o conhecimento tecnológico.

Esse modelo defende a ideia de que o uso da tecnologia no ensino superior requer o desenvolvimento de um conhecimento complexo, contextualizado, denominado por seus autores de Conhecimento Tecnológico e Pedagógico de Conteúdo (CTPC), traduzido dos termos em inglês Technological Pedagogical Content Knowledge - TPACK. O modelo apresenta a ideia de uso pedagógico das TDIC (Tecnologias Digitais de informação e Comunicação) que pode ser possível a um professor capaz de articular e inter-relacionar os três tipos diferentes de conhecimento: (i) Conhecimento de conteúdo ou disciplinar da sua área específica; (ii) conhecimento pedagógico e (iii) conhecimento tecnológico conforme ilustrado na Figura 01.

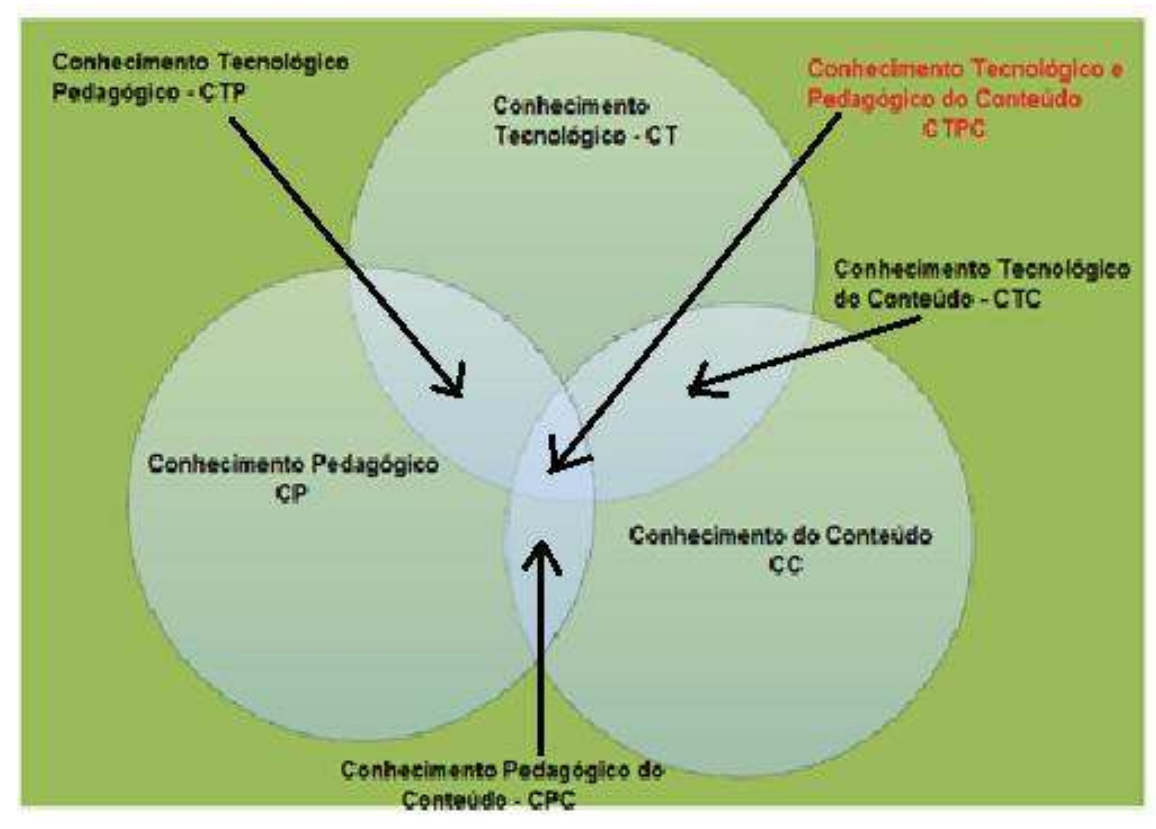

Figura 1 - Modelo TPACK

Fonte: Baseado em Koehler e Mishra (2008)

O conceito de TPACK pode facilitar a compreensão da forma como se processa o 
desenvolvimento profissional de um professor para usar as TDIC no ensino curricular de sua disciplina. Essa justificativa aponta para a aplicação do modelo para atender a um rápido desenvolvimento da cibercultura no contexto atual da sociedade da informação, sustentando a hipótese de que o desenvolvimento desses saberes facilitaria o uso das TDIC nos processos pedagógicos em sala de aula (JONASSEN, 2007).

Destarte, o percurso de formação defendido, neste texto, sustenta que o aprendizado de ofício complexo como o ensino deve compreender, ao mesmo tempo, uma teoria associada à prática decorrente de uma teoria. Tal forma de articular uma proposta implica, então, uma formação continuada; implica, sobretudo, que cada formador suscite em seu próprio meio a emergência de aspectos teóricos ligados às problemáticas vividas pelos professores (BÉLAIR, 2001).

Nesse ponto, os mecanismos de formação estabelecidos para responder a essa conduta, como as contextualizações e as observações que serviriam de modelos a transportar para a sala de aula junto aos alunos, poderiam ser retomados em uma conduta de meta-análise, na qual os professores em serviço refletissem sobre a importância de certos mecanismos após terem vivenciados eles próprios essas ações como aprendizes.

Segundo Paquay (1994, apud BÉLAIR, 2001), o professor pode ser o professorpesquisador, isto é, aquele que analisa a sua prática, coloca questões, reflete e age na ação. Schön (1997) identifica nos bons profissionais uma combinação de ciência, técnica e arte e é nessa dinâmica que possibilita ao professor agir em contextos instáveis como o da sala de aula, principalmente numa cultura tecnológica como a contemporânea. O processo é essencialmente meta cognitiva, segundo o qual, o professor dialoga com a realidade que lhe fala, em reflexão permanente.

Como, então, definir as competências de um professor reflexivo que tem como eixo as necessidades e as demandas de seus alunos e em um ambiente determinado? Como ensinar essas competências que são afinal pouco teorizadas, mais pragmáticas e, em geral, provêm de atitudes? São tantas as questões para as quais não se parecem oferecer verdadeiras propostas (BÉLAIR, 2001), mas para as quais se devem buscar respostas em programas de estudos e pesquisas.

Para Perrenaud et al (2001), cinco campos parecem sugerir uma estrutura que permite a emergência de campos de competências a serem adquiridos pelo novo professor, que lhe possibilitem adequar um percurso de formação a fim de responder as necessidades de formação de uma profissionalização consciente:

- Competências exigidas em relação à sociedade;

- Competências ligadas à vida de classe;

- Competências inerentes a sua pessoa;

- Competências ligadas às disciplinas ensinadas;

- Competências ligadas na relação com os alunos e suas particularidades. 
Esses campos de competências permitem, então, visualizar o percurso a ser desenvolvido. Os professores de ofício devem cobrir todos esses campos de competências de acordo com suas necessidades, suas forças e suas fraquezas, em contexto mais personalizado, no qual os cursos servem de pontos de referências para suas reflexões organizadas de suas práticas em sala de aula. Sem atingir a todos, sobretudo porque seria mais difícil avaliar esses êxitos, o professor deve percorrê-los e prever, conscientemente ou não, um plano de formação pessoal, tendo em vista apropriar-se deles ao longo de sua carreira.

Convém lembrar que a centralidade na intervenção remete ao ator que produz. Não se pode conceber, como lembra Haramein (1991), citado por Carbonneau e Hétu (2001), a interação entre saberes práticos e teóricos sem um ato que a porte. Ou seja, a transformação da prática educativa e do saber do professor está estreitamente ligada à transformação da identidade pessoal e profissional.

Assim, cada professor em serviço deverá enfrentar situações para as quais terá de elaborar suas respostas. No entanto, para maior mobilização do conceito de reflexão na formação de professores é necessário criar condições de trabalho em equipe, comunidades de reflexão e pesquisa, entre os professores - o que sugere espaços para esse crescimento.

Uma via possível consiste em, na formação, colocar os professores em serviço em contato com o caráter relativo das modas pedagógicas e, fazendo isto, com a obrigação de construir cada qual sua identidade profissional e equipar sua caixa de ferramentas em função dessa identidade. Por outro lado, essa identidade é sempre o resultado de um equilíbrio entre esquemas de ação mais ou menos antagônicos e é tanto mais rica quanto mais bebe de fontes diversificadas.

Essa possibilidade visaria, a propósito da profissão do professor, a desenvolver estratégias de pesquisa que permitam desvendar sua prática e, assim, vincular a formação ao exercício do professor.

Nesse sentido, Nóvoa (2009a), pergunta: o que será necessário fazer para dar coerência aos propósitos, materializando na prática o consenso que se vem elaborando em torno da aprendizagem docente e do desenvolvimento profissional? Ele responde que talvez seja possível assinalar três medidas, que estão longe de esgotar as respostas possíveis, mas que podem ajudar a superar muitos dos dilemas atuais para a formação do professor:

- Primeira medida - É preciso passar a formação de professores para dentro da profissão, o que quer dizer que há necessidade de os professores terem um lugar predominante na formação dos seus colegas.

- Segunda medida - É preciso promover novos modos de organização da profissão, o que aponta para a necessidade de promover novos modos de organização da profissão. Grande parte dos discursos torna-se irrealizá- 
vel se a profissão continuar marcada por fortes tradições individualistas ou por rígidas regulações externas, designadamente burocráticas, que se têm acentuado nos últimos anos. A colegialidade, a partilha e as culturas colaborativas não se impõem por via administrativa ou por decisão superior.

- Terceira medida - É preciso reforçar a dimensão pessoal e a presença pública dos professores, o que quer dizer que, apesar dos enormes avanços neste domínio, é preciso reconhecer que falta ainda elaborar aquilo que se tem designado por uma teoria da pessoalidade que se inscreve no interior de uma teoria da profissionalidade.

Schön (1997) propõe, assim, a noção de "prático reflexivo", rompendo com o paradigma objetivista e optando por modelo construtivista existencial, centrado na apropriação e na relação interativa dos atores sociais que produzem essas condutas em situações específicas.

Constituído assim, num curso/programa de formação de professores possibilitamse elementos de reflexão e de ação contextualizados a partir da análise de casos, isto é, a estratégia pesquisa-ação-formação permite propor premissas para uma formação articulada à prática profissional (CHARLIER e HAUGLUSTAIN, 1992 apud CHARLIER, 2001).

A profissionalização, então, segundo Perrenoud (2001), é a capacidade de "capitalizar a experiência de refletir sobre sua prática para reorganizá-la".

Por isso, é necessário aos professores que já atuam profissionalmente uma constante reflexão sobre a prática, de modo que possam produzir conhecimento que levem a mudanças e, consequentemente, à qualidade da educação, ou seja, como Perrenoud (2000) lembra que em italiano se chama "aggiornamento", o que ressalta o fato de que os recursos cognitivos mobilizados pelas competências devem ser atualizados, adaptados a condições de trabalho em evolução". (p.156).

Nóvoa (2009b) aponta também cinco disposições que são essenciais à definição dos professores nos dias de hoje. Elas servem de pretexto para a elaboração das propostas sobre a formação de professores. São propostas genéricas que, devidamente contextualizadas, podem inspirar uma renovação dos programas e das práticas de formação.

1) O conhecimento - de acordo com as palavras do filósofo francês Alain (1986), citado por Nóvoa (2009b), que, para instruir, é necessário conhecer aqueles que se instruem. Talvez. Mas bem mais importante é, sem dúvida, conhecer bem aquilo que se ensina, posto que ninguém pensa no vazio, mas antes na aquisição e na compreensão do conhecimento.

2) A cultura profissional - ser professor é compreender os sentidos da instituição escolar, integrar-se numa profissão, aprender com os colegas mais experientes. É na escola e no diálogo com os outros professores que se aprende a profissão. 
3) O tato pedagógico - é a capacidade de relação e de comunicação sem a qual não se cumpre o ato de educar. E também essa serenidade de quem é capaz de se dar ao respeito, conquistando os alunos para o trabalho escolar;

4) $O$ trabalho em equipe - os novos modos de profissionalidade docente implicam um reforço das dimensões colectivas e colaborativas, do trabalho em equipe, da intervenção conjunta nos projetos educativos de escola;

5) O compromisso social - pode-se chamar-lhe de diferentes nomes, mas todos convergem no sentido dos princípios, dos valores, da inclusão social, da diversidade cultural. Educar é conseguir que a criança/jovem ultrapasse as fronteiras que, tantas vezes, Ihe foram traçadas como destino pelo nascimento, pela família ou pela sociedade.

A proposta, portanto, é pesquisar, analisar o impacto desse espaço de açãoreflexão-ação - Laboratório Virtual para a Formação Continuada de Professores que Ensinam Matemática - por meio do Modelo Multiplicador por Grupo, para construção de um modelo alternativo que possa contribuir na formação e qualificação do profissional.

A tese tem como diferencial desenvolver um modelo alternativo de formação no qual os professores serão os co-construtores do processo. A questão, portanto, é também saber se o professor irá se apossar das tecnologias para mudar de paradigma e concentrar-se na criação, na gestão e na regulação de situações de aprendizagem, posto que ainda há uma distância de gerações, em termos de utilização de tecnologia e o magistério é muito conservador no Brasil.

Assim, neste contexto tecnológico das sociedades contemporâneas, em relação ao professor, Cabero (2001) sinaliza que a influência de novos entornos/contextos tende a uma série de repercussões para ele - professor, no sentido de que modifica e amplia alguns dos papéis que tradicionalmente tem desempenhado, passando a ser: consultor de informação, facilitador de informação, design de medios, moderador e tutor virtual, avaliador contínuo, assessor e orientador. Por outro lado, no contexto da teleformação, o professor também se deparará com três grandes papéis: provedor de conteúdo, tutor e administrador daquilo que cabe ou pertence ao nível organizativo da atividade.

Quando se pensa na utilização de tecnologias educacionais, além de ser necessário o entendimento prévio sobre toda a estrutura para o funcionamento dos recursos, será preciso também desenvolver um plano de utilização das ferramentas e dispositivos que esteja em consonância com o processo pedagógico da escola ou do curso. Para isso, o professor deve entender que as ferramentas serão um ponto de apoio e aprimoramento ao plano de ensino já pré-estabelecido pela instituição.

A utilização das tecnologias agregará valor aos processos de aprendizagem, transformando a dinâmica da sala de aula e o acesso à informação em algo lúdico, estimulante e irrestrito ao ambiente institucional. Como os professores, além dos 
alunos, utilizarão as ferramentas a favor de suas atividades, é preciso que eles sejam convidados a integrar o processo de planejamento para transição e adaptação das rotinas escolares e dos processos avaliativos a essa nova funcionalidade. E para o sucesso dessa mudança, o documento desenvolvido deverá ter como foco a conquista dos objetivos delineados.

Por conseguinte, possivelmente, um dos papéis mais significativos que o professor desempenhará nesses novos contextos será o tutor virtual, papel, segundo Llorente (2006:2) citado por Madrigal (2016), mais amplo do que aquele realizado em uma situação presencial de formação:

[...] el rol que desempeñe el profesor como tutor virtual será fundamental para garantizar la calidad y eficacia del proceso formativo realizado a través de la red. Se puede distinguir cinco roles básicos a desempeñar por los tutores: el rol pedagógico, social, de dirección, técnico y orientador.

Das cinco funções básicas do tutor virtual decorrem:

a) Função acadêmica: (i) Dar informações, explanar e clarificar os conteúdos apresentados; (ii) Supervisionar o progresso dos estudantes e revisar as atividades realizadas; (iii) Responder aos trabalhos dos alunos; (iv) Assegurar que os alunos estão alcançando o nível adequado; (v) Formular perguntas para diagnosticar conhecimentos que os estudantes possuem e levantar as possíveis inconsistências e erros que apresentam; (vi) Construir atividades para facilitar a compreensão de informação e transferência; (vii) Construir atividades e situações de aprendizagem de acordo com um diagnóstico prévio; (viii) Introduzir o tema de debate e relacioná-lo com os anteriores; (ix) Resumir os debates em grupo com aportes dos estudantes; (x) Resolver as possíveis dúvidas surgidas da leitura dos materiais didáticos ou na realização das atividades; (xi) Fazer avaliações globais e individuais das atividades realizadas; (xii) Informar os resultados e avaliações alcançados.

b) Função social: (i) Dar boas-vindas aos estudantes que participam dos cursos em rede; (ii) Facilitar a criação de grupos de trabalho; (iii) Incentivar os estudantes para que ampliem e desenvolvam os argumentos apresentados por seus companheiros; (iv) Integrar e conduzir as intervenções, sintetizando, reconstruindo e desenvolvendo os temas que vão surgindo; (v) Animar e estimular a participação; (vi) Propor atividades para facilitar o conhecimento entre os participantes; (vii) Dinamizar a ação formativa e trabalho em rede; (viii) Facilitar a criação de um ambiente social positivo.

c) Função organizativa: (i) Estabelecer o calendário do curso em geral por módulos, entrega de tarefas e a sequência das diferentes atividades de comunicação; (ii) Estabelecer data e horários para os chats e fórum; (iii) Explicar as normas de funcionamento dentro do ambiente: critérios de 
avaliação, exigências ou nível de participação; (iv) Apresentar as normas de funcionamento para estabelecer contatos com o professor tutor; (v) Manter contato com o restante da equipe docente e organizativa, fazendo chegar rapidamente os problemas detectados em nível de conteúdos, de funcionamento do sistema ou de administração; (vii) Organizar o trabalho em grupo e facilitar a coordenação entre os membros; (viii) Oferecer qualquer informação significativa para a relação com a instituição.

d) Função orientadora: (i) Facilitar técnicas de trabalho intelectual para o estudo em rede; (ii) Dar recomendações públicas e privadas sobre o trabalho e a qualidade do trabalho que está sendo desenvolvido em rede; (iii) Assegurar-se que os alunos trabalhem a um ritmo adequado; (iv) Motivar os estudantes para o trabalho online; (v) Informar os estudantes sobre seu progresso no estudo e facilitar-lhe estratégias de melhores trocas; (vi) Facilitar ações de compromisso quando existem diferenças de desenvolvimento entre os membros das equipes; (vii) Ser guia e orientador do estudante; (viii) Aconselhar o estudante para desenvolvimento de atividades e prosseguimento dos cursos.

e) Função técnica: (i) Assegurar-se de que os estudantes compreendam o funcionamento da plataforma educativa; (ii) Dar conselhos e apoios técnicos; (iii) Realizar atividades formativas específicas; (iv) Fazer gestão dos grupos de aprendizagem que se formam para o trabalho em rede; (v) Incorporar e modificar novos materiais no ambiente formativo; (vi) Remeter aos estudantes partes do programa de onde podem baixar atividades, tarefas, fóruns, entre outras atividades; (vii) Manter-se em contato com o administrador da plataforma; (viii) Conhecer a plataforma e suas ferramentas de trabalho.

Essas funções assinaladas são de grande importância nestes tempos em que a educação virtual vai abarcando espaços cada vez mais importantes nesta sociedade da informação em um mundo em que existem os media para favorecer a interatividade entre as pessoas das diversas nacionalidades, de diversos contextos muitas vezes opostos que permitem ambientes de aprendizagem idôneos, multiculturais, interculturais e internacionais para a construção de aprendizagem significativa e pertinente.

\section{I A PROPOSTA DE REORGANIZAÇÃO DIDÁTICO-METODOLÓGICA}

Nesta proposta apresenta-se o desenho de um possível modelo de formação continuada que engloba tanto os docentes quanto os estudantes numa nova perspectiva para formar o aluno para enfrentar os novos contextos que se colocam na sociedade da informação e do conhecimento.

A proposta de reorganização didático-metodológica aqui apresentada se constitui de: (i) Laboratório Virtual - plataforma Moodle; (ii) Objetos de Aprendizagem (OA); 
(iii) Flipped Classroom (Sala invertida); (iv) Metodologias ativas colaborativas; (v) Ambiente Colaborativo, conforme ilustra a Figura 02.

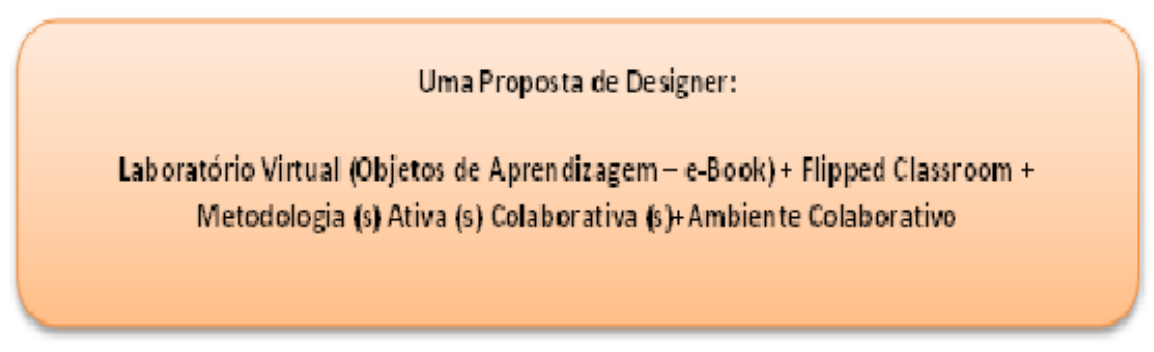

Figura 02 - Proposta de reorganização didático-metodológica

Fonte: Autoria própria

Há, pois, nesta perspectiva, mudança no modelo de comunicação em relação aos modelos unidirecionais de comunicação, onde há um emissor - normalmente o professor ou material didático, que envia ou manda a informação -, e um receptor, normalmente o estudante, que processa e em função de sua semelhança com a apresentada e recebe a qualificação acadêmica.

\subsection{Laboratório Virtual}

O Laboratório Virtual, sustentado e depositado na plataforma Moodle, propõe um modelo de intersecção e interação utilizando as tecnologias de informação e comunicação, para criar serviços que dão suporte ao ensino e à pesquisa, mas mais do que o aporte do recurso tecnológico é a possibilidade de desenvolver uma cultura da autonomia no estudante, posto que a cultura da aula narrativa continua muito forte e arraigada nos nossos sistemas formativos - é preciso, pois, aprender a aprender, desaprender e reaprender na atual sociedade da informação, quando os conteúdos mudam tão rapidamente também.

\subsection{Os Objetos de Aprendizagem (AO)}

Segundo Balbino (2007, p.01),

[...] Objetos de Aprendizagem são definidos como uma entidade, digital ou não digital, que pode ser usada e reutilizada ou referenciada durante um processo de suporte tecnológico ao ensino e aprendizagem. Exemplos de tecnologia de suporte ao processo de ensino e aprendizagem incluem aprendizagem interativa, sistemas instrucionais assistidos por computadores inteligentes, sistemas de educação à distância, e ambientes de aprendizagem colaborativa.

Um bom Objeto de Aprendizagem deve estar dividido em três partes (BETTIO e MARTINS, 2004, p.3): (i) Objetivos: tem como finalidade mostrar ao aprendiz o que ele poderá aprender com o estudo do Objeto. Pode, por exemplo, conter uma lista 
de conhecimentos prévios necessários para um bom aprendizado; (ii) Conteúdo instrucional: mostra todo o material didático que é preciso para que no final o aluno atinja os objetivos dispostos no item anterior; (iii) Prática e feedback: uma característica importante dos Objetos de Aprendizagem é que ao final coloca-se uma avaliação, para que o aluno veja se atingiu às expectativas e, se não, utilizá-lo novamente, quantas vezes forem necessárias.

Assim, nesta proposta, os Objetos de Aprendizagem constituem-se de e-books (Bornatto, Sanzovo, 2017; Machado, Sanzovo, 2017), depositados na plataforma Moodle (o Laboratório Virtual), no endereço:

http://pb.utfpr.edu.br/labvirtual/inicio.html., com o conteúdo determinado para cada disciplina de cálculo, núcleo básico dos cursos.

\section{3 "The Flipped Classroom" - A Sala Invertida}

O método consiste em: (i) fornecer os conteúdos (e-book) com antecedência de forma que os estudantes possam se preparar antes de ir para a sala de aula; (ii) motivar os estudantes a serem protagonistas de sua própria aprendizagem; (iii) mobilizar aulas participativas, com discussões e aplicações práticas. Como vantagens, os defensores apontam uma adequação ao ritmo individual, já que as aulas em vídeo permitem andar, parar e andar para trás. Permitem também a comunicação com colegas e professores, aumentando a motivação; já os que se opõem apontam para uma grande dependência da tecnologia e um reforçar do tempo de ecrã.

Assim, pode-se pensar um currículo misto, ou utilizar-se do expediente da modalidade EAD (Educação a Distância), no caso do "Flipped Classroom" no ensino regular e presencial, o que poderá conciliar as positividades de ambas as modalidades.

\subsection{Metodologia ativa colaborativa}

Em diferentes trabalhos (CABERO e HERNANDES, 1995; CABERO e MARQUEZ, 1997 e 1999), conforme aponta García-Valcárcel (2003), tem-se insistido nas possibilidades educativas que tem o uso dos media pelos alunos como: contextualização dos media e dos materiais de ensino, passar de meros reprodutores/ receptores a produtores de media e à compreensão de seu processo, aprendizagem das linguagens e características técnicas das tecnologias..., sinalizando que sua verdadeira potencialidade educativa não se encontra no produto propriamente dito, mas em todas as atividades que são realizadas no processo.

De outro lado, não se deve esquecer a significação ou significância que a aprendizagem colaborativa está adquirindo com as tecnologias nos últimos tempos. A aprendizagem colaborativa tem recebido diversas conceituações, como se pode observar em Owens (1989), citado por García-Valcárcel (2003) nos seguintes termos: "[...] el intercambio y cooperación social entre grupos de estudientes para el propósito 
de facilitar la toma de decisiones y/lo la solución de problemas. La colaboración entre aprendices les permite compartir hipótesis, enmendar sus pensamentos y trabalhar mediante sus discrepâncias cognitivas".

Sob esta perspectiva, considera-se que a função da educação é mostrar aos estudantes como devem chegar a construir os conhecimentos em colaboração com o restante dos seus companheiros.

\subsubsection{Da Metodologia Colaborativa "Dos Trezentos"}

A utilização de tecnologia de informação e comunicação possibilita desenvolver mecanismos que auxiliam no ensino e aprendizagem em ambientes universitários, como é o caso desta apresentação de uma alternativa metodológica, na modalidade de metodologia colaborativa, com apoio do Laboratório Virtual.

Segundo Fragelli (2015), existem vários fatores que influenciam no baixo índice de concluintes nos cursos de Engenharia tais como a falta de conceitos prévios suficientes para uma aprendizagem significativa, a pouca relação entre o que é ensinado e o mercado de trabalho, e a insistência no modelo tradicional de ensino e aprendizagem que, por diversas vezes, se mostra ineficiente. Também um aspecto muito importante e pouco explorado está relacionado à forma de avaliação da aprendizagem utilizada, principalmente concernente ao nervosismo e à ansiedade que provoca em alguns estudantes.

A metodologia dos Trezentos (FRAGELLI, 2015) consiste, pois, em promover ao máximo a colaboração entre os estudantes, despertando o olhar para as dificuldades de aprendizagem do outro. Nesse sentido, para que essa colaboração seja estimulada, são formados grupos de estudo. Os estudantes realizam uma prova e, com base no resultado dessa avaliação, os grupos são formados pelo professor e contêm, obrigatoriamente, alguns estudantes que tiveram bom rendimento e alguns estudantes que tiveram rendimento considerado insatisfatório.

Os estudantes com rendimento insatisfatório que completarem todas as atividades propostas realizam uma nova prova e ficam com a melhor das duas notas que, quase na totalidade dos casos, é aquela obtida na segunda avaliação. Os estudantes com bom rendimento não podem refazer a prova, contudo, melhoram a própria nota considerando duas dimensões: (a) o nível de ajuda oferecido aos estudantes do grupo; e, (b) a melhora no rendimento dos estudantes ajudados.

As atividades geralmente são as seguintes: (a) dois encontros presenciais com os integrantes do grupo com, pelo menos, duas horas de duração; (b) entrega de uma lista de exercícios desenvolvida pelo professor; e, (c) resolução de uma prova desenvolvida pelo líder do grupo. d) suporte do Laboratório Virtual, com o conteúdo organizado em e-book. 


\subsection{0 ambiente colaborativo}

No entanto, se há todos esses recursos disponíveis, há necessidade de se pensar o desenho de materiais para essa nova ambientação e que não sejam mais aqueles elaborados para serem usados literalmente face a face, ou organizados de modo que os estudantes estejam voltados de costas para os outros conforme o modelo tradicional das salas de aula. O que envolve não somente o ambiente virtual, mas também o ambiente físico da escola regular. Nesta proposta, um dos primeiros passos é conhecer e dominar a plataforma e seus diferentes espaços, como o conteúdo está disposto para o estudante.

Outro aspecto, diferente do presencial tradicional, é a organização que pode ser feita de diferentes formas na sala física para se trabalhar com o material impresso e em hipertexto, com o conteúdo já predisposto. Nessa proposta, na área dos cálculos, as unidades de aprendizagem já estão disponibilizadas para que os estudantes os tenham a sua disposição nos momentos de estudo individualizado, principalmente no modo da "sala invertida" e nos momentos de interação com os colegas do grupo na metodologia ativa colaborativa.

Para tal, propõe-se a "Mesa Heptagonal Separável com Estação Central Multitarefa" (SANZOVO, SILVA, 2017), em vias de patenteamento (Figura 3), como ferramenta, que consiste em uma mesa circular separável que dispõe em sua estrutura central saídas USB e tomadas, oportunizando o uso de eletrônicos e uma estação multitarefa que possibilita uso de computador portátil, sendo a mesma rotativa, viabilizando o aproveitamento em conjunto, cujo desenvolvimento foi realizado em conjunto com uma empresa do ramo metalúrgico e moveleiro.

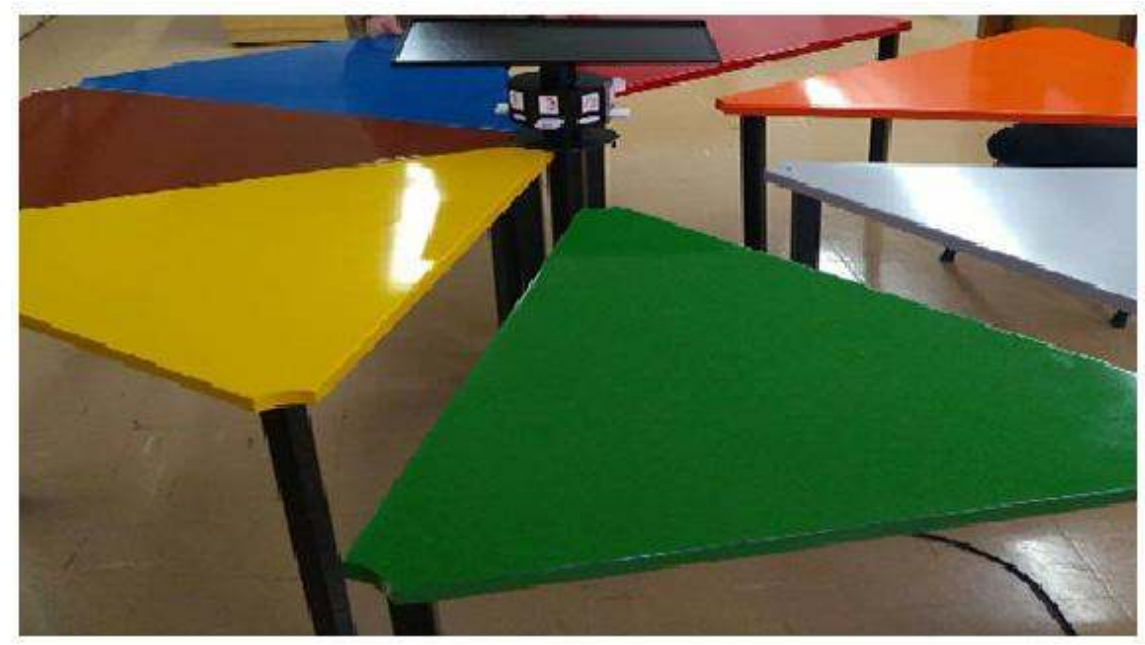

Figura 3 -Mesa Heptagonal Separável com Estação Central Multitarefa Fonte: Sanzovo e Silva (2017) 


\section{I CONSIDERAÇÕES FINAIS}

Esta proposta de desenho didático-metodológico disciplinar, aliando Objetos de Aprendizagem (e-book) depositados no Laboratório Virtual, metodologias ativas colaborativas e uso dos recursos tecnológicos - TIC, mais ambiente colaborativo pode possibilitar aos estudantes aprenderem melhor, seja pela característica humanista da proposta em que há uma colaboração para a aprendizagem, fazendo com que eles vejam o outro e se coloquem no lugar dele (Roger, 1973), ou pela percepção de aprender significativamente o conteúdo e, por outro lado, reestrutura o fazer pedagógico do professor em uma contínua e permante formação.

\section{REFERÊNCIAS}

BALBINO, J. Objetos de Aprendizagem: contribuições para a genealogia. Recuperado de htt://www. dicas1.com.br/educação_tecnologia/. 2007.

BÉLAIR, L. A formação para a complexidade do ofício do professor. In: Perrenoud, P. et al. (Org.) Formando professores profissionais. Quais as estratégias? Quais competências. 2.ed. Revisada. Porto Alegre: Artmed Editora, 2001.

BETTIO, R.W. de; MARTINS, A. Objetos de Aprendizado - um novo modelo direcionado ao Ensino a Distância. Recuperado de htt://www..abed.org.br/congresso/trabalhos/texto42.htm., 2002.

BORNATTO, G.; SANZOVO, N. (org.). Tecnologias educativas [recurso eletrônico] : cálculo diferencial e integral 1. Série Laboratório Virtual e Modelo Multiplicador por grupo, v. 1. Pato Branco: UTFPR. 2017. 151 p. ISBN: 978-85-99584-08-8 Recuperado de http://pb.utfpr.edu.br/labvirtual/inicio.html, 2017.

CARBONNEAU, M. e HÉTU, J.C. Formação prática dos professores e nascimento de uma inteligência profissional. In: Perrenoud, P. et al. Formando professores profissionais. Quais as estratégias? Quais competências? 2.ed. Revisada. Porto Alegre: Artmed Editora, 2001.

CHARLIER, E. Formar professores profissionais para a formação contínua articulada à prática. In: Perrenoud, P. et al. Formando professores profissionais. Quais as estratégias? Quais competências? 2.ed. Revisada. Porto Alegre: Artmed Editor, 2001.

FERNÁNDEZ, A.G. De la epistemolologia a la sociología. La cara oculta de la pedagogía tecnológica. Contextos X/19-20, 1992 (pp. 321-339).

FRAGELLI, R. Trezentos: aprendizagem ativa e colaborativa como uma alternativa ao problema da ansiedade em provas. Revista Eletrônica Gestão \& Saúde. Vol. 6 (Supl. 2). Abril, 2015 p.860-72.

GATTI, B. Formação do professor pesquisador para o ensino superior: desafios. In: IV Congresso Paulista de Formação de Professores. Águas de Lindóia, SP, 2003.

GATTI, B.; BARRETTO, E.S.S. Professores: aspectos de Sua profissionalização, formação e valorização social. Relatório de Pesquisa. Brasília: Unesco, 2009.

GATTI, B; NUNES, M. M. R. (Org.). (2009). Formação de professores para o ensino fundamental: estudo de currículos das Licenciaturas em pedagogia, língua português, matemática e Ciências Biológicas. São Paulo: FCC.(Textos FCC,n. 29).

GARCÍA-VALCÁRCEL, A. Tecnología educativa - Implicaciones educativas del desarrollo tecnológico. 
In: CASANOVA, M. Antonia (Dirección)I . Colección Aula Abierta. Editorial La Muralla, S.A, Imprime Ibérica Grafic, S.A. (Madrid), 2003.

GIL, A. C. (1999). Métodos e técnicas de pesquisa social. São Paulo: Atlas, 1999.

IMBERNÓN, F. Formação Continuada de professores. Porto Alegre: Artmed, 2010.

KOEHLER, M. MISHRA, P. Introducting Technological. In: AACTE (Eds.). The handbook of technological pedagogical content knowledge for educators. New York. NY. MacMillan, 2008.

MACHADO, E; SANZOVO, N. (org.). Tecnologias educativas [recurso eletrônico]: geometria analítica e álgebra linear. Série Laboratório Virtual e Modelo Multiplicador por grupo, v. 2. Pato Branco: UTFPR. 2017. 337 p. ISBN: 978-85-99584-09-5 Recuperado de http://pb.utfpr.edu.br/labvirtual/inicio. html. 2017.

MADRIGAL, Psic. Pastor HERNÁNDEZ . (2016). Funciones de la tutoria virtual. Recuperado de http://craig.com.ar/biblioteca/8/FuncionesDeLaTutoriaVirtual-Hernandez.pdf. 2016.

NÓVOA, A. Professores: O futuro ainda demora muito tempo? In: Nóvoa, A. (2009). Professores Imagens do futuro presente. EDUCA. Instituto de Educação Universidade de Lisboa. Lisboa. Portugal, $2009^{\mathrm{a}}$.

NÓVOA, A. Para uma formação de professores construída dentro da profissão. In: In: Nóvoa, A. Professores Imagens do futuro presente. EDUCA. Instituto de Educação Universidade de Lisboa. Lisboa. Portugal, 2009b

PERALTA, H.; COSTA, F. A. Teacher's Competence and Confidence regarding the use of ICT. S í s i fo/educationalsciencesjournal no. $3 \cdot \mathrm{may} / \mathrm{aug} 07$.

PERRENOUD. P. O trabalho sobre o habitus na formação de professores: análise das peráticas e tomada de consciência. In: Perrenoud, P. et al. Formando professores profissionais. Quais as estratégias? Quais competências? 2.ed. Revisada. Porto Alegre: Artmed Editora, 2001.

PERRENOUD, P. Ensinar: agir na urgência, decidir na incerteza. Porto Alegre: Artmed, 2000.

QUARTIERO, E. M.; FANTIN, M.; BONILLA, M.H. Políticas para la inclusión de las TIC em las escuelas públicas brasileñas: contexto y programas. Revista Científica Iberoamericana de Tecnologia Educativa - Campus Virtuales, n.01, v1 p. 115-126, 2012.

ROGERS, C.R. Liberdade para aprender. 2. ed. Belo Horizonte (MG): Interlivros, 1973.

SACRISTÁN, J. G. Poderes instáveis em Educação. Tradução de Beatriz Afonso Neves. Porto Alegre: Artes Médicas, 1999.

SANZOVO, N.; SILVA, C.A. Mesa heptagonal separável com estação central multitarefa. (Em fase de patenteamento). Pato Branco: UTFPR, 2017.

SCHÖN, D. Os professores e sua formação. Coord. D

e Nóvoa; Lisboa, Portugal, Dom Quixote, 1997.

SOSSAI, F. C.; LUNARDI-MENDES, G. M.; PACHECO, J.A. Currículo e novas tecnologias em tempos de globalização. Perspectiva. V.27, 2009, p.19-46. 


\section{CAPÍTULO 16}

\section{A UNIVERSIDADE, A EDUCAÇÃO DE ADULTOS E A INCLUSÃO SOCIAL}

Armando Paulo Ferreira Loureiro

Universidade de Trás os Montes e Alto Douro - UTAD

Antonio Izomar Rodrigues Madeiro João Carlos Pereira Coqueiro Maria José Quaresma Portela Corrêa Manoel Domingos Castro Oliveira Sílvia De Fátima Nunes Da Silva

RESUMO: Esse estudo tem como meta discorrer sobre o papel da Universidade, a Educação de Adultos e a Inclusão Social. O MEC/CAPES está investindo com políticas públicas voltadas para esse nível de ensino, as pessoas que não puderam estudar podem retornar à escola com as opções: graduação e formação contínua. Nesse contexto a EaD através da Universidade Aberta do Brasil tornou-se uma das alternativas educacionais capazes de ajudar as pessoas que necessitam de qualificação a nível superior. É importante que a sociedade tenha consciência do papel que a EaD tem na Educação de Adultos.

PALAVRAS-CHAVE: Universidade; Inclusão Social; Educação de Adultos.

ABSTRACT: This study aims to discuss the role of the University, Adult Education and Social Inclusion. The MEC / CAPES is investing with public policies aimed at this level of education, people who were not able to study can return to school with the options: graduation and continuing education. In this context, EAD through the Open University of Brazil has become one of the educational alternatives capable of helping people who need qualification at a higher level. It is important that society is aware of the role that ED has in Adult Education. KEYWORDS: University; Social inclusion; Adult Education.

\section{INTRODUÇÃO}

A análise das políticas públicas educacionais voltadas para a Educação de Adultos é relevante no Brasil, nos ajuda a perceber que essa modalidade de ensino permite às pessoas que não tiveram meios ou puderam concluir seus estudos a merecida oportunidade de estudar. No Brasil ocorreu um processo de reformas educacionais que resultou na construção dos compromissos éticos, políticos e sociais firmados pela Constituição Federal de 1988.

Num contexto, em que se ressalta a importância da Educação de Adultos não se pode esquecer a relação entre a sociedade e a universidade deve ser a melhor possível, para que a universidade possa provocar a comunidade a se envolver e participar da mesma e com isso motivar a mesma a estimular 
o desenvolvimento local e comunitário na região onde a instituição está localizada.

\section{PAPEL DAS UNIVERSIDADES NO DESENVOLVIMENTO SOCIAL E COMUNITÁRIO}

A Universidade é uma das instituições mais importantes da atualidade, tem uma grande responsabilidade perante a sociedade e é uma daquelas a quem mais se têm exigido resultados positivos na comunidade onde a mesma se insere. Exige-se maior participação da Universidade na resolução dos problemas na sociedade.

Para Loureiro, (1999): "A problemática da relação entre Universidade e Sociedade tem vindo a ser discutida há muito tempo. Desde a formação daquela, na Idade Média, que se pede resposta para determinadas exigências às quais foi respondendo: as reflexões teológicas ocorridas no seu interior reflectiam, de algum modo, às preocupações intelectuais daqueles séculos.

De acordo com os estudos de Loureiro, (1999) a Universidade é uma organização complexa, que tem características próprias que a distingue das demais organizações e isto ocorre porque existe uma forte política na base das tomadas de decisões, com uma estrutura fragmentada e descentralizada, o que faz com que o poder esteja demasiadamente espalhado e isso provoca uma dificuldade em medir a produção na ação organizacional e não existem padrões de desempenho e compromisso com resultados.

Para Nogueira, (2008): "A universidade existe para produzir conhecimento, gerar pensamento crítico, organizar e articular os saberes, formar cidadãos, profissionais e lideranças intelectuais". O desempenho dessas nobres e decisivas funções, porém, não é algo que se resolva no plano abstrato, mas com atividades práticas.

\section{A FUNÇÃO DA UNIVERSIDADE}

A universidade desempenha importantes papéis para o desenvolvimento humano, regional e sustentável na sociedade contemporânea. Ela tem a missão não apenas de possibilitar aos alunos a obtenção de um diploma, ofertar um curso de extensão ou formação técnica ou profissional para que a pessoa consiga um emprego e remuneração satisfatória, mas deve ser capaz de produzir novos conhecimentos e aplicá-los à realidade social, considerando a necessidade de ser acessível a toda a sociedade, em todos os níveis sociais para que haja inclusão social, exercendo tanto uma função social quanto política de desenvolvimento sustentável. (Luckesi, 1998).

A universidade tem o dever de retribuir o investimento que recebe da comunidade, desenvolvendo estudos, pesquisas e projetos de extensão compatíveis com as reais necessidades da população em benefício comum, isto é, ela deve contribuir para solucionar os atuais problemas da sociedade. Outra função da universidade é auxiliar os alunos para que eles tenham uma opinião crítica diante da realidade social para que haja um avanço científico, tecnológico e cultural, isto é, a universidade tem como 
função o dever de estar comprometida com a construção de uma sociedade mais justa e igualitária.

Tem a função de absorver demandas e expectativas sociais variadas, às quais precisa corresponder, e ao mesmo tempo agir para propor pautas e agendas, contribuir para a construção da autoconsciência social, alargar fronteiras culturais e submeter à crítica a realidade, as estruturas sociais e as relações de dominação. Por isso funciona melhor quanto mais republicana e democrática for, o Estado com o qual se relaciona.

As universidades e equivalentes instituições de ensino superior formam as futuras gerações de cidadãos e possuem conhecimentos de especialidade em todos os campos da investigação, tanto em tecnologia como nas ciências naturais, humanas e sociais.

Para Silva, (2011) "A extensão universitária é uma forma de interação que deve existir entre a universidade e a comunidade na qual ela está inserida, uma espécie de ponte permanente entre a universidade e os diversos setores da sociedade. Funciona como uma via de duas mãos em que a universidade leva conhecimentos e/ou assistência à comunidade e recebe dela influxos positivos em forma de retroalimentação, tais como suas reais necessidades, anseios e aspirações.

Além disso, a universidade aprende com o saber dessas comunidades". A autora demonstra em suas palavras que a extensão universitária é uma forma de interação entre a universidade e a sociedade e que a mesma deve produzir e adquirir conhecimentos, propor soluções para o desenvolvimento social e comunitário.

Um país só é desenvolvido socialmente quando seus habitantes têm qualidade de vida, para que se saiba se essa população tem um ótimo nível de vida é necessário comparar entre as populações de outros países para se avaliar o nível de desenvolvimento social de um país.

Nos anos 50 a ONU (Organização das Nações Unidas) passou a divulgar o desenvolvimento comunitário como: "processo através do qual cada povo participa do planejamento e da realização de programas que se destinam a elevar o padrão de suas vidas. Isso implica na colaboração indispensável entre os governos e o povo para tornar eficazes os esquemas de desenvolvimento viáveis e equilibrados" (Ammann, 1981).

No Brasil, os primeiros projetos de desenvolvimento comunitário se desenvolveram na década de 1940 com a realização de convênios na produção de alimentos, educação rural e industrial.

O papel das universidades neste desenvolvimento social e comunitário é relevante, pois são elas que promovem ações voltadas para que ocorra esse desenvolvimento tão desejado por toda a população brasileira. 


\section{A EDUCAÇÃO DE ADULTOS NO BRASIL}

A história da Educação de Adultos no Brasil primeiro esteve ligada à formação profissional, é nesse contexto que entra a EaD, capacitando pessoas adultas para exercer certas atividades ou dominar determinadas habilidades, sempre motivadas por questões de mercado, depois foi que se passou a vê-la como uma alternativa educacional que poderia resolver muitos problemas no país, tais como a extensão territorial, a falta de estradas, a falta de universidades, de equipamentos e de professores qualificados.

Para Moran, a educação a distância é uma alternativa viável de educação e isso ocorre desde o a última década do século XX no Brasil, após a promulgação da LDB Lei $n^{\circ}$ 9.394/1996. "Estamos caminhando para uma aproximação sem precedentes entre os cursos presenciais (cada vez mais semipresenciais) e os a distância. Os presenciais terão disciplinas parcialmente a distância e outras totalmente a distância. [...] Teremos inúmeras possibilidades de aprendizagem que combinarão o melhor do presencial (quando possível) com as facilidades do virtual. Em poucos anos dificilmente teremos um curso totalmente presencial. (Moran, 2005)."

A história da EaD no Brasil tem seu marco inicial com a fundação da Rádio Sociedade do Rio de Janeiro em 1923, por Roquete Pinto, que em sua programação transmitia programas de literatura, de línguas, literatura infantil e sobre assuntos de interesse comunitários, ou seja, iniciou-se por rádio difusão.

O início dos anos 1960, a Diocese de Natal (Rio Grande do Norte) criou as escolas radiofônicas, que deram origem ao Movimento de Educação de Base (MEB), cuja "preocupação básica era alfabetizar e apoiar os primeiros passos da educação de milhares de jovens e adultos, principalmente da região Norte e Nordeste do Brasil".

Nos anos 70, o destaque foi o Projeto Minerva, integrado ao Ministério da Educação, Fundação Padre Anchieta e Fundação Padre Landell de Moura (FEPAM), fundamentados na Lei $n^{\circ}$ 5.692/69 que enfatizava a educação de adultos. O Projeto Minerva transmitia em rede nacional, através de rádio e televisão, seu objetivo era preparar alunos para os exames supletivos de Capacitação Ginasial e Madureza Ginasial. Em 1978 foi criado o Telecurso $2^{\circ}$ grau, através de uma parceria da Fundação Padre Anchieta e Fundação Roberto Marinho.

Em 1979 houve a criação da Fundação Centro Brasileiro de Televisão Educativa (FCTVE), utilizando programas de televisão no projeto Movimento Brasileiro de Alfabetizacão (MOBRAL). Neste mesmo ano, a Coordenacão de Aperfeicoamento do Pessoal de Ensino Superior (CAPES) faz experimentos de formacão de professores do interior do país através da implementação da Pós-Graduacão Experimental a Distância. Já em 1984, em São Paulo, é criado o Projeto Ipe, cujo objetivo era o de aperfeicoar professores para o Magistério de $1^{\circ}$ e $2^{\circ}$ graus.

No contexto da legislação em EaD, é notório que as bases legais para essa modalidade de educação surgiram tardiamente comparado com o seu aparecimento. 
A partir de 20 de dezembro de 1996, com a promulgação da Lei de Diretrizes e Bases da Educação Nacional (LDBEN), Lei n 9.394/96, a Educação a Distância passa a ser regulamentado pelo Decreto $n^{\circ} 5.622$, publicado no Diário Oficial da União em 20 de dezembro de 2005. A Resolução $n^{\circ} 1$ de 03 de abril de 2001, do Conselho Nacional de Educação (CNE) estabeleceu as normas para o funcionamento de cursos da pósgraduação.

Com todas essas regulamentações foram adotados alguns critérios para esse nível de ensino, tais como: para a educação básica, de acordo com o Art. $2^{\circ}$ do Decreto $n^{\circ} 2.498 / 98$, os cursos à distância com certificação ou diploma de conclusão do ensino fundamental para jovens e adultos, de ensino médio, da educação profissional e de graduação são ofertadas por intermédio de instituições públicas ou privadas especificamente credenciadas para esse fim.

Quanto à oferta de cursos à distância, o Decreto $n^{\circ} 2.561 / 98$ vem delegar competências às autoridades integrantes dos sistemas de ensino, na qual trata o Art. $8^{\circ}$ da LDB, em que promove os atos de credenciamento de instituições localizadas no âmbito de suas respectivas atribuições.

Percebemos a importância de maiores investimentos na educação de adultos, já que é através desses investimentos que podemos melhorar os índices de analfabetismo e qualificação das pessoas tanto a nível médio quanto em nível superior.

\section{EDUCAÇÃO DE ADULTOS COMO INSTRUMENTO DE INCLUSÃO}

A Educação de Jovens e Adultos (EJA), a partir da Lei de Diretrizes e Bases da Educação Nacional (LDBEN), lei n 9.394 de1996 (BRASIL, 1996) passou a ser uma modalidade da educação básica nas etapas do ensino fundamental e médio. Já está legalizada, e quando há vontade de mudar o quadro de analfabetismo existente no país, com medidas certas e de incentivo para melhorar a educação dessas pessoas que não tiveram oportunidade de estudar na idade certa essas políticas públicas terão um caráter de inclusão social e pessoal.

Na LDBEN (Lei de Diretrizes e Bases da Educação Nacional) Lei 9.394/96, em seu artigo 37 e inciso primeiro consta que: "A educação de jovens e adultos será destinada àqueles que não tiveram acesso ou continuidade de estudos no ensino fundamental e médio na idade própria. $\S 1^{\circ}$ - Os sistemas de ensino assegurarão gratuitamente aos jovens e aos adultos, que não puderam efetuar os estudos na idade regular, oportunidades educacionais apropriadas, consideradas as características do alunado, seus interesses, condições de vida e de trabalho, mediante cursos e exames (Brasil, 1996).

De acordo com o artigo citado acima percebemos que as leis já favorecem essas pessoas, porém percebemos que faltam ações dinâmicas e eficazes para que se obtenha uma educação que tenha como objetivo servir de instrumento de inclusão. De acordo com as Diretrizes Curriculares Nacionais para a Educação de Jovens e 
Adultos, a EJA: "[...] considerará as situações, os perfis dos estudantes, as faixas etárias e se pautará pelos princípios de eqüidade, diferença e proporcionalidade na apropriação e contextualização das diretrizes curriculares nacionais e na proposição de um modelo pedagógico próprio, de modo a assegurar: I - quanto à equidade, a distribuição específica dos componentes curriculares a fim de propiciar um patamar igualitário de formação e restabelecer a igualdade de direitos e de oportunidades face ao direito à educação... (Brasil)"

Se considerarmos o perfil dos alunos da EJA observaremos que se pode realizar um trabalho de qualidade baseado em suas próprias histórias de vidas, tornando seus conhecimentos empíricos em conhecimentos científicos, sistematizados e capazes de serem úteis em suas vidas.

Segundo Freire (1987) o direito à educação não se reduz somente a estar na escola, mas sim em aprender. E, aprender para tomar consciência de seu estado de opressão, para que assim possa se libertar daqueles que o oprimem Em geral, os estudantes da EJA possuem uma considerável experiência de vida que deve ser respeitada e preservada. E, já aprenderam diferentes coisas em diferentes contextos pela necessidade que a vida lhes impõe.

\section{APRESENTAÇÃO E ANÁLISE DOS DADOS}

Essa pesquisa ocorreu no município de Nina Rodrigues - Maranhão, localizada na região Nordeste do Brasil. É um município pequeno, com cerca de quinze mil habitantes e em 2009 foi inaugurada a Universidade Aberta do Brasil. Desde a criação do Polo Tecnológico UAB II de Nina Rodrigues, a instituição funcionou com os cursos de Administração Pública, Filosofia, Pedagogia, Matemática, especializações latu sensus e alguns cursos de formação contínua voltados para adultos. que necessitavam urgentemente se qualificar de acordo com as exigências legais

Em 2017, foram implantados novos cursos de Administração, Pedagogia, Geografia, Matemática, Letras/Português e Ciências da Computação, com um total de 310 alunos matriculados e estudando os respctivos cursos de graduação.

O método utilizado neste trabalho foi uma revisão bibliográfica e um estudo de caso, com quatro participantes, dentre eles, dois formandos adultos e da EaD e oriundos da UAB local e dois empresários locais do ramo de hotelaria e alimentação, os quais discorrem sobre o antes e o depois da implatação da UAB..

Neste estudo de caso as perguntas foram voltadas para o antes e o depois da criação da UAB no município. E vamos caracterizar os formandos em F1 e F2 e os empresários de EH empresário de hotelaria e EA empresário de alimentação e serão expostas através de tabelas.

A primeira pergunta para os formandos foi a seguinte:

$\left.1^{\mathrm{a}}\right)$ Comente sobre sua vida e profissão antes de se formar através da modalidade EaD na UAB de Nina Rodrigues. 


\begin{tabular}{|c|c|}
\hline Formando 1 & Formando 2 \\
\hline $\begin{array}{l}\text { Era efetivo, porém ganhava menos que } \\
\text { meus colegas graduados, sem contar que } \\
\text { a LDB Lei n } 9.394 / 96 \text { exigia que todos os } \\
\text { docentes se graduassem, eu já havia perdido } \\
\text { as esperanças de ter o curso superior, meu } \\
\text { minguado salário não permitia que eu fosse } \\
\text { estudar numa instituição privada. Em } 2009 \\
\text { quando inauguraram a UAB aqui em Nina } \\
\text { Rodrigues e eu fui aprovado no vestibular e de } \\
\text { uma universidade pública eu nem acreditava, } \\
\text { era a realização dos meus sonhos. }\end{array}$ & $\begin{array}{l}\text { Não era concursada, as vezes trabalhava } \\
\text { como contratada e por apenas } 10 \text { meses } \\
\text { ganhando apenas o salário mínimo vigente. } \\
\text { Dependia da vontade política e não conseguia } \\
\text { planejar estudar em uma universidade } \\
\text { pública o que ganhava no contrato era } \\
\text { muito pouco e ainda tinha de economizar } \\
\text { para quando estivesse sem trabalho o que } \\
\text { ocorria constantemente. Ao ser aprovada } \\
\text { no vestibular da UAB foi a maior alegria que } \\
\text { senti, perdendo apenas para o momento da } \\
\text { formatura e eu tocar no meu diploma. }\end{array}$ \\
\hline
\end{tabular}

Tabela 1.

Antes da UAB

Como vimos, o antes da UAB ser implantada no município era cheio de dúvidas para os profissionais da educação, o F1 era efetivo, porém ganhava pouco e a LDB exigia que ele se graduasse. Enquanto o F2 só trabalhava temporariamente, era difícil para eles sonharem com um curso de nível superior.

A segunda pergunta da entrevista foi a seguinte:

$2^{a}$ ) Após ter realizado sua formartura no Polo Tecnológico UAB II de Nina Rodrigues, relate sobre os benefícios e conquistas que você adquiriu?

\begin{tabular}{|c|c|}
\hline Formando 1 & Formando 2 \\
\hline $\begin{array}{l}\text { Entrei imediatamente com o pedido de } \\
\text { promoção, no mês seguinte já senti a } \\
\text { diferença no meu salário, aumentou quase o } \\
\text { dobro. Estudei duas pós-graduações e estou } \\
\text { pensando em estudar um mestrado. } \\
\text { Os benefícios que adquiri após minha } \\
\text { formatura foram inúmeros, posso citar alguns: } \\
\text { fui promovido; passei em outro concurso; } \\
\text { atualmente ganho o triplo de antes; passei a } \\
\text { exercer cargos e funções mais específicas, ou } \\
\text { seja, foi uma bênção ter estudado em nossa } \\
\text { UAB. }\end{array}$ & $\begin{array}{c}\text { Fiz o concurso público em dois municípios e } \\
\text { fui aprovada, hoje me sinto segura, adquiri } \\
\text { a tão sonhada estabilidade, tenho veículo } \\
\text { próprio, continuei meus estudos. Pude } \\
\text { sonhar em ter filhos, algo impossível antes na } \\
\text { situação incerta que vivi. } \\
\text { Foram tantos benefícios que recebi da UAB } \\
\text { que nem posso enumerá-los. Agora novos } \\
\text { cursos estão funcionando, e outras pessoas } \\
\text { também serão beneficiadas. }\end{array}$ \\
\hline
\end{tabular}

Tabela 2.

Benefícios e conquistas após a formatura

Nesta última pergunta sobre depois da formatura percebe-se que houve sim desenvolvimento social, intelectual e profissional, os benefícios que esses alunos obtiveram foram muitos, isto é, a Educação a Distância é realmente uma alternativa viável para solucionar muitos problemas e capaz de promover a inclusão social.

A próxima pergunta da entrevista está voltada para um empresário de hotelaria e um empresário de alimentação, e a pergunta voltada a eles será:

$1^{\text {a) }}$ Quais os benefícios que os empresários de nosso município obtiveram após 


\begin{tabular}{|c|c|}
\hline Empresário hoteleiro & Empresário alimentação \\
\hline Antes da implantação da universidade em & Antes haviam somente os restaurantes \\
nosso município só tínhamos um hotel, & localizados às margens do rio. Atualmente \\
atualmente temos 5, nos finais de semana & temos o dobro, nos finais de semana é \\
todos os nossos quartos são ocupados por & preciso reservar com antecedência, temos \\
professores e familiares desses professores, & vários funcionários, isto é, a implantação da \\
alunos de outros municípios também & universidade trouxe mais oportunidades para \\
se hospedam conosco, aumentaram os & todos, são as lanchonetes, os restaurantes, \\
empregos e demonstrou que a universidade & os empregos de garçons, cozinheiras, caixa, \\
trás desenvolvimento social e comunitário nos & considero que a universidade provocou muito \\
locais onde está inserida. & desenvolvimento no município. \\
\hline
\end{tabular}

Tabela 3.

Benefícios obtidos após UAB

Os dois entrevistados revelaram o antes e o depois da implantação da universidade. A vinda de professores e estudantes de outros municípios gerou renda, empregos, para muita gente. $\mathrm{O}$ desenvolvimento comunitário ocorre através de um processo de desenvolvimento socioeconômico que deve partir da população local e para que isso ocorra faz-se necessário que a universidade e a comunidade estejam interagindo sempre em busca de alternativas para o desenvolvimento das potencialidades daquela região. E foi o que ocorreu em nosso município, essa interação ajudou muitas famílias a terem seu próprio negócio.

Vimos nessas entrevistas o quanto é importante a educação para a sociedade contemporânea, os alunos melhoraram suas vidas intelectuais, econômicas e sociais, os empresários tiveram oportunidades de se desenvolverem, o município onde a UAB está localizado também se desenvolveu, gerou mais empregos, trabalhadores autônomos puderam sonhar com seu próprio negócio, isto é, fica comprovado que a formação contínua é capaz mudar uma realidade.

\section{CONCLUSÃO}

Nessa perspectiva, constatamos que o polo da UAB implantada no município de Nina Rodrigues, através da Educação a Distância (EaD) é capaz sim de mudar para melhor a vida de um município, qualificando seus professores e outros profissionais, provocando o tão sonhado desenvolvimento humano, econômico, intelectual e social não somente de uma classe, mas de toda a população onde a universidade está atuando.

AEA tanto no Brasil como no mundo deve ser encarada como prioridade, tendo na EaD uma alternativa educacional viável, que deve ser encarada como com respeito e seriedade pelo poder público e pela sociedade civil organizada. Contatou-se também que é somente através da educação que o povo é capaz de transformar positivamente seu mundo e dos que estão próximos. Sabemos que "a educação sozinha não trás 
desenvolvimento, mas sem ela não há desenvolvimento", como dizia o nosso educador

Paulo Freire (1999).

Comprovamos que a Universidade tem uma importante tarefa, a de transmitir conhecimentos científicos, incentivar a pesquisa, realizar intervenções benéficas na comunidade onde está inserida, neste sentido.

\section{REFERÊNCIAS}

Ammann, Safira Bezerra. Ideologia do Desenvolvimento Comunitário no Brasil. São Paulo, Cortez, 1981.

Brasil, Lei $n^{\circ}$ 9.394, de 20 de Dezembro de 1996. Estabelece as diretrizes e bases da educação nacional. Disponível em: http://www.planal to.gov.br/ccivil_03/Leis/L9394.htm Acesso em 17/07/2016.

Brasil, Resolução CNE/CEB n ${ }^{\circ}$ 1, de 5 de julho de 2000. Estabelece as Diretrizes Curriculares Nacionais para a Educação e Jovens e Adultos. Disponível em http://www.educacao.rj.gov.br/index5. aspx?tipo=categ\&iditem=378\&amp;categoria=404\&amp;idsecao=173\&spid=7 Acesso em 17/07/2016.

(Declaração de Hamburgo sobre Educação de Adultos, V Confintea, UNESCO, 1997:42).

Freire, Paulo. Pedagogia do Oprimido. $17^{\text {a }}$ Ed. Paz e Terra, 1987.

Educação como prática da liberdade. 23 ed., Rio de Janeiro: Paz e Terra, 1999.

Junior, Hélio Santiago Ramos. A função da universidade na sociedade do conhecimento.

Disponível em http://egovbrasil.blogspot.com.br/2009/03/funcao-da-universidade-na-sociedade-do. html. Acesso em 18 de Janeiro de 2015.

Loureiro, Armando. Novos Territórios e agentes educativos em sociologia da educação: o caso da educação de adultos. Rev.. Lusófona de Educação n 20, Lisboa, 2011.

Luckesi, Cipriano et al. Fazer universidade: uma proposta metodológica. 10. ed. São Paulo: Cortez, 1998.

Moran. J. M.. Tendências da Educação online no Brasil. 2005. Disponível em http://www.eca.usp.br/ prof/moran/tendencias.htm. Acesso em 10 de outubro de 2016.

Nogueira, Marco Aurélio. Qual o papel da Universidade? Lunes. 18 de fevereiro de 2008. Disponível no site: http://marxbrito.blogspot.com.br/2008/02/qual-o-papel-da-universidade.html Acesso em 10 de janeiro de 2015.

Oliveira, Claudia Hochheim. Qual é o Papel da Extensão Universitária? Algumas Reflexões Acerca da Relação entre Universidade Políticas Públicas e Sociedade. Anais do $2^{\circ}$ Congresso Brasileiro de Extensão Universitária Belo Horizonte - 12 a 15 de setembro de 2004. 


\section{CAPÍTULO 17}

\section{A UTILIZAÇÃO DA COMUNICAÇÃO DIGITAL PELOS PROFESSORES DO CURSO DE RELAÇÕES PÚBLICAS}

Maristela Romagnole de Araujo Jurkevicz Universidade Estadual de Londrina, Departamento de Comunicação

Londrina - Paraná

Joaquim José Jacinto Escola Universidade de Trás-os-Montes e Alto Doro, Departamento de Educação

Regiane Ribeiro Universidade Federal do Paraná, Departamento de Comunicação

RESUMO: Apresentamos alguns dos dados obtidos nos questionários aplicados junto aos professores que ministram aulas no curso de Relações Públicas e alunos das últimas séries, da Universidade Estadual de Londrina, situada no norte do Paraná, no Brasil. O objetivo desta etapa apresentada neste artigo foi o de identificar os aspectos do cenário digital no curso selecionado para investigação e a concepção sobre as Relações Públicas neste novo ambiente, sob o ponto de vista destes dois sujeitos (professores e alunos). Trata-se de uma parcela da investigação realizada na tese de doutoramento em Ciências da Educação desenvolvida na Universidade de Trás-osMontes e Alto Doro (UTAD) - PT.

PALAVRAS-CHAVE: ensino superior de relações públicas, sociedade da informação e do conhecimento, tecnologias da informação e conhecimento, formação profissional.

ABSTRACT: We present some of the data obtained in the questionnaires applied along to teachers who teach classes in the course of Public Relations and alumni of the last series, the Universidade Estadual de Londrina, situated in the North of Paraná, in Brazil. The objective of this step presented in this article was to identify the aspects of the digital scenario in the course selected for research and the conception about Public Relations in this new environment, from the point of view of these two subjects (teachers and students). This is a portion of the research conducted in the doctoral thesis in education developed at the University of Trás-os-Montes e Alto Doro (UTAD) - PT.

KEYWORDS: higher education public relations, information and knowledge society, information and knowledge, vocational training.

\section{I INTRODUÇÃO}

O objetivo de nossa tese apresentada junto à Universidade de Trás-os-Montes e Alto Douro em Portugal, como parte do doutoramento em Ciências da Educação foi pesquisar, avaliar e propor alternativa de arquitetura curricular para o Projeto Pedagógico de Curso, da habilitação 
em Relações Públicas da Universidade Estadual de Londrina, contemplando o uso das Tecnologias da Informação e Comunicação (TIC), a partir de literatura específica e das Diretrizes Curriculares Nacionais. Nossa pretensão foi refletir sobre os desafios impostos pela Sociedade da Informação e do Conhecimento ao ensino superior e mais especificamente à graduação de Relações Públicas. Além do novo contexto digital, o curso de Relações Públicas da Universidade Estadual de Londrina, foco deste estudo, tinha a necessidade de atender as Diretrizes Curriculares Nacionais de 2013. Portanto, um momento oportuno para revisar sua matriz curricular e propor novas metodologias de ensino, como a que foi sugerida ao final do estudo, com a introdução da utilização de metodologias ativas preferencialmente com o uso das TIC no ensino.

No presente artigo apresentamos alguns dos resultados da análise dos dados quantitativos, recolhidos por meio das seguintes fontes de pesquisa, os professores que ministram aulas no Curso de Relações Públicas da Universidade Estadual de Londrina e alunos das terceiras e quartas séries do curso. Para o alcance do objetivo proposto reunimos os dados obtidos por meio dos questionários disponibilizados on-line para os professores e no blog criado especialmente para os alunos. Para a análise das informações utilizamos uma abordagem qualitativa, procurando proceder à interpretação e discussão dos aspectos mais relevantes. De acordo com Gil (2002, p.84):

[...] consiste na organização das ideias com vista em atender aos objetivos ou testar as hipóteses formuladas no início da pesquisa. Assim, cabe nesta etapa estruturar logicamente o trabalho para que ele possa ser entendido como unidade dotada de sentido.

Ainda nesta etapa destaca Amado \& Vieira (2013, p. 378) são combinadas a "informação prévia, explicitação e domínio de conceitos, trabalho sistemático, rigor metodológico e criatividade", transformando os dados recolhidos em dados com significado, despontando a figura do investigador. E nas palavras de Denzin \& Lincoln (2003), o pesquisador qualitativo será um "confeccionador de colchas" (p.5), procurando, costurar, editar e reunir recortes da realidade, ou seja, reagrupar um conjunto de representações que demonstrem as especificidades de uma situação complexa.

\subsection{OBJETIVOS}

Em nosso estudo de caso apresentado na tese, a nosso unidade de análise foi o curso de Relações Públicas da Universidade Estadual de Londrina, com seu projeto pedagógico, grupo de professores e alunos, no período de 2013 a 2016.

Neste recorte apresentamos os resultados obtidos nos questionários disponibilizados on line para os professores do Curso de Relações Públicas da UEL e nos questionários colocados no blog especialmente criado para os alunos das terceiras 
e quarta séries. O objetivo desta etapa foi o de: Identificar os aspectos do cenário digital no curso selecionado para investigação e a concepção sobre as Relações Públicas neste novo ambiente. O objetivo foi desdobrado em dimensões, cada uma delas com mais aspectos que foram analisados e identificados, de acordo com a fonte selecionada para coleta de informações, conforme apresentamos em seguida.

No questionário disponibilizado para os professores investigamos cinco dimensões: 1) Perfil dos Professores, 2) Formação Profissional, 3) Planejamento de Ensino, 4) Utilização das TIC no ensino e, 5) Diretrizes Curriculares Nacionais. Selecionamos para este nosso recorte destacar as seguintes dimensões com alguns de seus aspectos, a dimensão 1, apresentando o perfil dos Professores do curso; a dimensão 5, evidenciando a utilização das TIC no ensino.

Já no questionário direcionado para os alunos, foram analisadas quatro dimensões: 1) Perfil dos alunos, 2) Preparação para o uso das TIC, 3) Planejamento de ensino do professor, 4) Utilização das TIC no ensino pelos professores. Optamos por apresentar os seguintes aspectos: na dimensão 1 o perfil dos alunos das terceiras e quarta séries do curso de Relações Públicas da UEL, na dimensão 4 , identificar a percepção dos alunos quanto a utilização das TIC pelos professores do curso.

\section{I MÉTODO}

Na fase quantitativa de nosso estudo selecionamos a utilização de inquérito por meio de questionários. Para Lobiondo-Wood e Haber (2001) os questionários são instrumentos de registro escritos e planejados para pesquisar dados de sujeitos, por meio de questões relacionadas a conhecimentos, atitudes, crenças e sentimentos. São considerados instrumentos com bom potencial de investigação em educação de acordo com Tuckman (2000), na medida em que possibilitam transformar em dados a informação comunicada diretamente por um sujeito. Na visão de Vilelas (2009) a finalidade do inquérito por questionário consiste em obter, de maneira sistemática e ordenada, a informação, a respeito da população/amostra selecionada para o estudo, referentes às variáveis que são objeto de análise.

Nossa pretensão com a utilização deste instrumento teve os seguintes objetivos indicados por Quivy e Campenhoudt (2003), buscar compreender os modos de vida, comportamentos, valores e opiniões de determinados sujeitos, bem como apreender melhor a análise de um fenômeno social, a partir de informações recebidas dos indivíduos da população selecionada para o estudo e também com a visão de Vilelas (2009), obter informações a respeito de nossa temática junto aos professores e alunos do curso de RP da UEL. 


\subsection{PARTICIPANTES}

Participaram desta fase de nossa investigação 22 professores de um total de 28 que atuavam na área no ano de 2015. Foram selecionados como fonte de coleta de dados os professores que ministraram aulas nos cursos de Relações Públicas no ano de 2015, das seguintes áreas: Relações Públicas (10), Jornalismo (2), Teoria da Comunicação (6) e de outros departamentos da Universidade (10), totalizando 28 professores. Destes, 22 responderam o questionário enviado on line, correspondendo a uma participação de $78,6 \%$ da população.

O perfil dos professores correspondia as questões de número 1 do Questionário aplicado junto a eles nos meses de outubro e novembro de 2015, e continha 8 perguntas. Selecionamos algumas delas para apresentar as características gerais do grupo (sexo, idade, formação na graduação, tempo de serviço, tempo de serviço na docência e regime de trabalho). Participaram da investigação um maior percentual de mulheres $59,1 \%$, seguido de $40,9 \%$ de homens, com a maioria entre 45 e 55 anos (31,8\%) a 56 ou mais $(27,3 \%)$. Constatamos que os respondentes eram em sua maioria $7(32 \%)$ formados em Relações Públicas, seguidos de formados em jornalismo $3(13,5 \%)$ e turismo 2 (9\%). Os demais índices (7) correspondem aos professores de Teoria da Comunicação e de outros departamentos participantes da amostra (Administração, Ciências Contábeis, Ciências Sociais, Filosofia, Letras, Matemática e Psicologia), sendo que três deles não responderam esta questão.

Quanto ao tempo de serviço a maioria (36,4\%) estava entre 21 e 30 anos atuando no mercado e entre 11 e 20 anos $(27,3 \%)$, totalizando $(63,7 \%)$, sendo que a maior parte deles $(22,7 \%)$ assinalou entre 21 e 30 anos deste tempo, prestando serviços na UEL, seguidos de $(13,6 \%)$ entre 11 e 20 anos. Portanto, inferimos que uma grande parte dos professores investigados tinha sua atuação marcada na academia, com pouca experiência no mercado de trabalho formal, fora da docência. E como último dado do perfil a grande maioria $(81,8 \%)$ possuía 40 horas com Tempo Integral de Dedicação Exclusiva (TIDE), utilizando um maior tempo para a área do Ensino de Graduação.

Os alunos selecionados como fontes de informação foram os da $3^{a}$ e $4^{a}$ séries do curso de Relações Públicas dos turnos matutino e noturno. Com uma participação de 58 alunos dos 66 do total desta população, representando $83,3 \%$. As questões referentes ao perfil constavam no questionário on line disponibilizado por meio de um blog construído pela investigadora, com o número 1 , contendo 5 alternativas.

As questões que possibilitaram o delineamento do perfil foram as seguintes: gênero, idade, estado civil, série e identificação da localidade de origem. As características do perfil dos alunos possibilitaram as seguintes leituras, a maioria deles $(79,3 \%)$ pertencia ao sexo feminino, com idade entre 20 e 34 anos $(93,1 \%)$ e a grande maioria de solteiros $(98,3 \%)$. Do total da amostra $\mathrm{N}=58$ participaram 32 alunos $(55,2 \%)$ da $4^{a}$ série e 26 alunos $(44,8 \%)$ da $3^{a}$ série, provenientes em grande parte da cidade 
de Londrina (58,6\%) e $29,3 \%$ do interior de São Paulo.

\begin{tabular}{|c|c|c|}
\hline 1. PERFIL DO ALUNO & fr. & $\%$ \\
\hline \multicolumn{3}{|l|}{ 1.1.GENÊRO } \\
\hline Feminino & 46 & $79.3 \%$ \\
\hline Masculino & 12 & $20.7 \%$ \\
\hline \multicolumn{3}{|l|}{1.2 IDADE } \\
\hline Entre 16 e 19 & 2 & $3.4 \%$ \\
\hline Entre 20 e 34 & 54 & $93.1 \%$ \\
\hline Entre 35 e 44 & 1 & $1.7 \%$ \\
\hline Entre 45 e 55 & 1 & $1.7 \%$ \\
\hline 56 ou + & 0 & $0 \%$ \\
\hline \multicolumn{3}{|l|}{ 1.3 ESTADO CIVIL } \\
\hline Solteiro $(A)$ & 57 & $98.3 \%$ \\
\hline Casado $(\mathrm{A})$ & 1 & $1.7 \%$ \\
\hline Separado $(A)$ & 0 & $0 \%$ \\
\hline Viúvo $(A)$ & 0 & $0 \%$ \\
\hline União Estável & 0 & $0 \%$ \\
\hline \multicolumn{3}{|l|}{ 1.4 SÉRIE QUE ESTÁ CURSANDO } \\
\hline $3^{\mathrm{a}}$ Série & 26 & $44.8 \%$ \\
\hline $4^{a}$ Série & 32 & $55.2 \%$ \\
\hline $\begin{array}{l}\text { 1.5 PROVENIENTE QUE QUAL } \\
\text { LOCALIDADE }\end{array}$ & & \\
\hline Londrina & 34 & $58.6 \%$ \\
\hline Outras cidades do Paraná & 3 & $5.2 \%$ \\
\hline Interior de São Paulo & 17 & $29.3 \%$ \\
\hline \multirow[t]{2}{*}{ Outros } & 4 & $6.9 \%$ \\
\hline & $\mathrm{N}=22$ & \\
\hline
\end{tabular}

Tabela 1. Caracterização dos Alunos constituintes da investigação

\section{I RESULTADOS}

Procuramos examinar na dimensão - Utilização das TIC no ensino de Relações Públicas, em que medida os professores se utilizavam de computadores e Internet em suas atividades de ensino; quais os serviços mais utilizados e o quanto estimulavam os alunos a utilizarem as TIC em sala de aula. E com relação aos alunos, buscamos dimensionar em que medida percebiam a utilização de computadores e Internet pelos professores, em suas atividades de ensino; quais os serviços mais utilizados e o quanto eram estimulados pelos seus professores a utilizarem as TIC em sala de aula. Elaboramos dois gráficos (gráfico 1 e 2) e duas tabelas (tabela 2,3) para a análise destas questões. 


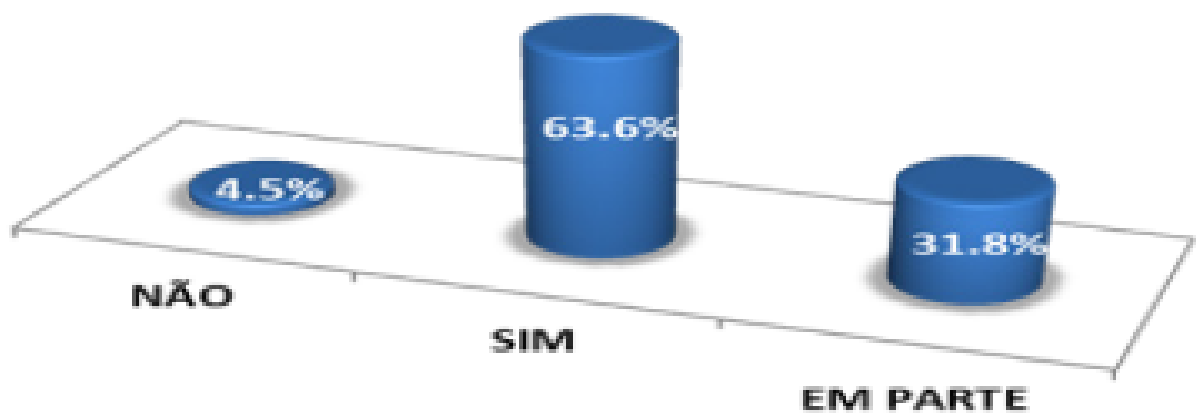

Gráfico 1. Utilização dos serviços da Internet nas disciplinas que ministra em RP - Professores

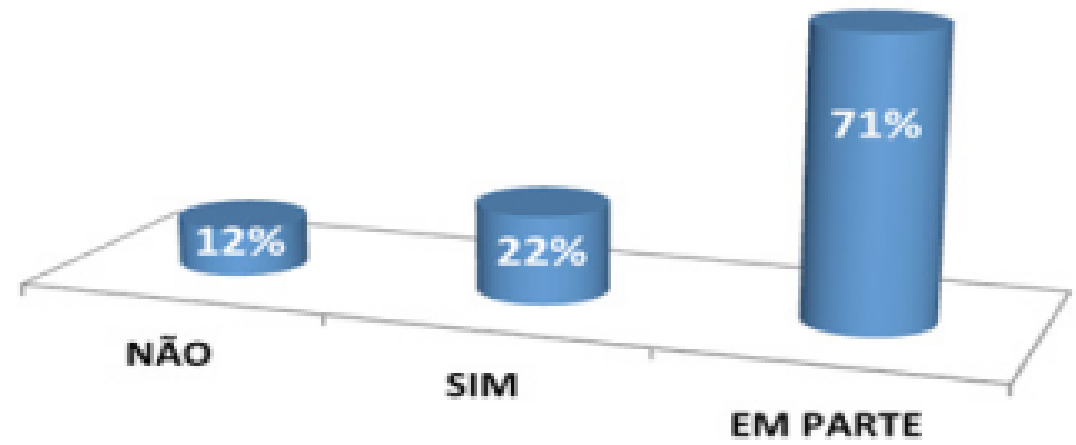

Gráfico 2. Percepção de alunos sobre a utilização dos serviços da Internet nas disciplinas oferecidas pelo curso de RP - Alunos

Os gráficos nos mostraram uma relativa incorporação dos serviços da Internet pelos professores do curso, com $63,6 \%$ afirmando o seu uso e 3,8\% mencionando um uso parcial. No ponto de vista dos alunos pesquisados existia também um entendimento de razoável inserção das TIC no ensino, mas seus apontamentos estavam invertidos em relação aos professores, considerando uma utilização parcial da Internet pelos seus professores com $73 \%$ e $22 \%$ indicando como efetiva. 
Frequência de utilização dos serviços da internet no semestre letivo

\begin{tabular}{|c|c|c|c|}
\hline \multirow{6}{*}{ CORREIO ELETRÔNICO } & Não conheço & 2 & $9.5 \%$ \\
\hline & $1 \mathrm{x}$ a cada semestre & 0 & $0 \%$ \\
\hline & $1 \mathrm{x}$ a cada bimestre & 0 & $0 \%$ \\
\hline & $1 \times$ por mês & 4 & $19 \%$ \\
\hline & 1x a cada 15 dias & 4 & $19 \%$ \\
\hline & Diariamente ou pelo menos $1 \times$ por semana & 11 & $52.4 \%$ \\
\hline \multirow{6}{*}{ FÓRUM } & Não conheço & 8 & $38.1 \%$ \\
\hline & $1 \mathrm{x}$ a cada semestre & 6 & $28.6 \%$ \\
\hline & 1x a cada bimestre & 2 & $9.5 \%$ \\
\hline & $1 \times$ por mês & 2 & $9.5 \%$ \\
\hline & $1 \times$ a cada 15 dias & 0 & $0 \%$ \\
\hline & Diariamente ou pelo menos $1 \times$ por semana & 3 & $14.3 \%$ \\
\hline \multirow{6}{*}{ CHAT } & Não conheço & 9 & $42.9 \%$ \\
\hline & $1 \times$ a cada semestre & 7 & $33.3 \%$ \\
\hline & $1 \times$ a cada bimestre & 2 & $9.5 \%$ \\
\hline & $1 \times$ por mês & 1 & $4.8 \%$ \\
\hline & 1x a cada 15 dias & 1 & $4.8 \%$ \\
\hline & Diariamente ou pelo menos $1 \times$ por semana & 1 & $4.8 \%$ \\
\hline \multirow{6}{*}{ SITES, BLOGS, WIKIS } & Não conheço & 3 & $14.3 \%$ \\
\hline & $1 \times$ a cada semestre & 4 & $19 \%$ \\
\hline & $1 \times$ a cada bimestre & 1 & $4.8 \%$ \\
\hline & $1 \times$ por mês & 0 & $0 \%$ \\
\hline & 1x a cada 15 dias & 6 & $28.6 \%$ \\
\hline & Diariamente ou pelo menos $1 \times$ por semana & 7 & $33.3 \%$ \\
\hline \multirow{6}{*}{ VIDEOCONFERÊNCIA } & Não conheço & 12 & $57.1 \%$ \\
\hline & $1 \times$ a cada semestre & 7 & $33.3 \%$ \\
\hline & 1x a cada bimestre & 1 & $4.8 \%$ \\
\hline & 1x por mês & 0 & $0 \%$ \\
\hline & 1x a cada 15 dias & 0 & $0 \%$ \\
\hline & Diariamente ou pelo menos $1 \times$ por semana & 1 & $4.8 \%$ \\
\hline \multirow{6}{*}{ REDES SOCIAIS } & Não conheço & 6 & $28.6 \%$ \\
\hline & $1 \times$ a cada semestre & 4 & $19 \%$ \\
\hline & 1x a cada bimestre & 0 & $0 \%$ \\
\hline & $1 \times$ por mês & 1 & $4.8 \%$ \\
\hline & $1 \times$ a cada 15 dias & 3 & $14.3 \%$ \\
\hline & Diariamente ou pelo menos $1 \times$ por semana & 7 & $33.3 \%$ \\
\hline OUTROS & & - & - \\
\hline
\end{tabular}

Tabela 2. Frequência de utilização dos serviços da Internet no semestre letivo pelos professores 


\begin{tabular}{|c|c|c|c|}
\hline \multicolumn{2}{|c|}{ UTILIZAÇÃO DAS TIC PELOS PROFESSORES DO CURSO } & \multirow[t]{2}{*}{ fr. } & \multirow[t]{2}{*}{$\%$} \\
\hline Frequência de utilização dos s & s da internet pelos professores no semestre & & \\
\hline \multirow{7}{*}{ CORREIO ELETRÔNICO } & Não conheço & 1 & $1.9 \%$ \\
\hline & Não utilizam & 5 & $9.4 \%$ \\
\hline & $1 \mathrm{x}$ a cada semestre & 2 & $3.8 \%$ \\
\hline & $1 \times$ a cada bimestre & 2 & $3.8 \%$ \\
\hline & 1x por mês & 3 & $5.7 \%$ \\
\hline & $1 \times$ a cada 15 dias & 13 & $24.5 \%$ \\
\hline & Diariamente ou pelo menos $1 \times$ por semana & 27 & $50.9 \%$ \\
\hline \multirow{7}{*}{ FÓRUM } & Não conheço & 6 & $11.3 \%$ \\
\hline & Não utilizam & 41 & $77.4 \%$ \\
\hline & $1 \times$ a cada semestre & 2 & $3.8 \%$ \\
\hline & $1 \times$ a cada bimestre & 2 & $3.8 \%$ \\
\hline & $1 \times$ por mês & 2 & $3.8 \%$ \\
\hline & $1 \mathrm{x}$ a cada 15 dias & 0 & $0 \%$ \\
\hline & Diariamente ou pelo menos $1 \times$ por semana & 0 & $0 \%$ \\
\hline \multirow{7}{*}{ CHAT } & Não conheço & 4 & $7.7 \%$ \\
\hline & Não utilizam & 36 & $69.2 \%$ \\
\hline & $1 \times$ a cada semestre & 4 & $7.7 \%$ \\
\hline & $1 \times$ a cada bimestre & 3 & $5.8 \%$ \\
\hline & $1 \times$ por mês & 2 & $3.8 \%$ \\
\hline & $1 \times$ a cada 15 dias & 0 & $0 \%$ \\
\hline & Diariamente ou pelo menos $1 \times$ por semana & 3 & $5.8 \%$ \\
\hline \multirow{7}{*}{ SITES, BLOGS, WIKIS } & Não conheço & 3 & $5.7 \%$ \\
\hline & Não utilizam & 12 & $22.6 \%$ \\
\hline & $1 \times$ a cada semestre & 12 & $22.6 \%$ \\
\hline & $1 \times$ a cada bimestre & 8 & $15.1 \%$ \\
\hline & 1x por mês & 7 & $13.2 \%$ \\
\hline & $1 \mathrm{x}$ a cada 15 dias & 5 & $9.4 \%$ \\
\hline & Diariamente ou pelo menos $1 \times$ por semana & 6 & $11.3 \%$ \\
\hline \multirow{7}{*}{ VIDEOCONFERENCIA } & Não conheço & 5 & $9.4 \%$ \\
\hline & Não utilizam & 40 & $75.5 \%$ \\
\hline & $1 \mathrm{x}$ a cada semestre & 4 & $7.5 \%$ \\
\hline & $1 \times$ a cada bimestre & 1 & $1.9 \%$ \\
\hline & $1 \times$ por mês & 3 & $5.7 \%$ \\
\hline & $1 \times$ a cada 15 dias & 0 & $0 \%$ \\
\hline & Diariamente ou pelo menos $1 \times$ por semana & 0 & $0 \%$ \\
\hline \multirow{7}{*}{ REDES SOCIAIS } & Não conheço & 1 & $1.9 \%$ \\
\hline & Não utilizam & 11 & $20.8 \%$ \\
\hline & $1 \times$ a cada semestre & 12 & $22.6 \%$ \\
\hline & $1 \mathrm{x}$ a cada bimestre & 6 & $11.3 \%$ \\
\hline & 1x por mês & 7 & $13.2 \%$ \\
\hline & $1 \times$ a cada 15 dias & 9 & $17 \%$ \\
\hline & Diariamente ou pelo menos $1 \times$ por semana & 7 & $13.2 \%$ \\
\hline OUTROS & & _ & - \\
\hline
\end{tabular}

Tabela 3 Frequência de utilização dos serviços da Internet no semestre letivo na percepção dos alunos

Três serviços da Internet foram os mais indicados pelos professores como os mais utilizados no semestre letivo em suas disciplinas, com seus alunos: o correio eletrônico com um percentual de $52,4 \%$ de uso semanal, $19 \%$ quinzenal e $19 \%$ mensal; os sites, blogs e wikis com um percentual de $61,9 \%$ em três intervalos, $1 \mathrm{x}$ por semana (33\%), $1 x$ cada 15 dias (28,6\%) e 1x cada semestre (19\%); e as redes sociais com as indicações 1 x por semana (33,3\%); 1 x a cada dia 15 dias (14,3\%); e $1 \times$ cada semestre (19\%), sendo que $28,6 \%$ deles, afirmaram não conhecerem ou não utilizaram esta modalidade com os seus alunos.

Estes mesmos serviços foram percebidos pelos seus alunos como os mais utilizados, contudo os percentuais variaram um pouco. O correio eletrônico teve um 
total de $75,4 \%$ nos intervalos semanal $(50,9 \%)$ e quinzenal $(24,5 \%)$; os sites, blogs e wikis tiveram uma pontuação dispersa em toda escala totalizando $71,6 \%$, iniciando com o intervalo semestral $(22,6 \%)$, no bimestre $(15,1 \%)$, no mês $(13,2 \%)$, na semana $(11,3 \%)$ e a cada 15 dias $(9,4 \%)$. Ainda $22,6 \%$ confirmaram a não utilização deste serviço pelos seus professores. E as redes sociais também receberam uma pontuação dispersa em toda a escala, com um percentual de $77,3 \%$ nos índices $1 \mathrm{x}$ cada semestre (22,6\%); $1 x$ a cada 15 dias (17\%); 1x por mês (13,2\%); 1 x por semana $(13,2 \%)$ e $1 x$ cada bimestre (11,3\%). Uma parcela dos alunos (20,8\%) admitiu a não utilização deste serviço pelos seus professores.

Entre os serviços menos utilizados pelos professores estão a videoconferência com um percentual de $57,1 \%$ na categoria não conhece/não utiliza contra $33,3 \%$ dos professores que utilizam $1 \times$ a cada semestre. Os chats apareceram com 42,9\% no item não conhece/não utiliza, seguidos de 33,3\% de professores que afirmaram utilizar $1 \mathrm{x}$ a cada semestre. $\mathrm{E}$ o fórum com um maior porcentagem na categoria não conhece/ não utiliza (38,1\%), seguidos do item 1 x a cada semestre $(28,6 \%)$ e 1 x por semana (14,3\%). Os alunos foram mais incisivos, afirmando a não utilização destes serviços pelos professores, à videoconferência com $75,5 \%$ de indicação como não utilizada; o fórum com $77,4 \%$ nesta mesma categoria, e o chat com $69,2 \%$.

\section{I DISCUSSÃO E CONCLUSÃO}

As TIC no curso de Relações Públicas da UEL estão relativamente incorporadas no ensino e nas atividades desenvolvidas pelos seus professores e percebidas pelos alunos como parcialmente inseridas nas rotinas e práticas em seu percurso no programa curricular. Os professores tem se utilizado com mais intensidade dos serviços básicos da Internet como o correio eletrônico e com um razoável uso de sites, blogs e redes sociais com seus alunos, indicando um avanço no incremento de pesquisas. Na pesquisa qualitativa alguns dos professores relataram o uso das redes sociais para compartilhamento de arquivos e matérias complementares aos assuntos dados em aula, e para disseminação dos trabalhos realizados pelos alunos. Os alunos confirmaram esta utilização das TIC, porém os percentuais tiveram uma variação para menos, perceberam uma utilização com uma frequência menor do que apontado pelos professores.

Concordando com Moran (2007), podemos afirmar que infinitas são as possibilidades de opções que a Internet apresenta, trazendo uma melhor qualidade ao planejamento das práticas do professor, incluindo o auxílio na seleção e inovação de suas metodologias e recursos didáticos de ensino. A Internet pode ajudar o professor a preparar melhor a sua aula, a ampliar as formas de ensinar, a modificar o processo de avaliação e de comunicação com o aluno e com os seus colegas.

As tecnologias podem ser excelentes recursos se os professores as conhecerem 
e utilizarem de forma adequada, tendo o domínio e conhecimento de seu uso, assim como reconhecer as formas de trabalhar com as TIC no ensino superior, e especificamente nas disciplinas da grade curricular oferecidas pelo curso de Relações Públicas, uma vez que as tecnologias, de acordo com Raposo Rivas (2002, p.50):

[...] representam, aproximam, facilitam o acesso do aluno à realidade que se aprende, mas estes, não têm sentido nenhum por si só, a não ser pelo papel que se lhes concede dentro do currículo, ou seja, em relação com as necessidades, prioridades, objetivos, conteúdos e atividades que se trabalham numa determinada área.

A integração curricular das TIC envolve diversas competências tecnológicas, técnicas, metodológicas e atitudinais que se interligam numa teia complexa de relações. De acordo com Gomes (2014, p.305):

Só com uma atitude positiva face à utilização das tecnologias em sala de aula, com o desenvolvimento de competências que permitam aos docentes usar adequadamente as ferramentas disponíveis ao serviço das aprendizagens, de uma reflexão sistemática sobre as práticas de utilização das tecnologias e o seu impacto nas aprendizagens dos alunos se poderá caminhar para uma efetiva integração curricular das TIC.

Para atender em parte esta necessidade é que fizemos ao final de nossa tese uma proposição para novos usos metodológicos com o uso das TIC, na tentativa de suprir esta lacuna que aparece na preparação dos professores e assim colaborar para a formação profissional das relações-públicas no cenário digital.

\section{REFERÊNCIAS}

Amado, J., \&Vieira, C. C. Apresentação dos dados: interpretação e teorização. In Amado, J. (Coord.). Manual de investigação qualitativa em educação (p. 377- 417). Coimbra: Imprensa da Universidade de Coimbra, 2013.

Denzin, N. K., \& Lincoln, Y. S. (Orgs.). Collecting and interpreting qualitative materials. Thousand Oaks: Sage Publications, 2003.

Gil, A. C. Como elaborar projetos de pesquisa (4a ed.). São Paulo: Atlas, 2002.

Gomes, A. C. As tecnologias da informação e comunicação no $1^{\circ}$. Ciclo do ensino básico: possibilidades e integração. Tese de doutorado, Universidade de Trás-os-Montes e Alto Douro, Vila Real, Portugal, 2014.

Lobiondo-Wood, G., \& Haber, J. Pesquisa em enfermagem: métodos, avaliação crítica e utilização. Rio de Janeiro: Guanabara Koogan, 2001.

Moran, J. M. Novas tecnologias e mediação pedagógica (13a ed.). Campinas: Papirus, 2007.

Quivy, R., \& Campenhoudt, V. Manual de investigação em ciências sociais (3a ed.). Lisboa: Gradiva, 2003. 
Raposo-Rivas, M. Novas tecnoloxías aplicadas à educación: aspectos técnicos e didácticos. Vigo: Universidad de Vigo, Portugal, 2002.

Tuckman, B. W. Manual de investigação em educação: como conceber e realizar o processo de investigação em educação. Lisboa: Fundação Calouste Gulbenkian, 2000.

Vilelas, J. Investigação: o processo de construção do conhecimento. Lisboa: Sílabo, 2009. 


\section{MOTIVAÇÃO E OUTROS FACTORES QUE INFLUENCIAM OS MÉTODOS DE ESTUDO. O CASO DE ESTUDANTES UNIVERSITÁRIOS EM ANGOLA}

\section{Laurinda Magalhães Carlos Sebastião}

Máquina Mendes

Instituto Superior de Ciências da Saúde,

Universidade Agostinho Neto, Angola

Anabela Maria de Sousa Pereira

Departamento de Educação e Psicologia da Universidade de Aveiro, Portugal

\section{Agatângelo Joaquim dos Santos Eduardo}

Instituto Superior de Ciências da Saúde,

Universidade Agostinho Neto, Angola

RESUMO: Vários programas têm procurado desenvolver competências e a promoção do sucesso académico. Acredita-se que a influência dos fatores externos, bem como as competências motivacionais, de entre outras dimensões, poderão auxiliar na trajetória académica. Apartir de um estudo quantitativo, com 286 alunos, de ambos os géneros, com médias de idade de 22.58 anos (DP=4.65), que frequentavam os primeiros anos das licenciaturas na Universidade Agostinho Neto em Angola, procurou-se verificar a influencia da Motivação e de outros factores na aquisição de competências por estudantes universitários angolanos através da recolha de informações sobre os métodos de estudo dos estudantes do Ensino Superior de Angola. Foi definida a Escala de Competências de Métodos de Estudo (ECME-ES). A ECME-ES, constituída por seis subescalas, apresentou resultados mais elevados, por ordem decrescente, as seguintes dimensões, com diferentes fatores associados: I. Motivação, II. Compreensão, III. Avaliação, IV. Organização diária da área de estudo, V. Gestão do Tempo e VI. Procrastinação, sendo verificada, tal como apontam os resultados, que Motivação tem o resultado médio mais elevado $(\mathrm{M}=4.42, \mathrm{DP}=0.62)$, com um fator associado e denominado envolvimento no processo de ensino e aprendizagem. Atenta-se que essa dimensão demonstrou valores mais elevados, sendo ela um indicador de que, para haver resultados académicos eficazes, a Motivação precisa estar efetivamente aliada ao proceso de ensino e de aprendizagem.

PALAVRAS-CHAVE: motivação, métodos de estudo, ensino superior, sucesso académico, competências.

ABSTRACT: Several programs are created to develop skills and promote academic success. It is believed that the influence of external factors, as well as motivational skills, among other dimensions, may help in the academic trajectory. From a quantitative study, with 286 students of both sexes, with a mean age of 22.58 years $(S D=4.65)$. All of the students attended the first years of the degree programs at Agostinho Neto University in Angola. We sought to verify the influence of Motivation and 
other factors in the acquisition of skills by Angolan university students through the collection of information on the methods of study of students of Higher Education in Angola. The Competency Scale of Study Methods (ECME-ES) was defined. ECME-ES, consisting of six subscales, presented higher mean scores, in descending order, the following dimensions, with different associated factors: I. Motivation, II. Understanding, III. Evaluation, IV. Daily organization of the study area, V. Time Management and VI. Procrastination. As indicated by the results, Motivation has the highest average result $(\mathrm{M}=4.42, \mathrm{SD}=0.62)$, with an associated factor called involvement in the teaching and learning process. It is important to note that this dimension has shown higher values, being an indicator that, in order to have effective academic results, Motivation needs to be effectively allied to the teaching and learning process.

KEYWORDS: motivation, study methods, higher education, academic success, skills.

\section{I INTRODUÇÃO}

A busca do conhecimento científico é hoje cada vez mais intensa, sendo notória a demanda de oportunidades no ensino superior. Em Angola, de uma única Universidade em todo País, a Universidade Agostinho Neto (UAN) até à década de 90 no século passado, regista-se hoje cerca de uma centena de instituições de ensino superior entre públicas e privadas. Assim, uma parte significativa da juventude concretizou a grande expectativa de obter a formação universitária. Porém, a aquisição de competências e habilidades profissionais deve ser acompanhada de motivação correcta e da aplicação eficiente de métodos de estudo que permita atingir o sucesso no processo de formação académica e científica.

Foi objetivo desta pesquisa perceber como a motivação e outros factores influenciam a aquisição de competências nos estudantes universitários angolanos através da recolha de informações sobre os métodos de estudo dos estudantes do Ensino Superior de Angola.

Na perspetiva de Perrenoud (1999), uma competência é uma capacidade que nos induz a agir de forma eficaz perante as situações com que nos deparamos na vida. Uma competência é apoiada no conhecimento, mas não se centra e limita somente a ele. Donaciano (2006), define competência como um certo domínio de uma pessoa para o desempenho de atividades com sucesso.

Para Gilbert e Parlier (1992 apud Jardim, 2007) é considerado competente o indivíduo que incluiu e combina de uma forma dinâmica o "saber saber", o "saber fazer" e o "saber ser", transformando-os em atividades através das quais cria evidências da sua competência e assim se adapta às " ... condições mutantes de cada contexto" (Jardim, 2007, p.78). Outro dos elementos comuns para a definição de competência é a intersubjectiva que resulta da validação, por parte de outros sujeitos, da ação competente que visa refletir a capacidade do indivíduo para reunir diferentes saberes 
no sentido da realização adequada e bem-sucedida da atividade.

Nesta investigação foi assumida a definição de competência proposta por Jardim (2007, p.79), na qual é entendida como a "... capacidade para operacionalizar um conjunto de conhecimentos, de atitudes e de aptidões numa situação concreta, de modo a ser bem sucedido". O autor acrescenta ainda que o sucesso desta operacionalização (realizada com competência) decorre do pacto efetuado entre aquele que se assume competente para a realização da atividade e um terceiro que lhe reconhece capacidade para tal.

Segundo Nimitt e Pinto (2008), a motivação proporciona os estímulos necessários para uma aprendizagem mais eficaz. E Chiavenato (2005), considera que a motivação é um estado íntimo que impele os indivíduos a comportarem-se de uma determinada maneira para alcançarem seus objetivos ou realizar suas tarefas pessoais. A motivação está interligada às forças interiores das pessoas e à forma como estas conduzem os seus comportamentos. Cada vez mais se verifica a influência da motivação na aprendizagem. Segundo Donaciano (2011), é a motivação que influenciará o envolvimento e a persistência no processo de ensino e de aprendizagem. Assim, a motivação está inteiramente ligada às competências que auxiliarão na avaliação e organização dos objetivos e metas a alcançar por parte dos estudantes.

A motivação está implícita no processo de aprendizagem, seja por parte de quem ensina, seja por parte de quem aprende. Um estudante motivado será mais atento e disciplinado, e mais interessado ao que estiver ao seu redor. Acredita-se que quanto mais motivado o estudante estiver, maior a probabilidade de organizar o seu estudo e aumentar o seu desempenho académico.

Para Nimitt e Pinto (2008), a motivação leva o aluno a empenhar-se, envolver-se e desejar estar ativamente incluído no seu processo de ensino e de aprendizagem, esforçando-se cada vez mais para aprender e evoluir.

A aprendizagem precisa envolver o uso dos saberes e estratégias pessoais para idealizar e alcançar objetivos. Neste processo, as perceções de autoeficácia são fundamentais para um resultado satisfatório (Donaciano, 2011). No processo de aprendizagem é portanto, pressuposto que os alunos tenham a responsabilidade perante as situações de organização e gestão frente as novas aprendizagens e as variáveis que possam surgir neste novo percurso.

Desde cedo, as competências de autorregulação e de autoeficácia são impulsionadores da motivação dos alunos em prol das novas aprendizagens. Piletti (2007), refere que a falta de motivação pode estar estritamente interligada à origem da não satisfação de necessidades que antecedem a aprendizagem, tais como fatores de adaptação, saudade, fome, cansaço, de entre outros.

A autorregulação é a explicitação de que os alunos não são aprendentes passivos, pelo contrário contribuem ativamente para alcançar os seus objetivos, exercitando o controlo sobre o seu processo de aprendizagem. A competência da autorregulação potencia, na aprendizagem, a execução das atividades, o delinear dos objetivos e 
motiva o estudante nos momentos de dificuldades (Veiga, 2013).

Apesar do conceito de autorregulação não estar em consenso perante os investigadores, Donaciano (2011) verificou que esta competência é fundamental para o controlo dos pensamentos, sentimentos e comportamentos, de forma a orientar o estudante num âmbito cognitivo, metacognitivo e afetivo.

Neste sentido, muitas investigações têm-se centrado na compreensão da atuação da autorregulação na prática. Os autores observam à sua atenção para alguns processos chaves, tais como a gestão do tempo, estabelecimento de objetivos, definição de estratégias de aprendizagem, monitorização dos estudos e de atribuições casuais, procura de recursos, motivação e crença da autoeficácia (Donaciano, 2011), autorregulação e autoconhecimento.

\section{I METODOLOGIA}

O instrumento incide primeiro na recolha de dados sociodemográficos da amostra e depois enfoca as habilidades e métodos de estudo dos estudantes universitários, tendo sido adaptada a escala utilizada por Donaciano (2011).

Para validar e aplicar a Escala de Competências e Métodos de Estudo (ECMEES) num contexto angolano foram usados procedimentos éticos, através de termos de autorização e consentimentos livres e esclarecidos.

O instrumento foi enviado por E-mail para o departamento da área académica que concedeu a autorização, enviou os inquéritos aos alunos que os preencheram em sala de aula com a devida autorização e supervisão dos docentes. Estes reencaminharam os questionários preenchidos para o Departamento de Assuntos Académicos, o qual devolveu aos investigadores.

À base do estudo de Donaciano (2011), foram acrescentadas as competências da "gestão do tempo" e da "procrastinação." A ECME-ES continha uma escala de Likert, com 5 níveis de concordância, em que "1" correspondia a descordo totalmente e "5" a concordo totalmente. Todas afirmações serviam para avaliar a "gestão do tempo", a "compreensão," o "comportamento diário", a "avaliação", a "procrastinação" e a "motivação".

De acordo com Hill e Hill (2009), para verificar a credibilidade e coerência das questões foi realizado um pré-teste antes da aplicação do questionário, com a participação aleatória de 10 alunos. Algumas perguntas do pré-teste foram reformuladas para melhorar a interpretação e diminuir o tempo de preenchimento da Escala. Outros 30 alunos testaram o questionário novamente, não tendo sido verificadas evidências de dificuldade no seu preenchimento.

A amostra foi de 286 alunos que frequentavam o $1^{\circ}$ ano do Instituto Superior de Ciências da Saúde e na Cidade Universitária da UAN no ano letivo 2014, sendo 148 mulheres (51.7\%) e 138 homens (48,3\%) com média de idade de 22.58 anos 
$(\mathrm{DP}=4.65)$, sendo $86.7 \%$ solteiros, $6.3 \%$ casados, $5.9 \%$ vivendo em união de facto, $0.3 \%$ divorciados. Cerca de $87,4 \%$ dos alunos proviam da Província de Luanda, 87,1\% moravam em casa/apartamento e $65,4 \%$ nunca reprovou. A nota média de acesso ao Ensino Superior foi $9.29(\mathrm{DP}=1.96)$.

O instrumento original foi reformulado após a análise da estrutura de correlação inicial dos 63 itens, tendo resultado na Tabela 1, a qual mostra a organização inicial e final, após a modificação dos itens nas escalas de Gestão do tempo (GT), Compreensão (CPR), Comportamento diário (CD), Avaliação (AV), Procrastinação (PROC) e Motivação (MOT). Na validação foram eliminados 16 itens, permanecendo 47. A eliminação destes itens teve como base os seguintes critérios: a) Carga fatorial inferior a 0.35 ; b) Carga fatorial superior a 0.35 de um item em mais que um fator; c) Correlação item-total inferior a 0.30 .

Deste modo, o iten de Gestão de tempo GT4 foi alocado na escala de Avaliação. Os itens GT5, GT6 e GT14 foram alocados na escala de procrastinação; os itens da escala de Comportamento diário CD1, CD4, foram alocados nas escalas de Gestão de tempo, e o iten CD6 foi alocado na escala da Compreensão.

\begin{tabular}{|c|c|}
\hline Item - Escala original & Item - Escala modificada \\
\hline $\begin{array}{c}\text { GT1 Escrevo objetivos diários e semanais para o } \\
\text { meu estudo. }\end{array}$ & GT \\
\hline $\begin{array}{l}\text { GT2 Estabeleço prioridades entre as diferentes } \\
\text { disciplinas a estudar e atividades que devo realizar. }\end{array}$ & GT \\
\hline $\begin{array}{l}\text { GT3 Faço um registo de todos os trabalhos e provas a } \\
\text { realizar nos próximos tempos. }\end{array}$ & GT \\
\hline $\begin{array}{l}\text { GT4 Questiono-me se o que estou a fazer permite atingir } \\
\text { os meus objetivos. }\end{array}$ & $\mathrm{AV}^{*}$ \\
\hline $\begin{array}{l}\text { GT5 No momento de estudar começo normalmente } \\
\text { por comer, ver TV ou conversar com alguém. }\end{array}$ & $\mathrm{PROC}^{*}$ \\
\hline $\begin{array}{c}\text { GT6 Tenho a tendência de fazer primeiro as tarefas } \\
\text { rápidas, fáceis e de que eu gosto mais. }\end{array}$ & $\mathrm{PROC}^{*}$ \\
\hline $\begin{array}{l}\text { GT7 Pelo menos uma vez por mês, faço um registo } \\
\text { de como estou a usar o meu tempo de estudo. }\end{array}$ & GT \\
\hline $\begin{array}{l}\text { GT8 Frequentemente tenho de dormir menos para } \\
\text { conseguir estudar todas as disciplinas. }\end{array}$ & GT \\
\hline $\begin{array}{c}\text { GT9 Planifico o meu estudo marcando um determinado } \\
\text { tempo para cada tarefa. }\end{array}$ & GT \\
\hline GT10 Escrevo uma lista de coisas a fazer todos os dias. & GT \\
\hline $\begin{array}{l}\text { GT11 Penso frequentemente que me devia organizar } \\
\text { mais. }\end{array}$ & GT \\
\hline $\begin{array}{c}\text { GT12 Analiso os registos das aulas e procuro maneiras } \\
\text { de simplificar ou melhorá-los. }\end{array}$ & GT \\
\hline $\begin{array}{c}\text { GT13 A minha área de estudo devia estar mais } \\
\text { arrumada. }\end{array}$ & GT \\
\hline $\begin{array}{l}\text { GT14 Socialização (por exemplo, facebook) impedem- } \\
\text { me às vezes de me concentrar nos estudos. }\end{array}$ & PROC* \\
\hline $\begin{array}{l}\text { GT15 As pessoas dizem-me frequentemente que eu } \\
\text { devia parar um bocado, relaxar e estudar menos. }\end{array}$ & GT \\
\hline
\end{tabular}


GT16 Normalmente durmo o suficiente, faço exercício físico regular e como comida saudável.

GT17 Sinto muita tensão e pressão enquanto estudo e tenho dificuldades em lidar bem com isso.

GT18 Sinto que não tenho tempo suficiente para descansar ou divertir-me.

CPR1 Deteto as palavras-chave de um texto.

CPR2 Nas aulas, fico atento(a) ao professor e à turma para entender melhor as matérias.

CPR3 Quando estudo faço anotações, resumos ou esquemas.

CPR

CPR4 Capto as principais ideias de um texto.

CPR

CPR5 Refaço os exercícios e releio os apontamentos para entender a matéria

CPR6 Memorizo os conteúdos através da leitura.

CPR

CPR7 Reescrevo as partes importantes de um texto ou anotações à medida que estudo.

CPR

CPR8 Gosto de esclarecer as dúvidas que tenho à medida que estudo as matérias.

CPR

CPR9 Anoto aspetos que não compreendo para depois pedir ajuda ou voltar a eles e superar as dificuldades.

CPR10 Para participar melhor das aulas, estudo o conteúdo antecipadamente.

CPR

CPR11 Relaciono o conteúdo da aula com

aprendizagens anteriores a fim de compreender melhor os conceitos.

CPR

CPR12 Estudo a matéria numa sequência que facilite a minha compreensão.

CPR

CD1 Elaboro um horário de estudo que procuro seguir diariamente.

CD2 Em geral sou assíduo às aulas.

CD3 Tenho o meu material de estudo organizado por disciplinas

CD4 Consigo ter tempo suficiente para estudar todas as matérias.

$\mathrm{GT}^{*}$

CD5 Quando necessário procuro um local reservado para estudar.

CD6 Nas aulas concentro-me para entender a explicação dos professores. interromper.

CD8 Leio sempre os textos e faço os exercícios sugeridos pelos professores.

AV1 Quando vou concluir o estudo de uma matéria verifico se entendi tudo.

AV2 Consigo antecipar benefícios futuros do esforço que dedico ao meu estudo.

AV3 Confronto os meus conhecimentos com os dos colegas para aprofundar o meu domínio das matérias no meu rendimento académico. 


\begin{tabular}{|c|c|}
\hline Item - Escala original & Item - Escala modificada \\
\hline $\begin{array}{c}\text { AV5 Avalio o meu desempenho nas provas para definir } \\
\text { quanto devo estudar. }\end{array}$ & AV \\
\hline $\begin{array}{l}\text { AV6 Procuro conhecer como os professores elaboram as } \\
\text { provas para adequar o meu estudo. }\end{array}$ & AV \\
\hline $\begin{array}{l}\text { AV7 Preparo-me para o teste antecipando questões que } \\
\text { possam ser colocadas sobre a matéria. }\end{array}$ & AV \\
\hline $\begin{array}{l}\text { AV8 Primeiro leio a prova para ter uma ideia do seu } \\
\text { conteúdo e só depois respondo às questões. }\end{array}$ & AV \\
\hline AV9 Sinto satisfação com a forma como estudo. & AV \\
\hline $\begin{array}{c}\text { PROC1 Quando o professor manda fazer uma tarefa } \\
\text { faço-a imediatamente. }\end{array}$ & PROC \\
\hline $\begin{array}{l}\text { PROC2 Normalmente deixo de estudar disciplinas que } \\
\text { me são desagradáveis. }\end{array}$ & PROC \\
\hline $\begin{array}{c}\text { PROC3 Faço a revisão do conteúdo das aulas todos os } \\
\text { dias. }\end{array}$ & PROC \\
\hline $\begin{array}{c}\text { PROC4 Adio para o dia seguinte o que deveria estudar } \\
\text { hoje. }\end{array}$ & PROC \\
\hline $\begin{array}{l}\text { PROC5 Tenho tendência de esperar até ao último minuto } \\
\text { para começar a estudar. }\end{array}$ & PROC \\
\hline $\begin{array}{l}\text { PROC6 Frequentemente tenho de esperar a disposição } \\
\text { certa ou a altura certa para estudar. }\end{array}$ & PROC \\
\hline $\begin{array}{l}\text { PROC7 Perco-me em tantas coisas/atividades que não } \\
\text { me sobra tempo para estudar para as provas. }\end{array}$ & PROC \\
\hline $\begin{array}{c}\text { PROC8 Preocupo-me frequentemente com a } \\
\text { possibilidade de ter tomado uma má decisão relativa aos } \\
\text { estudos. }\end{array}$ & PROC \\
\hline $\begin{array}{l}\text { MOT1 Motivo-me para continuar a estudar esforçando- } \\
\text { me para obter melhores resultados. }\end{array}$ & MOT \\
\hline $\begin{array}{c}\text { MOT2 Estabeleço metas de estudo de acordo com as } \\
\text { necessidades das matérias. }\end{array}$ & MOT \\
\hline $\begin{array}{l}\text { MOT3 Imagino exemplos de aplicação prática para um } \\
\text { assunto se isso me motiva a estudá-lo melhor. }\end{array}$ & MOT \\
\hline $\begin{array}{c}\text { MOT4 Com frequência distraio-me quando não consigo } \\
\text { compreender as matérias. }\end{array}$ & MOT \\
\hline $\begin{array}{l}\text { MOT5 Esforço-me por estudar mais intensamente um } \\
\text { conteúdo mais difícil. }\end{array}$ & MOT \\
\hline $\begin{array}{c}\text { MOT6 Não consigo estudar certos conteúdos quando } \\
\text { eles não me interessam. }\end{array}$ & MOT \\
\hline $\begin{array}{c}\text { MOT7 O meu estudo está a ser importante para } \\
\text { desenvolver competências para o meu futuro } \\
\text { profissional. }\end{array}$ & MOT \\
\hline $\begin{array}{l}\text { MOT8 Esforço-me por obter os melhores resultados } \\
\text { académicos possíveis. }\end{array}$ & MOT \\
\hline
\end{tabular}

Tabela 1- Instrumento ECME-ES após análise exploratória e apreciação teórica dos 63 itens.

O tratamento estatístico foi feito com o SPSS (v.22, IBM Corporation, 2013). A caracterização da amostra foi realizada com recurso ao cálculo de medidas descritivas como média, desvio padrão, frequências ou percentagens.

A validação do instrumento foi feita com análises de fiabilidade e validade (Maroco, 2003; Field, 2005). 
Neste estudo considerou-se como valor mínimo do alfa de Cronbach 0.60 (Pestana e Gageiro, 2008) e correlação item-total acima de 0.30 (Tabachnick e Fidell, 2007).

Para analisar a validade foi utilizada uma Análise em Componentes Principais (ACP), com recurso a uma técnica de rotação ortogonal Varimax, cujo objetivo é atribuir a cada item uma carga fatorial "exclusiva" a um só fator (Field, 2005). Esta carga fatorial diz respeito à correlação existente entre o fator e o item que pode variar entre -1 e 1, em que o 0 representa ausência de covariância. Quanto mais o valor de correlação se aproximar dos extremos -1 ou 1 maior será a ligação entre esse item com o fator. Neste estudo foi considerado como critério de inclusão de um item no fator à obtenção de uma carga fatorial acima de 0.35 (Schmitt, 2011).

Um outro importante princípio da validação é o da extração de fatores baseada em valores próprios superiores a 1 (Pestana e Gageiro, 2008). Os valores próprios dizem respeito à quantidade de variância explicada extraída com cada fator. $O$ total de variância explicada diz respeito à quantidade de variabilidade explicada por todos os fatores cujo valor próprio seja superior a 1, considerando-se este como o critério (Pestana e Gageiro, 2008). O somatório das variâncias explicadas de todos os fatores deve ser pelo menos 50\% (Maroco, 2003; Field, 2005). O screeplot, diagrama que projeta a variância explicada/valores próprios por cada fator (eixo yy), pelo número de fatores extraídos (eixo xx), foi também analisado como método de seleção do número de fatores.

Para a realização da ACP foram tidos em conta os seus dois pressupostos fundamentais: a) O teste Kaiser-Meyer-Olkin (KMO) permite conhecer a proporção da variância dos dados que pode ser considerada comum a todas as variáveis. Logo, que pode ser atribuída a um fator comum. O critério considerado foi $\mathrm{KMO}>0.60$ (Maroco, 2003; Field, 2005); b) O teste de esfericidade de Bartlett (BTS) que testa se a matriz de correlação é uma matriz identidade $(\mathrm{H} 0)$, o que indica se há ou não correlação entre os dados. Este teste rejeita a hipótese nula se $\mathrm{p}<0.05$, indicando assim evidências da existência de correlações aceitáveis entre as variáveis/itens (Diamantopoulos e Siguaw, 2000; Field, 2005).

$\mathrm{Na}$ análise de fiabilidade e validade da amostra foram invertidos os itens cuja formulação era contrária à dos restantes, permitindo assim medir cada fator no sentido positivo. Deste modo a solução final contou com alguns itens invertidos: itens 6 e 7 na escala de gestão do tempo e itens 3-8 na escala de procrastinação.

\section{I RESULTADOS E DISCUSSÃO}

Os resultados abaixo mostram que a fiabilidade e validade das tabelas analisadas, que correspondem aos construtos, nomeadamente GT, CPR, CD, AV, PROC e MOT são aceitáveis, permitindo concluir que as propriedades psicométricas do instrumento 
são apropriadas. Todas as escalas cumpriram os critérios KMO> .60 e BTS, p<.001.

Quanto à variância explicada, apenas na avaliação este valor ficou abaixo de $50 \%$, porém, próximo deste critério (47.39\%). Todas as cargas fatoriais foram superiores a .35, sugerindo correlação adequada entre os itens e o respetivo fator.

Não foi encontrada qualquer carga fatorial abaixo de .40. Ao nível da consistência interna foram detetados valores de alfa de Cronbach abaixo de .60 no Comportamento diário, com .50 e Procrastinação com .54, conforme a Tabela 2. Todos os restantes foram iguais ou superiores a 0.60 .

Na subescala de comportamento diário foi encontrado um único fator designado: organização diária da área de estudo $(\mathrm{M}=3.91, \mathrm{DP}=0.71)$. Os resultados deste estudo apontam para a importância do local escolhido, nomeadamente na necessidade de demarcação de um espaço próprio para o estudo que deve oferecer boas condições de conforto, iluminação, higiene, ventilação, evitando também espaços com muitos estímulos visuais e sonoros.

\begin{tabular}{l|c}
\hline $\begin{array}{c}\text { DESCRIÇÕO DOS ITENS DA SUBESCALA DE } \\
\text { COMPORTAMENTO DIÁRIO }\end{array}$ & CARGA FATORIAL \\
\hline $\begin{array}{l}\text { 1. Tenho o meu material de estudo organizado por } \\
\text { disciplinas }\end{array}$ & 0.74 \\
2. Antes de começar a estudar verifico se tenho \\
todos os materiais necessários para não ter que \\
interromper. \\
$\begin{array}{l}\text { 3. Leio sempre os textos e faço os exercícios } \\
\text { sugeridos pelos professores. }\end{array}$ \\
$\quad$ a cronbach \\
Variância explicada & 0.70 \\
\end{tabular}

$\mathrm{kmo}=0.60, \mathrm{bts}, \mathrm{p}<.001$

Tabela 2- Análises de fiabilidade e validade para o fator de Comportamento diário

Quanto à procrastinação foram encontrados três fatores: autorregulação $(\mathrm{M}=$ $3.59, \mathrm{DP}=0.93)$, manifestação da procrastinação $(\mathrm{M}=2.96, \mathrm{DP}=0.87)$ e procrastinação no estudo diário $(\mathrm{M}=3.66$, $\mathrm{DP}=0.80)$.

Esses resultados, se harmonizam com as pesquisas de Sampaio, Polydoro e Rosário (2012), sobre a autorregulação e a procrastinação em estudantes universitários, como forma de colaborar com o processamento superficial das informações e compreensão daquilo que se pretende aprender, bem como, dum desempenho abaixo do esperado.

Segundo as referidas autoras, uma relação negativa e estatisticamente significante entre a autorregulação da aprendizagem e a procrastinação nos estudos, dá indícios, de que o estudante que procrastina, tem dificuldade em utilizar as suas estratégias de 
autorregulação da aprendizagem.

Quanto ao resultado da procrastinação no estudo diário, os resultados de tais investigadoras também apresentam correlações negativas e significantes.

\begin{tabular}{|c|c|c|c|}
\hline \multirow{2}{*}{$\begin{array}{c}\text { DESCRIÇÃO DOS ITENS DA SUBESCALA DE } \\
\text { PROCRASTINAÇÃO }\end{array}$} & \multicolumn{3}{|c|}{ CARGA FATORIAL } \\
\hline & $F 1$ & F2 & F3 \\
\hline $\begin{array}{l}\text { 1. Quando o professor manda fazer uma tarefa faço-a } \\
\text { imediatamente }\end{array}$ & .74 & & \\
\hline $\begin{array}{l}\text { 2. Faço a revisão do conteúdo das aulas todos os } \\
\text { dias. }\end{array}$ & .69 & & \\
\hline $\begin{array}{l}\text { 3. Tenho a tendência de fazer primeiro as tarefas } \\
\text { rápidas, fáceis e de que eu gosto mais. }\end{array}$ & & .66 & \\
\hline $\begin{array}{l}\text { 4. Frequentemente tenho de esperar a disposição } \\
\text { certa ou a altura certa para estudar. }\end{array}$ & & .65 & \\
\hline $\begin{array}{l}\text { 5. No momento de estudar começo normalmente por } \\
\text { comer, ver tv ou conversar com alguém. }\end{array}$ & & .63 & \\
\hline $\begin{array}{l}\text { 6. Perco-me em tantas coisas/atividades que não me } \\
\text { sobra tempo para estudar para as provas. }\end{array}$ & & & .68 \\
\hline $\begin{array}{l}\text { 7. Tenho tendência de esperar até ao último minuto } \\
\text { para começar a estudar. }\end{array}$ & & & .64 \\
\hline $\begin{array}{l}\text { 8. Adio para o dia seguinte o que deveria estudar } \\
\text { hoje. }\end{array}$ & & & .62 \\
\hline a cronbach & & .54 & \\
\hline Variância explicada & & 53.87 & \\
\hline
\end{tabular}

$\mathrm{kmo}=.61, \mathrm{bts}, \mathrm{p}<.001$

Tabela 3- Análises de fiabilidade e validade para o fator de Procrastinação

Os fatores em cada escala foram nomeados de acordo com os itens que neles foram alocados devido à carga fatorial elevada. Os fatores pertencentes à subescala de gestão do tempo que foram nomeados como: organização do estudo $(\mathrm{M}=3.40$, $\mathrm{DP}=0.79)$, gestão das atividades diárias do estudo $(\mathrm{M}=3.00, \mathrm{DP}=0.91)$, organização da área de estudo $(\mathrm{M}=4.01, \mathrm{DP}=0.82)$ e planeamento do estudo $(\mathrm{M}=3.22, \mathrm{DP}=0.85)$.

Estes fatores estão relacionados com a utilização adequada do tempo, com os objetivos definidos pelos próprios alunos, bem como os critérios estabelecidos para alcançar e avaliar as suas próprias aprendizagens, de forma a gerir e valorizar seu tempo de maneira eficaz (Ramos, 2013).

Os resultados concordam com os de Costa (2005) que refere a relevante importância do planeamento individual, no sentido de que os estudantes organizem um plano de atividades diárias e/ou semanais no qual estejam incluídos não só as tarefas a serem desenvolvidas, mas também a relação dos exames com as datas e os resultados, bem como a definição das horas de estudo semanais, para que assim, 
possam organizar-se e gerir melhor seu tempo, buscando resultados satisfatórios.

No estudo de Virtanen, Nevgi e Niemi (2013), os resultados apontam para uma relação importante entre a gestão do tempo e outras estratégias de autorregulação como autocontrolo, autoavaliação e busca ativa por ajuda com vista na resolução de problemas, fatores igualmente preditores do sucesso académico em estudantes do Ensino Superior.

De acordo com Nadinloyi et al. (2013), as competências de gestão de tempo podem ser treinadas, o que, dada a relação entre esta dimensão do comportamento e o desempenho académico, se revela como fator importante a ter em conta para o sucesso em estudantes do Ensino Superior.

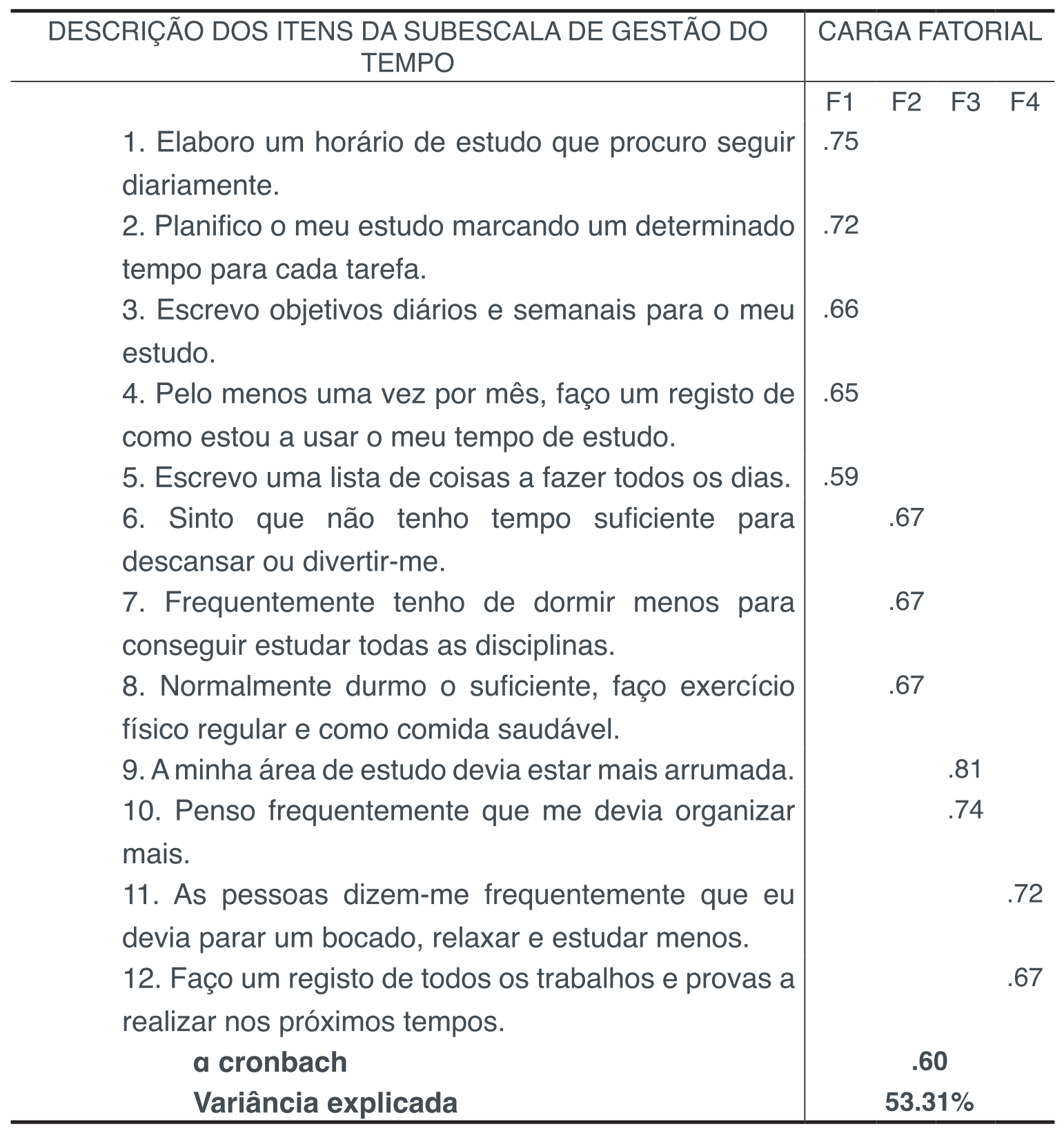

$\mathrm{kmo}=.70, \mathrm{bts}, \mathrm{p}<.001$

Tabela 4- Análises de fiabilidade e validade para o fator de Gestão do Tempo

$\mathrm{Na}$ subescala de compreensão foram encontrados os fatores: organização da informação $(\mathrm{M}=4.22, \mathrm{DP}=0.55)$, compreensão em sala de aula $(\mathrm{M}=3.90, \mathrm{DP}=0.66) \mathrm{e}$ 
sistematização da informação $(\mathrm{M}=4.06, \mathrm{DP}=0.67)$. Neste trabalho, foram verificadas semelhanças ao estudo de Donaciano e Almeida (2011), com estudantes universitários de Moçambique, onde se observam as atitudes de compreensão e organização da informação que se apresentam como estratégias que o aluno aplica para facilitar a sua aprendizagem e incrementar o seu desempenho escolar.

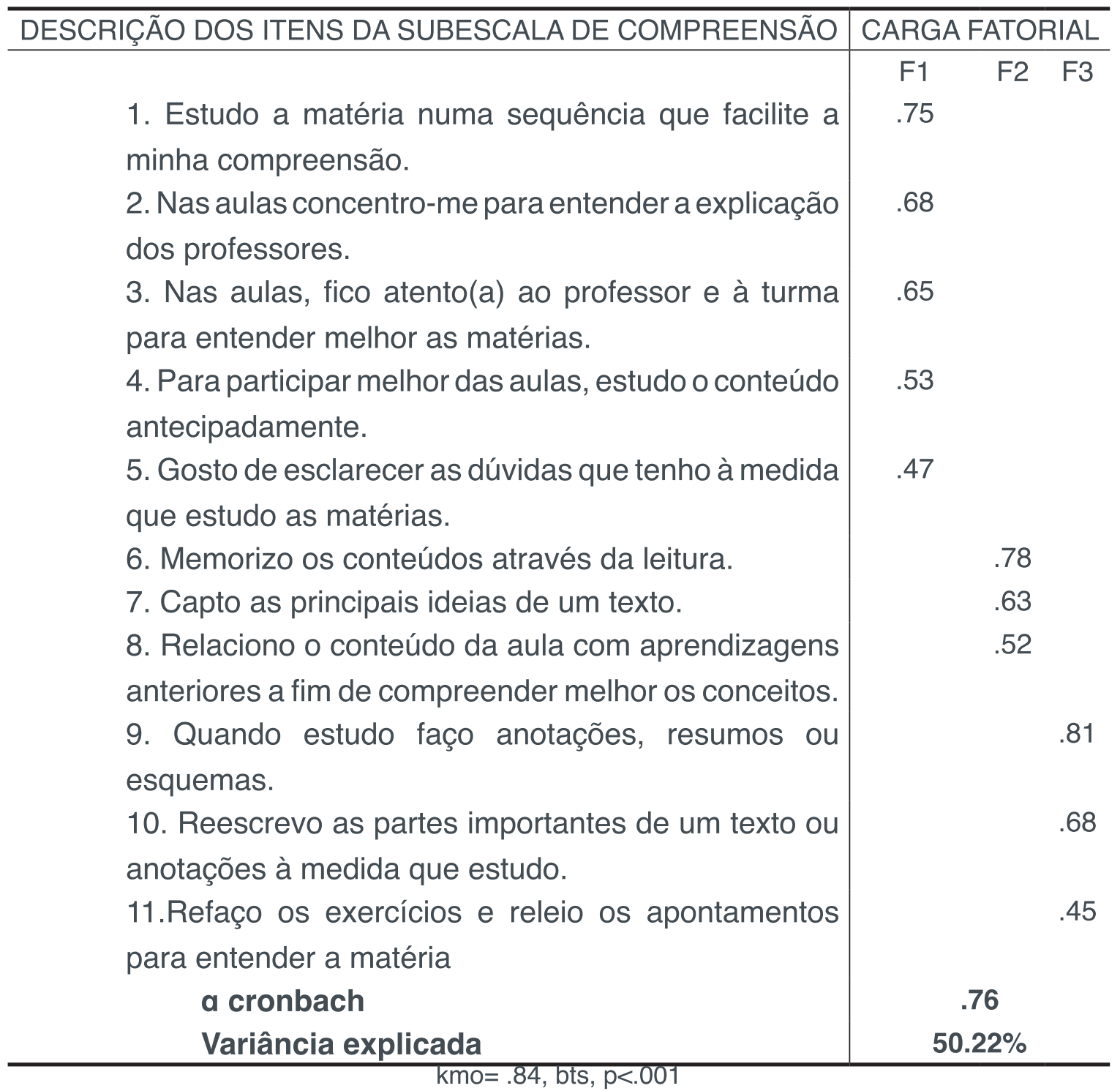

Tabela 5- Análises de fiabilidade e validade o fator de Compreensão

A subescala da motivação teve um único fator denominado envolvimento no processo de ensino e aprendizagem $(\mathrm{M}=4.42$, $\mathrm{DP}=0.62)$. A motivação demonstrou valores mais elevados, indicando que, para haver um estudo eficaz, a motivação precisa estar aliada às outras competências.

Segundo Paulino, Sá e Silva (2015), em seu estudo sobre a autorregulação da motivação, a motivação é considerada um tema essencial quando se reflete sobre a aprendizagem e o sucesso escolar, bem como a autorregulação da motivação, já que esta é identificada na aprendizagem como um aspeto fundamental para as competências de autorregulação da aprendizagem. 
As competências motivacionais são evidenciadas pelos fatores e características pessoais, por isso são interligadas aos objetivos, interesses, expectativas, vontades e emoções da própria pessoa e nessa perspetiva, o auto conhecimento e a auto aceitação são imprescindíveis neste âmbito. Por outro lado, os fatores motivacionais podem ser extrínsecos aos alunos, como apoio dos familiares e respostas positivas dos professores. Segundo Moreira et al. (2013), os estudantes do Ensino Superior com desempenho académico mais baixo são também os que estão menos motivados.

\begin{tabular}{l|c}
\hline DESCRIÇÃO DOS ITENS DA SUBESCALA DE MOTIVAÇÃO & CARGA FATORIAL \\
\hline & F1 \\
1. Esforço-me por obter os melhores resultados & .78 \\
académicos possíveis. & .75 \\
2. O meu estudo está a ser importante para desenvolver & \\
competências para o meu futuro profissional. & .77 \\
3. Motivo-me para continuar a estudar esforçando-me \\
para obter melhores resultados. \\
a cronbach \\
Variância explicada \\
\hline
\end{tabular}

$\mathrm{kmo}=.84, \mathrm{bts}, \mathrm{p}<.001$

Tabela 6- Análises de fiabilidade e validade para o fator de Motivação

Na subescala de avaliação foram identificados três fatores: atitude face à avaliação $(\mathrm{M}=3.90, \mathrm{DP}=0.66)$, preparação de exames $(\mathrm{M}=4.12, \mathrm{DP}=0.61)$ e autoanálise face ao desempenho $(\mathrm{M}=3.85$, $\mathrm{DP}=0.85)$, que podem ser observados de forma interligada.

Neste aspeto, Ramos (2013) afirma que a preparação do aluno para a avaliação e a sua atitude frente a esta é crucial para o seu desempenho, pois a sua preparação prévia poderá libertá-lo da sensação de ansiedade, acarretando uma maior confiança frente ao teste, contrariamente, aqueles estudantes que se prepararam de forma insatisfatória poderão apresentar maiores níveis de ansiedade e chegarão ao teste sem confiança na sua capacidade de aprovação.

Neste estudo a avaliação é tida como uma componente importante das competências e métodos de estudo. Para Broadbent e Poon (2015), a avaliação pode funcionar como uma estratégia de autorregulação, responsável pela criação de balizas visando o alcance de objetivos, e controlo de processos com vista ao sucesso académico. Segundo Virtanen, Nevgi e Niemi (2013), a avaliação é uma componente essencial para alcançar o sucesso académico e correlaciona-se de forma forte com a persistência com vista ao sucesso, o desenvolvimento de estratégias de aprendizagem adequadas, expectativas de sucesso, autoeficácia e motivação intrínseca. A avaliação é deste modo, uma ferramenta importante a ter em conta para a melhoria do desempenho académico e um construto chave a ser avaliado nos alunos do Ensino Superior. 


\begin{tabular}{|c|c|c|c|}
\hline \multirow[t]{2}{*}{ DESCRIÇÃO DOS ITENS DA SUBESCALA DE AVALIAÇÃO } & \multicolumn{3}{|c|}{ CARGA FATORIAL } \\
\hline & $\mathrm{F} 1$ & $\mathrm{~F} 2$ & F3 \\
\hline 1. Sinto satisfação com a forma como estudo. & .66 & & \\
\hline $\begin{array}{l}\text { 2. Preparo-me para o teste antecipando questões que } \\
\text { possam ser colocadas sobre a matéria. }\end{array}$ & .65 & & \\
\hline $\begin{array}{l}\text { 3. Consigo antecipar benefícios futuros do esforço que } \\
\text { dedico ao meu estudo. }\end{array}$ & .53 & & \\
\hline $\begin{array}{l}\text { 4. Quando vou concluir o estudo de uma matéria } \\
\text { verifico se entendi tudo. }\end{array}$ & .48 & & \\
\hline $\begin{array}{l}\text { 5. Primeiro leio a prova para ter uma ideia do seu } \\
\text { conteúdo e só depois respondo às questões. }\end{array}$ & & .70 & \\
\hline $\begin{array}{l}\text { 6. Avalio o meu desempenho nas provas para definir } \\
\text { quanto devo estudar. }\end{array}$ & & .65 & \\
\hline $\begin{array}{l}\text { 7. Consigo identificar as causas dos resultados fracos } \\
\text { no meu rendimento académico. }\end{array}$ & & .62 & \\
\hline $\begin{array}{l}\text { 8. Questiono-me se o que estou a fazer permite atingir } \\
\text { os meus objetivos. }\end{array}$ & & .40 & \\
\hline $\begin{array}{l}\text { 9. Confronto os meus conhecimentos com os dos } \\
\text { colegas para aprofundar o meu domínio das matérias }\end{array}$ & & & .78 \\
\hline $\begin{array}{l}\text { 10. Procuro conhecer como os professores elaboram } \\
\text { as provas para adequar o meu estudo. }\end{array}$ & & & .70 \\
\hline a cronbach & & .63 & \\
\hline Variância explicada & & $47.39 \%$ & \\
\hline
\end{tabular}

$$
\mathrm{kmo}=.71, \mathrm{bts}, \mathrm{p}<.001
$$

Tabela 7- Análises de fiabilidade e validade para o fator de Avaliação

Os resultados médios mais elevados foram encontrados na Tabela 8, pela Motivação $(M=4.42, D P=0.62)$, seguidos pela Compreensão $(M=4.06, D P=0.49)$, Avaliação $(M=3.96, D P=0.50)$, Organização diária da área de estudo $(M=3.91, D P=$ $0.71)$, Gestão do Tempo ( $M=3.41$, $D P=0.47)$ e Procrastinação $(M=3.40$, $D P=0.60)$.

\begin{tabular}{c|ccc}
\hline SUBESCALA & FATOR & M & DP \\
\hline GESTÃO DO TEMPO & Organização do estudo & 3.40 & 0.79 \\
& Gestão das atividades diárias de estudo & 3.00 & 0.91 \\
& Organização da área de estudo & 4.01 & 0.82 \\
& Planeamento do estudo & 3.22 & 0.85 \\
& Gestão do tempo (total) & 3.41 & $\mathbf{0 . 4 7}$ \\
COMPREENSÃO & Organização da informação & 4.22 & 0.55 \\
& Compreensão em sala de aula & 3.90 & 0.66 \\
& Sistematização da informação & 4.06 & 0.67 \\
& Compreensão (total) & 4.06 & $\mathbf{0 . 4 9}$
\end{tabular}




\begin{tabular}{c|ccc}
$\begin{array}{c}\text { COMPORTAMENTO } \\
\text { DIÁRIO } \\
\text { AVALIAÇÃO }\end{array}$ & Organização diária da área de estudo (total) & 3.91 & $\mathbf{0 . 7 1}$ \\
& Atitude face à avaliação & 3.90 & 0.66 \\
PROCRASTINAÇÃOO & Preparação de exames & 4.12 & 0.61 \\
& Autoanálise face ao desempenho & 3.85 & 0.85 \\
& Avaliação (total) & 3.96 & 0.50 \\
& Autorregulação & 3.59 & 0.93 \\
MOTIVAÇÃO & Manifestação da procrastinação & 2.96 & 0.87 \\
& Procrastinação no estudo diário & 3.66 & 0.80 \\
& Procrastinação (total) & 3.40 & $\mathbf{0 . 6 0}$ \\
& Envolvimento no processo ensino & 4.42 & $\mathbf{0 . 6 2}$ \\
\hline
\end{tabular}

Tabela 8- Resultados médios para os fatores criados

\section{I CONSIDERAÇÕES FINAIS}

Os resultados da ECME-ES permitiram identificar 6 fatores fundamentais para a avaliação das competências e métodos de estudo dos estudantes do Ensino Superior: GT, CPR, CD, AV, PROC e MOT.

$A$ adaptação de uma escala, numa dimensão transcultural, compreende uma série de passos para redefinição dos itens que se inserem devidamente no contexto a ser validado. Após a adaptação e validação da ECME-ES, acreditamos que é possível, enquanto docentes, aprimorarmos alguns aspetos em sala de aula para apresentarmos diferentes métodos de estudo, de acordo com as necessidades referidas pelos estudantes do primeiro ano, visando incentivar os alunos a terem hábitos de estudo mais eficazes.

Através dos testes estatísticos realizados, verificou-se que a fiabilidade do ECMEES é aceitável e que as propriedades psicométricas são apropriadas. Isso revelou ser um instrumento confiável e válido para a avaliação da capacidade de autodisciplina e de autorregulação, nas novas exigências dos alunos universitários, bem como do estudo da procrastinação e indicou uma boa consistência interna.

Os resultados obtidos serviram para construir o Programa de Intervenção sobre Métodos de Estudo no Ensino Superior Angolano (PIME-ESA) para jovens universitários e possibilitar uma recolha de dados fidedignos à realidade de Angola.

No entanto, torna-se necessário aprofundar a reflexão e produzir conhecimento sobre o desenvolvimento da capacidade de autodisciplina e de autorregulação, nas novas exigências dos alunos universitários ao nível do ensino e da aprendizagem.

Para futuros estudos, recomendamos a utilização desta escala para a avaliação das competências e dos métodos de estudo dos estudantes, como forma de autoavaliação das principais necessidades dos próprios alunos, ou como fonte de pesquisa e recolha de dados dos investigadores. É nosso desejo que estas conclusões visem a produção de maior e melhor auxílio para os estudantes de outras instituições de Ensino Superior 
angolanas, de forma a analisar e captar o fenômeno que se pretende medir.

\section{REFERÊNCIAS}

Broadbent, J.; Poon, W. L.. Self-regulated learning strategies \& academic achievement in online higher education learning environments: A systematic review. The Internet and Higher Education, n. 27, p,1-13, 2015.

Chiavenato, I.. Comportamento organizacional. 2 ed. Editora Campus, 2005,

Costa, S.. Aprender a estudar. Dôssier de apoio ao programa de promoção de hábitos de trabalho e métodos de estudo. Coimbra: Direção Geral de Educação do Centro, 2005.

Diamantopoulos, A.; Siguaw, J. A. Introducing LISREL. London: Sage Publications, 2000.

Donaciano, B. A Formação de professores primários em Moçambique: Desenvolvimento da competência docente dos formandos durante o estágio, no Modelo $10^{a}+1+1$ (estudo de caso na Província de Tete). Originalmente apresentada como Dissertação de Mestrado. PUC/SP em convénio com a Universidade Pedagógica de Moçambique, 2006.

Donaciano, B. Vivências académicas, métodos de estudo e rendimento escolar em estudantes da Universidade Pedagógica. Tese de Doutoramento em Ciências de Educação: Universidade do Minho, 2011.

Donaciano, B.; Almeida, L. S.. Estratégias de estudo: Auscultando os estudantes da Universidade de Moçambique sobre as suas aprendizagens. In: Silva, J. L. C.; Vieira, F.; Oliveira, C. C.; Morgado, J. C. et al. (Orgs.). Actas do Congresso Ibérico sobre Pedagogia para Autonomia / $5^{\circ}$ encontro do GT-PA, p. 285-297, ISBN, 978-989-8525-02-4, Universidade do Minho, 2011.

Field, A. Discovering Statistics Using SPSS. 2nd ed. London: Sage, 2005.

Hill, M.; Hill, A. Investigação por questionário. 2 ed. Lisboa: Edições Sílabo, 2009.

Jardim, J. Programa desenvolvimento de competências pessoais e sociais: Estudo para a promoção do sucesso académico. Tese de Doutoramento. Universidade de Aveiro: Aveiro, 2007. Maroco, J. Análise estatística - com utilização do SPSS. Lisboa: Edições Sílabo, 2003.

Moreira, P.; Dias, P.; Vaz, F.; Vaz, J. Predictors of academic performance and school engagement - Integrating persistence, motivation and study skills perspectives using person-centered and variable-centered approaches. Learning and Individual Differences, 2013. n.24, p. 117-125.

Nadinloyi, K. B.; Hajloo, N.; Garamaleki, N. S.; Sadeghi, H. The Study Efficacy of Time Management Training on Increase Academic Time Management of Students. Procedia - Social and Behavioral Sciences, 2013, n.84, p. 134-138.

Nimitt, D. B.; Pinto, C. B. G. C. Formação Pedagógica: Expectativas e Motivação ligadas à Prática Pedagógica do Professor. Univ. Hum., 2008 n.5 vol.1-2, p.159-180.

Paulino, P.; Sá, I.; Silva, A.. Autorregulação da Motivação: Crenças e Estratégias de Alunos Portugueses do $7^{\circ}$ ao $9^{\circ}$ Ano de Escolaridade. Psicologia: Reflexão e Crítica, 2015 n.28 vol.3, p. 574-582

Perrenoud, P. Construir as competências a partir da Escola. Porto Alegre: Artmed, 1999. Pestana, M. H.; Gageiro, J. G. Análise de dados para ciências sociais: a complementaridade do SPSS. 5 ed. Lisboa: Sílabo, 2008. 
Piletti, C. Didática Geral. 23 ed. São Paulo: Ática, 2007.

Ramos, S. I. V. Hábitos e Métodos de estudo dos alunos do Ensino Superior. Revista Psicologia, 2013.

Sampaio, R. K. N.; Polydoro, S. A. J.; Rosário, P. S. L. F. Autorregulação da aprendizagem e a procrastinação académica em estudantes universitários. Periódicos UFPEL, 2012, n.42, p. 119 142.

Schmitt, T. A. Current methodological considerations in exploratory and confirmatory factor analysis. Journal of Psychoeducational Assessment, 2011, n.29, vol.4, p. 304-321.

Tabachnick, B. G.; Fidell, L. S. Using multivariate statistics. 5 ed. Boston: Pearson/Allyn \& Bacon, 2007.

Veiga, H. Psicologia da Educação Teoria, Investigação e Aplicação Envolvimento dos Alunos na Escola. Lisboa: Climepsi, 2013.

Virtanen, P.; Vevgi, A.; Niemi, H.. Self-regulation in higher education: students' motivational, regulational and learning strategies, and their relationships to study success. Studies for the Learning Society, 2013, n.3, vol.1-2, p. 20-36. 


\section{A ARTE DE VER: VAMOS FOTOGRAFAR?}

Elaine Simões Romual Rebeca Centro de Investigação em Estudos da Criança Instituto de Educação - Universidade do Minho

(Portugal)

Braga - Portugal

Maria de Lurdes Dias de Carvalho Centro de Investigação em Estudos da Criança Instituto de Educação - Universidade do Minho

(Portugal)

Braga - Portugal

RESUMO: Cada pessoa tem a sua forma de olhar e ver as coisas que a cerca. O treino na arte de olhar amplia nossa percepção. O objetivo deste trabalho foi relacionar experiências estéticas de estudantes focalizadas entre o senso estético e $\mathrm{o}$ ato de ver utilizando o registro fotográfico. A pesquisa cinge-se a um estudo exploratório de carácter descritivo e interpretativo. A análise permitiu concluir que numa contemplação direcionada, a relação do sujeito com o objeto passará pela sua percepção comum e poderá levá-lo a uma percepção mais seletiva, a uma percepção estética, tornando possível o refinamento estético e cultural.

PALAVRAS-CHAVE: olhar, ver, estética, percepção, senso estético.

ABSTRACT: Each person has his way of looking and seeing the things that surround him.
The training in the art of looking enlarges our perception. The objective of this work was to relate aesthetic experiences of students focused between the esthetic sense and the act of seeing using photographic record. The research is limited to an exploratory study of descriptive and interpretative nature. The analysis allowed to conclude that in a directed contemplation, the relation of the subject with the object will pass through its common perception and can take it to a more selective perception, to an aesthetic perception, making possible the aesthetic and cultural refinement.

KEYWORDS: to look, to see, aesthetics, perception, aesthetic sense.

\section{I APRENDENDO A OLHAR: VAMOS} FOTOGRAFAR?

Fotografia é uma coisa tangível, você captura, você olha para ela. É algo semelhante à memória (SALGADO, 2017)

Refletir sobre o ato de OLHAR e o de VER nos convida a pensar que VER não é tão simples assim. O VER nos leva a um ato além do que a retina reflete, é uma comunicação com o cérebro e todas as sinapses que este momento acarreta. 
A sociedade na qual vivemos hoje está tão focada na busca de diferentes objetivos que acaba por ficar cega e alheia à vida (natural e construída). Propostas e resultados, ... trabalho, ... busca e ideal, ... objetivos, ... futuro, ... estas são algumas das palavras que nos rodeia no cotidiano e, inconscientemente, nos move na busca de algo (ou alguém), muitas vezes nem se sabe bem do quê nem por quê.

Todo este frenesim parece nos levar na onda do consumismo teórico. Nesta procura, muitas vezes focamos nossas ações baseadas em teorias (não sei de quem) ou com bases nos estudos (também não sei de quem), a sociedade (acadêmica ou não) acaba moldando o ser humano e, então, transforma a vida em um círculo de ações repetitivas, sem mudar o modo de OLHAR e VER o que nos rodeia.

Não queremos dizer que teorias e estudos não são importantes - são sim! É, antes, a base para uma reflexão de nossas ações. Mas a questão é: o quanto ficamos presos a todas teorias e estudos, que em vez da reflexão destas com a nossa prática e vida cotidiana, engessamos nossas ações, o nosso OLHAR e o nosso VER? Por outras palavras, de que forma teorias, culturas e tradições, tempos e espaços cristalizam nosso pensamento e reflexão, paralisam sensibilidades, rotinizam nossa vida não permitindo VER mais além? Piovesan e Temporini (1995) referem,

As experiências de vida, ao lado do ensino formal, concorrem para a construção de conhecimentos, crenças, atitudes, valores, emoções e motivações, componentes importantes a condicionarem a percepção dos indivíduos acerca de fenômenos biológicos, psíquicos e socioambientais. Assim, a percepção constitui experiência sensorial que adquire significado à luz dessas influências (p. 318).

Esses modos de ser e estar na e para a sociedade estão hoje tão latentes que propor uma atividade onde o OLHAR e o VER é o foco, parece ser incoerente ou, pelo menos, inapropriado, retrógrado... E, para além disto, com um método tão comum: fotografar. Concordamos com Vinícius Aguiar, fotógrafo, que afirmou, "Fotografar é acima da arte de escrever imagens com luz. É eternizar momentos, sorrisos e lágrimas, maneira de expressar o que se vê ou sente" (2017, s/p). Sim, fotografar é eternizar um momento, é mostrar com imagens e luz as nossas emoções. Esse eternizar o momento por meio da lente de uma câmera tem a ver com a arte de VER.

Mas o que tem a ver esta arte com o processo de ensino e aprendizagem?

Esta 'arte' pode ser o início para uma atividade inovadora. Ao treinarmos nosso olhar tendemos a não ficar obtusos e focados apenas em resultados. Desta forma, podemos olhar (focar) nossos alunos como centro de nossas atividades. OLHAR, VER os seres humanos frente a frente e não abaixo de nós, já pode fazer uma grande diferença.

No entanto, cada pessoa tem a sua forma de OLHAR e VER as coisas que a cerca e trazer essa individualidade para o contexto educacional, para o desenvolvimento curricular e atribuir um significado pessoal a muitas das aprendizagens.

Como já dito, uma das maneiras de comunicar visualmente este olhar é através 
da fotografia que pode ser compartilhada pelos diversos canais de interação que há. É uma das formas a que o indivíduo recorre para selecionar, registar e "gravar" a sua leitura de uma determinada cena, situação ou acontecimento com seu modo de ver, comunicando visualmente a sua (intra) interação com o meio (social, ecológico, cultural, etc.) e com os espaços (naturais e construídos). Por isso,

\begin{abstract}
A fotografia é um recorte de tempo e espaço. Assim usualmente a definimos, mas tempo e espaço são variáveis que têm merecido níveis desiguais de atenção em nossas reflexões. Como todas as artes visuais, a fotografia suscita muitas questões sobre o espaço, porque diz respeito àquilo que é efetivamente visível: a imagem fotográfica é ela própria um espaço, uma superfície que oferece a representação de um outro espaço, aquele que faz parte do que chamamos de realidade. É, em geral, a relação entre esses espaços - a passagem de um ao outro - que nos esforçamos para compreender, pois duvidamos da simples coincidência entre eles (ENTLER, 2007, p. 29-30).
\end{abstract}

Essa leitura está, por si só, condicionada à sua história pessoal mediada pela realidade e pelo conhecimento de mundo que é portador. Um olhar que pode rejuvenescer sua forma de perceber e apreender o mundo. Mas, então, o que seria esta arte de ver?

\title{
2 I AFINAL O QUE É A ARTE DE VER?
}

A arte de VER e OLHAR envolve treino, mas esse treino amplia a percepção e, por meio desta, a descoberta de um universo sempre "amanhecente", um mundo com frescor e livre dos hábitos do cotidiano; exige uma nova forma de pensar e promove um encontro com o outro.

VER! Afinal o que significa ver? Além de ser um dos nossos sentidos, há muito mais ligado a este ato. Parece ser, num primeiro momento, algo mecânico, mas o que cada um vê está, de certa forma, embutido nos significados que foram gerados no transcorrer de sua existência. Cada um vê de acordo com as suas circunstâncias. Tal como Alves afirma,

\footnotetext{
Ver é muito complicado. Isso é estranho porque os olhos, de todos os órgãos dos sentidos, são os de mais fácil compreensão científica. A sua física é idêntica à física ótica de uma máquina fotográfica: o objeto do lado de fora aparece refletido do lado de dentro. Mas existe algo na visão que não pertence à física (2004)
}

Mas, então o que significa a arte de VER? Sabemos que arte, como atividade humana, está ligada a manifestações de ordem estética, elaborada por artistas a partir de sua percepção, emoções e ideias, e pode ter como objetivo estimular essas instâncias de consciência em um ou mais espectador. Paralelamente, o VER, por ser um verbo de ação, possui vários significados e entre estes destacamos: enxergar; contemplar; presenciar; possuir conhecimento acerca de; começar a perceber determinada coisa; 
concluir; prever; analisar minuciosamente; avaliar-se; maneira de pensar: a meu ver. (Dicio, 2017)

E é neste sentido, aliando a arte e a ação VER, que chegamos a um conceito sobre o que é a arte de VER, ou seja, é algo que envolve todos os nossos sentidos e está ligado às nossas percepções de compreensão sobre algo, é o olhar, o observar, o contemplar, o analisar, o relacionar as coisas materiais com os conhecimentos e experiências adquiridos e como resultado temos a estesia.

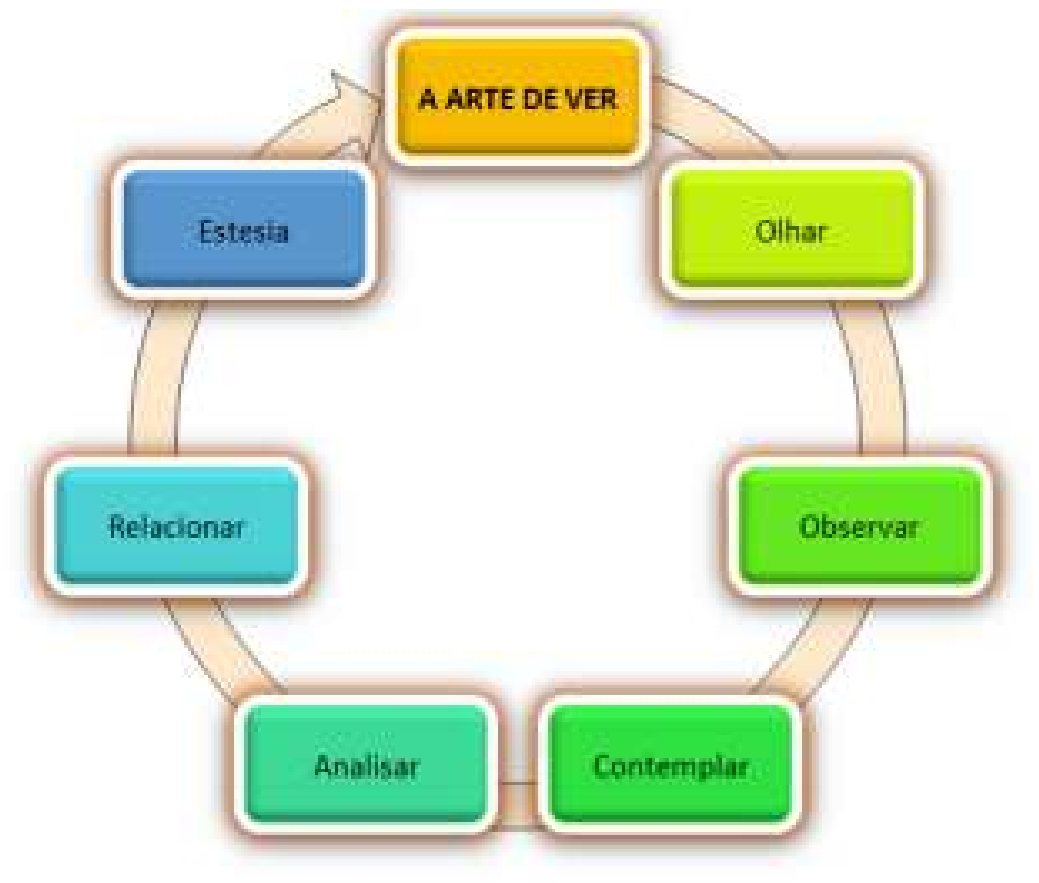

Figura 1 Conceito da Arte de VER. Elaborado pelas autoras

O conceito de experiência de Bondía (2002), além de contribuir com a elaboração deste conceito de arte de VER, também nos ajuda a pensar nesta atividade (VER) como um momento importante para colocarmos os nossos sentidos em um modo mais aflorado, onde o ouvir, sentir, pensar, refletir sobre os outros e nós mesmos toma uma posição de percepção e análise. O autor argumenta,

A experiência, a possibilidade de que algo nos aconteça ou nos toque, requer um gesto de interrupção, um gesto que é quase impossível nos tempos que correm: requer parar para pensar, parar para olhar, parar para escutar, pensar mais devagar, olhar mais devagar, e escutar mais devagar; parar para sentir, sentir mais devagar, demorar-se nos detalhes, suspender a opinião, suspender o juízo, suspender a vontade, suspender o automatismo da ação, cultivar a atenção e a delicadeza, abrir os olhos e os ouvidos, falar sobre o que nos acontece, aprender a lentidão, escutar aos outros, cultivar a arte do encontro, calar muito, ter paciência e dar-se tempo e espaço (BONDIA, 2002, p. 24).

Já Ansel Adams expõe que o ato de fotografar pode trazer uma noção de uma determinada época, das vivências de quem fez a fotografia. Pode ser até mesmo o reflexo da pessoa que registrou o momento, de suas memórias, argumenta "Não 
fazemos uma foto apenas com uma câmara; ao ato de fotografar, trazemos todos os livros que lemos, os filmes que que amamos" (2015).O experenciar de novas sensações usando todos os sentidos, como expõe Bondía (2002) e os argumentos sobre o ato de fotografar alegado por Ansel Adams (2015) são o grande enfoque para compreender que a arte de VER perpassa o simples OLHAR. A atividade de fotografar deixa de ser vista não só como uma das formas de guardar memórias de um determinado momento, mas também como uma forma de expor nossas emoções e afretamentos daquele momento.

\section{I FOTOGRAFAR: ENTRE O OLHAR, O VER E O ESTÉTICO}

Mas centremo-nos na arte de VER, já que este é um dos objetivos da atividade proposta aos estudantes (atividade que mais à frente é explanada), ou seja, que eles pudessem registrar em foto o que descobriram, o que "repararam" de novo, o que nunca perceberam no seu dia-a-dia, embora estivesse bem à frente de sua retina. Tal como a fotógrafa Alessandra Resende afirma "Fotografia, uma arte que nos envolve pela surpreendente forma de eternizar o que nosso olhar quer viver para sempre" (2018)Ernst Haas argumenta, "A câmara não faz diferença nenhuma. Todas elas gravam o que você está vendo. Mas você precisa VER" (2017), ou seja, a câmara grava o que você está vendo, gerando a fotografia, mas precisamos VER. E como "o ato de ver não é coisa natural. Precisa ser aprendido" (ALVES, 2004), foi com esta proposta que os estudantes foram desafiados. Pretendia-se o desenvolvimento de novas competências, novas formas de OLHAR e VER o que está ao seu redor. Através do registro por meio de fotos, isto é, através de uma linguagem que tem como elementos luz e sombra, os estudantes gravam imagens estáticas de momentos que não retornam mais e que estão relacionados com as emoções e experiências de cada pessoa naquele dado momento.

A câmera fotográfica, tendo o potencial de captar a realidade, com seus diferentes planos, cores e tonalidades, apresenta também algumas limitações. Uma das grandes limitações que o registo fotográfico apresenta é a ausência de "uma imagem sonora em movimento" que permitiria "auto explicar-se e induzir uma interpretação", pelo que,

\footnotetext{
[... ] a fotografia isolada, por mais rica em aspectos visuais e simbólicos, dificilmente consegue propor uma explicação ou uma interpretação. [...] tende sempre a ficar no limite da constatação, no caso de uma questão ou característica soco etnográfica. Vai ser o "olhar" do pesquisador que vai identificar nela a problemática sócio antropológica. Sem isso as fotografias parecem produzir apenas descrições rasas. (GODOLPHIM, 1995, p. 165).
}

E o autor acrescenta: "Fotografia, [...], pode ser considerada como uma obra aberta, passível de múltiplas interpretações”(1995, p. 170). 


\subsection{Os intervenientes e o processo}

Refletindo sobre conceitos da arte de ver de Rubem Alves (2004) e Alberto Caieiro (1993) e de educação estética de Duarte Jr. (2001), assim como um vídeo intitulado: "As cores das flores" (2010), foi proposto a um grupo de estudantes $(n=25)$ do Mestrado em Educação Pré-escolar e Ensino do $1^{\circ}$ Ciclo do Ensino Básico (201617) de uma universidade portuguesa o registo fotográfico de 10 situações/observações importantes. A atividade/tarefa transcorreu durante o período de férias escolares de Natal para que o ato de fotografar fosse prazeroso e de troca com seus pares, assim como também comunicasse um pouco do OLHAR e cultura do contexto em que estes sujeitos estão envolvidos.

Para clarificar o leque alargado de temáticas, foi facultada pela docente uma vasta lista de situações/objetos que, não sendo obrigatória, poderia orientar ou facultar ideias ou situações. Após o registo fotográfico, os estudantes deveriam partilhar com a turma, em aula, e fundamentar a lógica implícita no ato de ver e fotografar.

Sublinhamos que para esta tarefa: i) a qualidade da imagem/fotografia não era relevante; ii) as fotografias podiam ser tiradas através do aparelho celular, facilitando a acessibilidade e espontaneidade do ato de fotografar; iii) apenas foi verbalizado aos estudantes que deveriam tirar as fotografias sobre algum aspeto ou situação que lhes chamasse especial atenção.

Esta tarefa tornou-se em um estudo exploratório de caráter descritivo e interpretativo, cujo principal objetivo se centrava em relacionar experiências estéticas destes estudantes focalizadas entre o senso estético e o ato de ver.

O foco da análise das atividades realizadas pelos alunos - fotografias - foi especialmente sob um prisma estético, envolvendo o treino do olhar com uma perspectiva que vá ao encontro de lembranças e emoções suscitadas.

Este texto relata e analisa a atividade intitulada “Vamos fotografar?', apresentando apenas uma das análises possíveis, nomeadamente no que se refere às experiências estéticas proporcionadas por estas vivências, assim como refletir sobre a importância do olhar, do ver, da educação estética, da percepção e do senso estético na formação do ser humano.

\subsection{Um possível olhar sobre a tarefa}

Globalmente, as imagens selecionadas pelos estudantes foram permeadas de muitas memórias afetivas, ora envolvendo pessoas, ora envolvendo momentos e viagens, mas percebemos que as imagens estavam sempre relacionadas com seus familiares, o seu entorno, a sua casa, a sua cidade, a sua identidade cultural. Contudo, em pouquíssimas fotos, eles se incluíram no ambiente fotografado e não houve nenhuma self.

$\mathrm{O}$ ato de ver estava realmente focado no registro do que vemos muitas vezes e 
não percebemos, ou que nunca havíamos notado. Os dados sugerem um testemunho vivo de identidade conhecimento de siatravés da valorização de aspetos ou situações pessoais e quotidianas e a relação com o outro aponta para interações muito restritas/ circunscritas ou, talvez, não explicitadas. Quanto à visão de mundo mais abrangente verifica-se a descoberta de novos elementos e conhecimentos estéticos, históricos, contextuais, humanos, entre outros.

Concordando com as palavras de Neitzel e Carvalho "somos feitos daquilo que lemos, ouvimos e vivemos" (2016, p. 232), no nosso dia-a-dia emergem representações e percepções, representadas nas atividades que realizamos, mostrando parte da nossa identidade cultural. Nesta perspectiva, a análise das imagens e reflexões apresentada pelos estudantes permitiu a organização das categorias - Memória afetiva; Percepção estética; Ver além do olhar Imagens: significados, lembranças e; Educação estética que passaremos a analisar.

A memória é formada por lembranças positivas ou negativas. Conceituando: é um sistema que recebe, armazena, organiza, modifica e recupera a informação, e no ser humano ela dá e recebe através de experiências e estímulos. No âmbito da Psicologia é comum organizar a memória em três domínios: a memória sensorial que se manifesta pelos sentidos, a memória a curto prazo depósito temporário de informações com pouco significado e memória a longo prazo que é um processo construtivo e que se atualiza a cada nova recordação.

A memória afetiva está relacionada com a memória sensorial e a memória a longo prazo, ou seja, pode-se desenvolver a partir dos sentidos, mas só acontece se estiver interconectada a um momento afetivo. Quando se retoma memórias afetivas podemos provocar e guardar emoções e sentimentos tanto em sentido positivo como negativo. E neste sentido a fotografia é uma memória guardada. Entler afirma

\footnotetext{
Toda fotografia reconstrói seus lugares e personagens com base em códigos estabelecidos por alguma tradição. Ser fotografado é, portanto, ser apreendido por categorias estéticas e epistemológicas. Não obstante podermos lembrar que há ali uma história singular, a interpretação efetiva da imagem não nos conduz a alguém, mas a um papel: um aniversariante, uma noiva, um criminoso; ou uma família, um quadro de funcionários, uma multidão; ou um modelo de comportamento, de sensualidade, de poder, de subversão... A imagem parte de um lugar sempre situado no passado, mas aponta também na direção de uma virtualidade, isto é, constitui uma encenação quase atemporal dentro da qual um vasto universo de atores pode ser inserido (ENTLER, 2007, p. 30-31)
}

Entre as imagens apresentadas queremos destacar a seguintes imagens. 


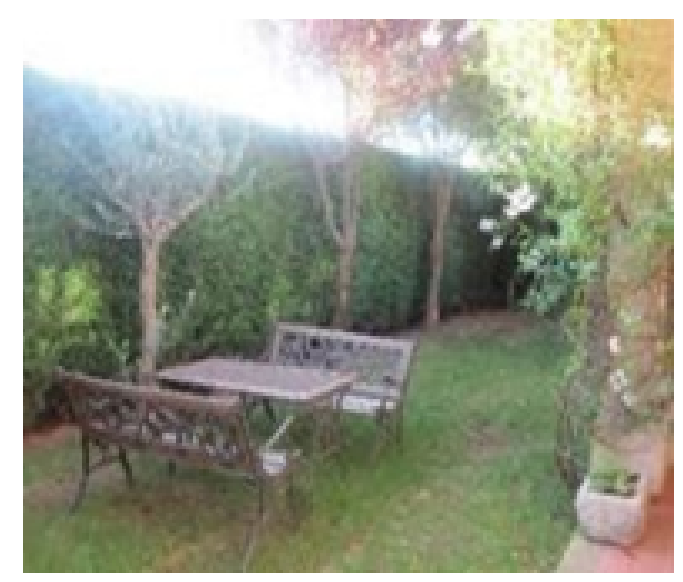

Figura 2. Banco do jardim de minha casa, memórias de família.

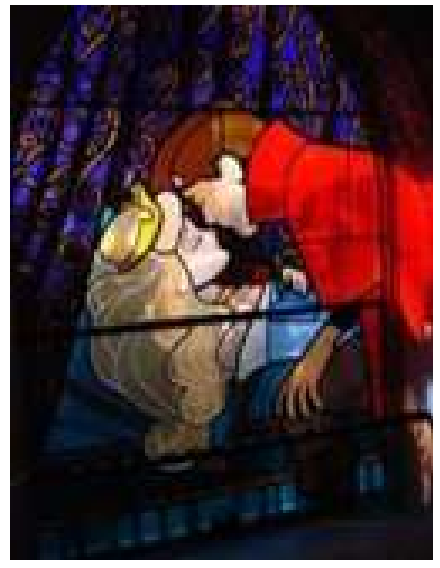

Figura 3. Uma viagem ao mundo infantil

O relato apresentado pela aluna, que apresentou a Figura 3, mostra todo o potencial que essa imagem produz em sua pessoa em todos os sentidos. Ela disse,

"Um local que me marcou muito, que me permitiu voltar ao meu mundo infantil que já vivi. Recordei muitas memórias dos meus desenhos animados preferidos e vivi toda a magia e meio envolvente. O contraste de cores e figuras que compõe estes vitrais transforma-me como se eu fosse uma personagem real, em que tudo que me envolve é tratado ao pormenor e nada é esquecido fazendo com que viva este mundo encantado".

Esta mesma fotografia e relato caracterizam uma outra categoria por nós analisada: percepção/experiência estética. Quando falamos de percepção estética não tem como não a relacionar com a experiência estética. A percepção tem a ver com toda parte sensorial e os processos que esta possa desencadear. De acordo com Reis,

A percepção estética não visa ao objeto segundo a sua finalidade prática ou utilitária, mas implica a abertura e entrega do sujeito a um mundo sensível que o convida não a decifrá-lo, mas a senti-lo (2011, p. 78).

Por sua vez, a experiência estética é a relação que o sujeito tem com o objeto, ou seja,

\footnotetext{
A experiência estética, em que pese as abstrações e raciocínios nela envolvidos e dela decorrentes, acontece primordialmente no corpo, colocando em funcionamento processos biológicos que têm a ver com isto que denominamos sentimento (DUARTE JR., 2001, p. 136).
}

Assim, e concordando com Duarte Junior (2001), a experiência estética acontece por meio da percepção estética, levando em conta a relação do sujeito com o objeto, livre de teorias, levando em conta somente as emoções suscitadas. Das fotografias e dos relatos dos estudantes, nesta categoria destacamos as seguintes imagens: 


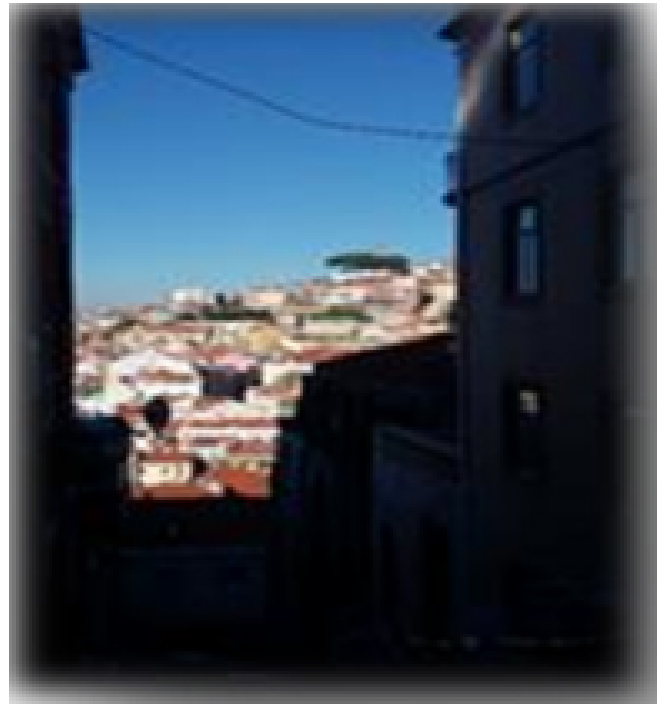

Figura 4. Lisboa, seu lado escuro, mas que há luz no fim do túnel

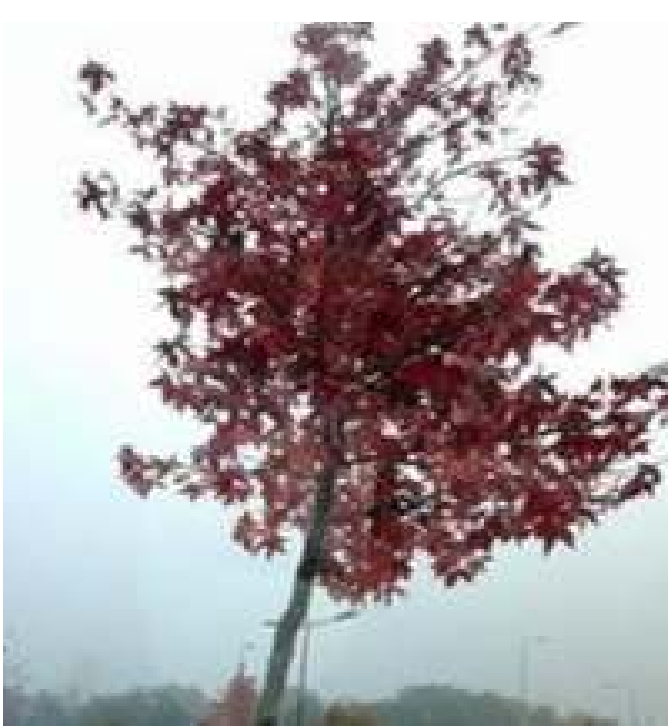

Figura 5. Árvores com diferentes cores versus a escola

Salientamos da Figura 5 o fundamento que o estudante acompanhou a esta fotografia, assumindo, não apenas a sua percepção estética, mas também a sua identidade profissional associada à experiência estética: o real da árvore com diferentes folhas, de diferentes tons de vermelho, pode ser relacionada com o real papel da escola, suas aprendizagens e obrigatoriedades, quando muitos professores pedem aos seus alunos para pintar a árvore de verde.

Ver, como já argumentamos, é um dos sentidos que muitos têm, mas ver além do olhar, ver além do que a íris do olhar revela, é muito complicado como aponta Rubem Alves (2004). Tal como o autor refere, envolve "partejar 'olhos vagabundos"'. É preciso se despir de todos os significados que o objeto em si representa, dando-lhes novos sentidos e significados.

A este respeito salientamos ainda que, entre todos os trabalhos apresentados, surgiram dois registros interessantes: (i) um estudante fotografou somente árvores e relacionou-as com as emoções que lidamos no dia-a-dia (Fig. 6 e 7) e (ii) outro registrou somente portas e relacionou-as com os obstáculos que encontramos em nossa vida (Fig. 8 e 9). 


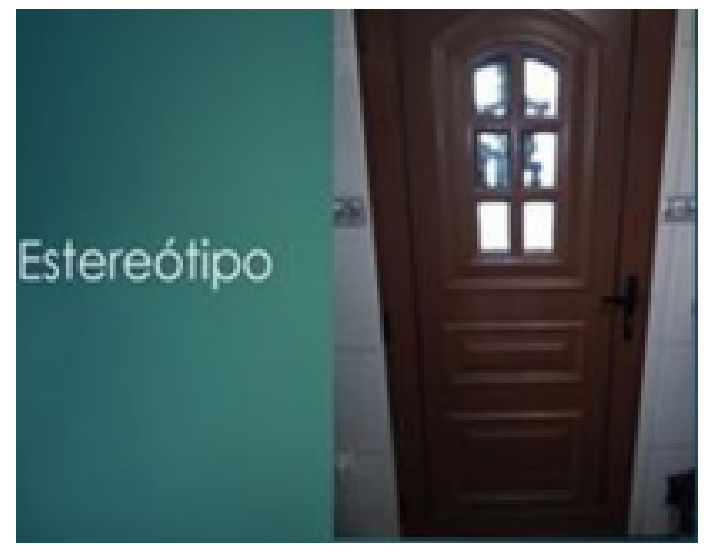

Figura 6. Estereótipos na sociedade

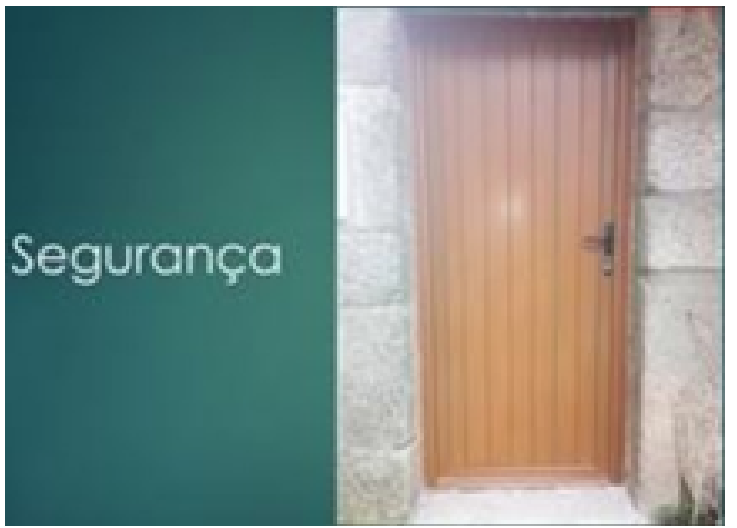

Figura 7. A segurança como pilar da vida

Por vezes, consideramos a existência de estereótipos na sociedade (Fig. 6), mas, tal como as portas, cada um é como cada qual, apresentando virtudes e fragilidades que o caracterizam. Importa que, de entre as suas virtudes, sintamos segurança porque todos nós necessitamos de segurança (Fig. 7), sendo esta característica daqueles são os pilares da nossa vida, nos apoiam e nos protegem.

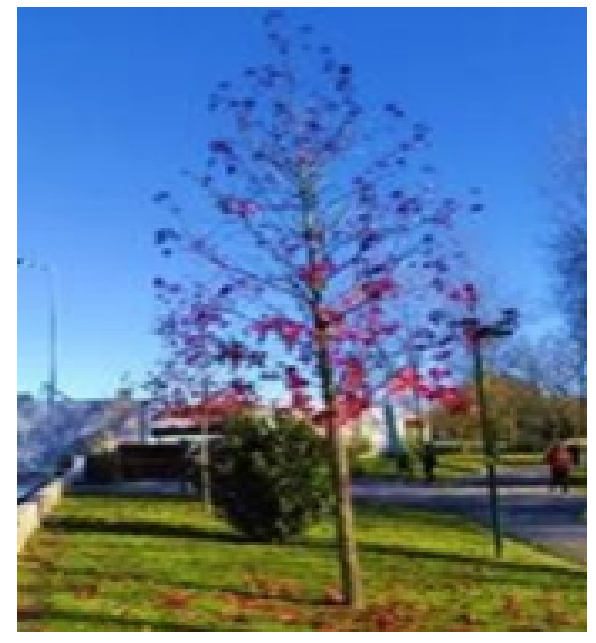

Figura 8. Quedas de folhas, mudança, desapego

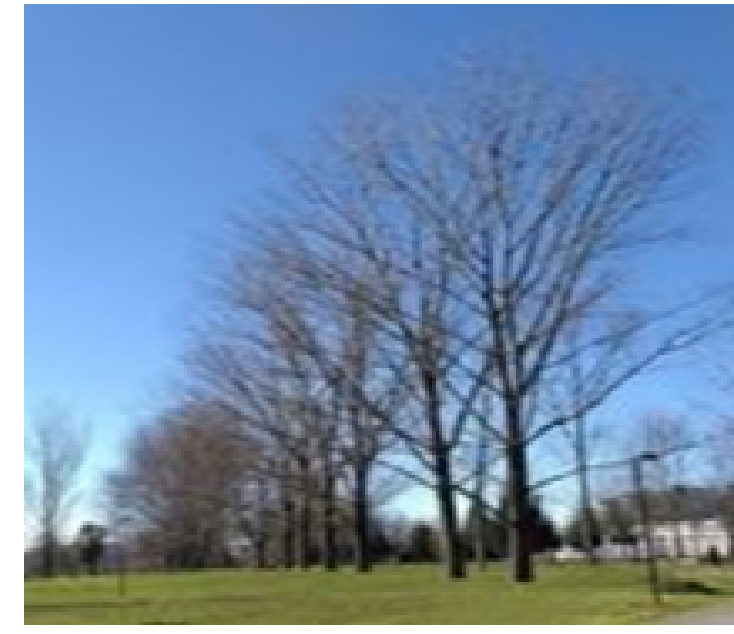

Figura 9. A árvore sem folhas, despidos. Sociedade destruidora - Perda de entes queridos

Queremos chamar a atenção para o afeto que as imagens retratadas podem representar em significados e lembranças. Sabemos que temos pouco controle ao sistema afetivo, visto que o afeto está relacionado a respostas e estímulos emocionais que variam conforma a intensidade. É como se sentíssemos de modo figurado "borboletas no estômago".

Em determinadas situações os conhecimentos, significados e crenças podem influenciar, estimular o sistema afetivo através de emoções, sentimentos, estados de humor e avaliações. Ao focar algo para registrar, muitos significados e lembranças evocam, a decisão do que é significativo para o indivíduo é baseado nas informações que são processadas pelo mesmo, de acordo com suas memórias. Sendo assim é uma experiência única. 
Muitas vezes os elementos fotográficos são ressaltados, em outras apenas o registro é importante. Podemos destacar as seguintes imagens:

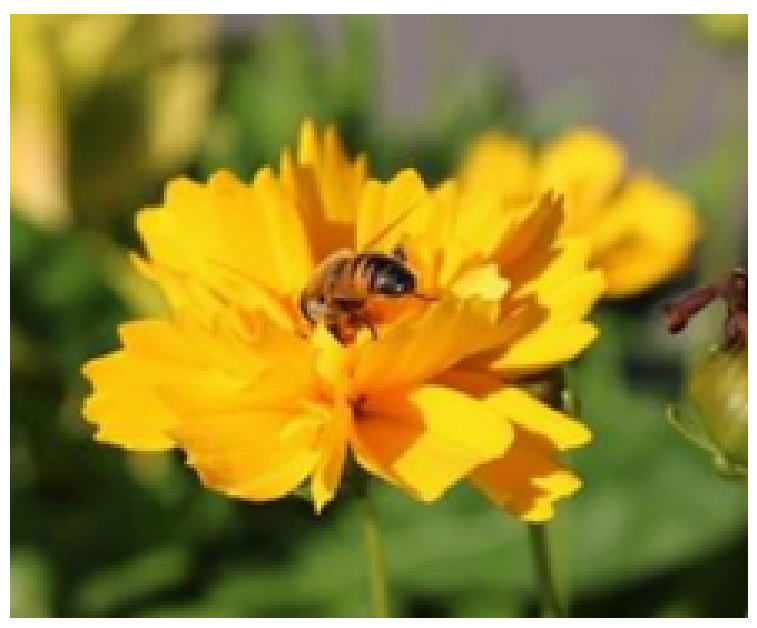

Figura 10. Flor e abelha tornam-se protagonistas

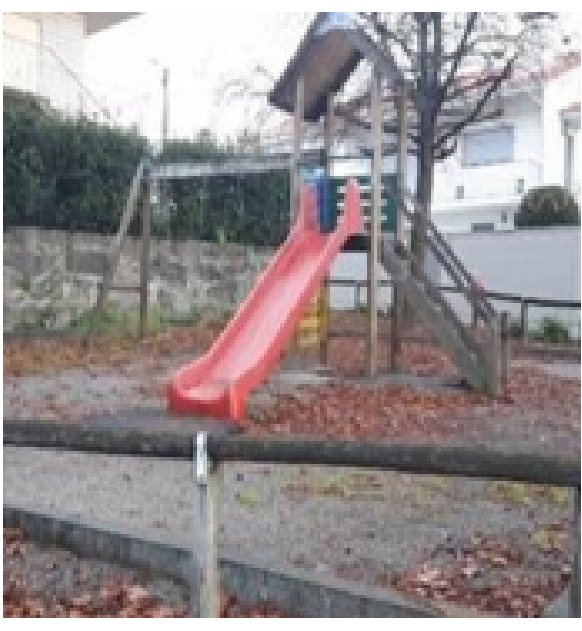

Figura 10. Parque infantil: brincar na infância

AFigura 10 lembra uma situação, um episódio, um acaso no "Jardim perto da minha casa". Esta fotografia, captada "com o meu irmão", mostra a beleza e grandiosidade da natureza. Foi um acaso, um "registo de um momento que vulgarmente nãoprestamos muita atenção. A flor e a abelha tornam-se protagonistas num belo exemplo da riqueza de observarmos os pormenores". Paralelamente, a imagem do parque infantil lembra e o ato de brincar na infância, representado nas palavras do autor,

"O Parque infantil junto da minha casa onde brinquei toda a minha infância;

O baloiço que dantes me parecia ficar tão longe do chão, mas que hoje está apenas a uma pequena distância dele.

Tirar esta fotografia, representou reviver emoções que tinha guardadas na minha memória, fez-me perceber e comparar a evolução do meu tamanho em relação às diversões que ocupavam os meus dias.

O tempo passa, as memórias permanecem.

"Em cada pequeno pormenor existe um mundo inteiro de emoções a descobrir..."”

Quando falamos de educação estética nos referimos aos estudos de João Francisco Duarte Jr. (2001). O autor argumentou que a educação estética é a educação do sentimento, a educação do sensível, e que a palavra estética está relacionada com a "[...] capacidade do ser humano de sentir a si próprio e ao mundo num todo integrado" (p. 13).

Estas sensações nos levam à estesia, que conforme o mesmo autor reflete, se relaciona a "[...] um dedicar-se ao desenvolvimento e refinamento de nossos sentidos, que nos colocam face a face com os estímulos do mundo" (p. 13). Educação estética ou a educação do sensível é, então, "desenvolver e refinar os sentidos" (p. 14).

Sendo assim a educação estética pode ampliar os referenciais e a visão de mundo dos indivíduos. Complementamos assim com Duarte Jr. (2001), 
[...]que nos largos domínios da educação estésica (ou educação do sensível) achase compreendida a educação estética, tomando-se aqui o termo "estética" com o sentido restrito que ele acabou adquirindo em nossos dias, ao dizer respeito mais especificamente à arte e à sua apreensão por um espectador, num dado contexto histórico e cultural (p. 184).

Entre as fotografias apresentadas distinguimos as seguintes:

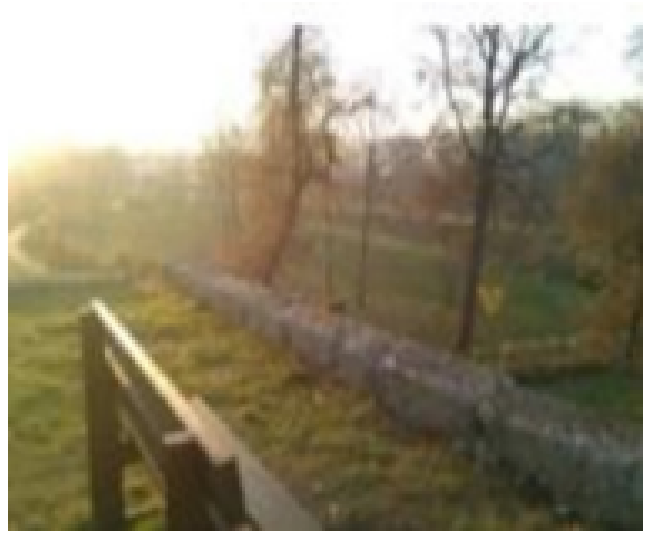

Figura 11. Banco: parar e pensar

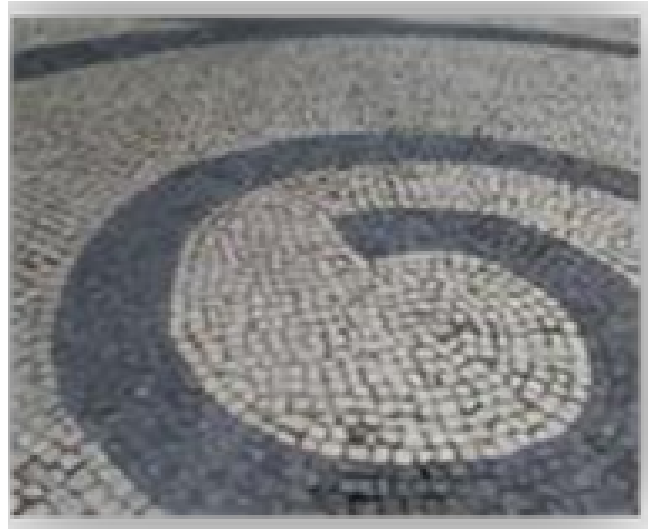

Figura 12. Calçada portuguesa, lembra de seu tempo de criança

O Banco (Fig. 11), integrado na natureza, real e cuidada, foi o elemento eleito porque o "merece, devido à sua vista. Há dias que precisamos de parar e pensar na beleza que nos rodeia para retomarmos à nossa paz interior, compreender o bem de todos os seres vivos".

\section{I UM NOVO OLHAR ...}

O meu olhar é nítido como um girassol.

Tenho o costume de andar pelas estradas olhando para a direita e para a esquerda, E de vez em quando olhando para trás...

E o que vejo a cada momento

É aquilo que nunca antes eu tinha visto

(CAEIRO, 1993, p. 24).

As palavras de Alberto Caeiro permitem-nos pensar sobre a importância do olhar que destinamos ao que está ao nosso redor, em todas as direções. Um olhar que se abre para o novo, a cada movimento, rejuvenescendo nossa forma de perceber o mundo. Esse treino do olhar amplia nossa percepção e, por meio dela, descobrimos um universo sempre "amanhecente", um mundo com frescor e livre dos hábitos do cotidiano.

O desconstruir conceitos, reorganizando estes, não é nada fácil, ainda mais quando se trata de algo óbvio: VER. Mas, ver além do que a retina nos apresenta, 
ver escutando, sentindo, refletindo, expressando é algo que tem que ser aprendido e apreendido.

Esta atividade realizada por estes estudantes permitiu não só o autoconhecimento dos envolvidos, como também permitiu que pudéssemos identificar as ideias e um pouco do contexto histórico de cada um diante do novo olhar que criaram ao perceber coisas que no dia-a-dia não notavam ou deixaram de notar. Novamente citamos Duarte Jr. (2001),

\begin{abstract}
O modo prático de ver o mundo orienta-se movido pelas questões "o que posso fazer com isto e que vantagens posso obter disto?", ao passo que o olhar estético não interroga, mas deixa fluir, deixa ocorrer o encontro entre uma sensibilidade e as formas que the configuram emoções, recordações e promessas de felicidade (p. 98).
\end{abstract}

Considera-se que esta atividade permitiu que os envolvidos pudessem cultivar este olhar estético, se tornando assim cidadãos atentos, críticos, autónomos e criativos localizados num contexto histórico e cultural.

Baseado nas análises das imagens, acredita-se que a fotografia, assim como a obra de arte, tem um significado para quem registra e outro para quem aprecia, pois a experiência é individual, a leitura das imagens pode até ser de senso comum para muitos, ou seja, interligando com fatos, tempos e lugares. Mas, é diante destas lembranças que podemos refletir sob uma perspectiva teórica e estético o OLHAR que vai além da retina humana.

Em suma, esta tarefa promoveu desafios, curiosidades e aprendizagens na arte de ver, i) identificando ideias e "pedaços de vida", ii) alertando para as relações intra e interpessoais tantas vezes atropelados pelo ritmo de vida ou menosprezados por fatores culturais, e iii) uma visão de mundo mais atenta e significativa enquanto cidadãos atentos, críticos, autónomos e criativos localizados num contexto histórico e cultural. Assim, podemos concluir que numa contemplação direcionada, a relação do sujeito com o objeto passará pela sua percepção comum e poderá levá-lo a uma percepção mais seletiva, a uma percepção estética, tornando possível o refinamento estético e cultural.

\title{
5 I AGRADECIMENTOS
}

Agradece-se a todos/as os/as estudantes a colaboração e autorização pela divulgação das suas fotografias.

\section{REFERÊNCIAS}

ADAMS, A. Diário Digital. Diário Digital [online], 15 Fevereiro 2015. Disponivel em: <http://www. diariodigital.com.br/dia-digital/nao-fazemos-uma-foto-apenas-com-uma-camera-ao-ato-de-fotografartrazem/126463/>. Acesso em: 02 Julho 2017. Por Luciano Muta. 
ALVES, R. Rubem Alves: A complicada arte de ver. Folha online Sinapse, 26 out. 2004. Disponivel em: <http://www1.folha.uol.com.br/folha/sinapse/ult1063u947.shtml>.

ALVES, RUBEM. A arte de Educar. Trilhando Autonomia. Disponivel em: <http://www.tautonomia. com/2015/07/arte-de-educar-rubem-alves.html>.

AS cores das flores. Intérpretes: Diego. [S.I.]: [s.n.]. 2010.

BONDIA, J. L. Notas sobre a experiência e o saber de experiência. Rev. Bras. Educ. [online], n. 19, p. 20-28, 2002. Disponivel em: <http://dx.doi.org/10.1590/S1413-24782002000100003>.

CAEIRO, A. Arquivo Pessoa. Arquivo Pessoa, 1993. Disponivel em: <http://arquivopessoa.net/ textos/1463>. Acesso em: 20 dezembro 2016. O Guardador de Rebanhos". In Poemas de Alberto Caeiro. Fernando Pessoa. (Nota explicativa e notas de João Gaspar Simões e Luiz de Montalvor.) Lisboa: Ática, 1946 (10 ed. 1993).

DICIO. Docionário Online de Português, 06 Julho 2017. Disponivel em: <https://www.dicio.com.br/ ver/>. Acesso em: 06 Julho 2017.

DUARTE JR., J. F. O sentido dos sentidos a educação (do) sensível. Curitiba: Criar, 2001. ENTLER, R. A fotografia e as representações do tempo. Revista Galáxia, São Paulo, dez 2007. 2946.

GODOLPHIM, N. A fotografia como recurso narrativo:problemas sobre apropriação da imagem enquanto mensagem antropológica. Horizontes Antropológicos, v. 02, n. 01, p. 161-185, jul/]set 1995. Disponivel em: <https://www.ufrgs.br/ppgas/ha/pdf/n2/HA-v1n2a13.pdf>. Acesso em: 01 Julho 2017.

NEITZEL, A. D. A.; CARVALHO, C. Estética e arte na formação do professor da educação básica. In: Mediação Cultural,formação de leitores \& educação estética. Curitiba: CRV, 2016. p. 231251.

PIOVESAN, A.; TEMPORINI, E. R. Pesquisa exploratória:procedimento metolológico para o estudo de fatores no campo da saúde pública. Saúde Pública [online], v. 29, n. 4, p. 318-325, 1995. Disponivel em: <http://www.scielo.br/pdf/rsp/v29n4/10>. Acesso em: 17 maio 2017.

REIS, A. C. A experiência estética sob um olhar fenomenológico. Arquivos Brasileiros de Psicologia, Rio de Janeiro, 63, n. 01, 2011. 75-86. Disponivel em: <http://pepsic.bvsalud.org/scielo. php?script=sci_arttext\&pid=S1809-52672011000100009>. Acesso em: 06 julho 2017.

RESENDE, A. pensador.com. Pensador, 2018. Disponivel em: <https://www.pensador.com/colecao/ alessandraresende/>. Acesso em: 10 set. 2018.

SALGADO, S. A fotografia mais do que nunca, tem um longo futuro. Revista Prosa Verso e Arte, 2017. Disponivel em: <http://www.revistaprosaversoearte.com/a-fotografia-mais-do-que-nunca-temum-longo-futuro-sebastiao-salgado/>.

VEIA, F. N. Fotografia na veia. As 27 melhores frases de fotografia, 2017. Disponivel em: <https:// fotografianaveia.com/as-27-melhores-frases-de-fotografia/>. Acesso em: 09 set. 2017. 


\section{O DIRETOR NO NOVO MODELO DE GESTÃO DA ESCOLA PÚBLICA PORTUGUESA E AS (DES) CONTINUIDADES DEMOCRÁTICAS: POLÍTICAS E PRÁTICAS}

\begin{abstract}
Maria Fernanda dos Santos Martins Universidade do Minho, Instituto de Educação Departamento Ciências Sociais da Educação/ Centro de Investigação em Educação
\end{abstract}

Braga, Portugal

Ana Paula Morais Macedo Universidade do Minho

Investigador da UICISA: E e professor na Escola de Enfermagem

Centro de Investigação em Educação.

Braga, Portugal

RESUMO: O presente trabalho insere-se numa investigação mais ampla sobre A governação e gestão das escolas públicas: o(a) diretor(a) em ação, sendo um dos seus eixos de análise a introdução da Nova Gestão Pública nas organizações escolares. Neste âmbito realizase um estudo de caso, que incide numa escola do ensino secundário, cuja principal técnica de recolha de dados são as entrevistas realizadas aos atores educativos pertencentes aos diferentes órgãos de gestão em torno da implementação do novo modelo de gestão. Os dados recolhidos permitem conhecer e problematizar a receção e recontextualização do referido modelo, sendo de destacar por um lado, a relação entre o diretor e o conselho geral e por outro, os sentidos de democracia e colegialidade na gestão.
PALAVRAS-CHAVE: gestão escolar, democracia, formação de professores

ASTRACT: This work is part of a broader investigation on The governance and management of the public schools: the director in action, as one of its axis of analysis the introduction of the New Public Management in the educational organizations. Within this scope, we have realized the case study of a school of the secondary education. We have realized interviews to the educational agents of different management bodies, on the implementation of the new management model. The collected data allow us to know and question the reception and recontextualization of that model, highlighting the relation between the director and the general council, and the meanings of the collegiality in management.

KEYWORDS: school management, democracy, training of teachers

\section{I INTRODUÇÂO}

De um ponto de vista sócio histórico, a gestão democrática das escolas em Portugal, que emerge com a Revolução dos Cravos, encontra-se associada, entre outros aspetos, à democraticidade e eleição, à colegialidade e à participação (LIMA, 2014). Assim, durante mais 
de 30 anos, assistiu-se à eleição dos membros órgãos diretivos das escolas públicas, em contraste com o regime de nomeação anterior, classificado por autoritário.

Para além deste caráter democrático de que se reveste a eleição, também se destaca outra característica da gestão democrática, a existência de órgãos colegiais, com representantes eleitos, quer no caso de órgãos de gestão de topo (numa fase inicial os conselhos diretivos e, mais recentemente, também o conselho geral), quer em órgãos de gestão pedagógica intermédia (LIMA, 2014). Nesta lógica, apesar da importância atribuída à colegialidade, torna-se fundamental ter em linha de conta não só o processo de eleição, mas também os poderes que detêm os tais órgãos colegiais, como é o caso de alguns, que podem escolher democraticamente os seus líderes. Era esta a situação do conselho pedagógico, dos departamentos curriculares, entre outros. Neste quadro, a figura do presidente do conselho diretivo e, mais tarde, do conselho executivo, repartia a sua liderança com outros elementos do órgão, bem como com os demais órgãos de governação da escola.

A partir do final da década de noventa assiste-se, na realidade portuguesa, à introdução de perspetivas da Nova Gestão Pública no domínio da educação, nomeadamente na sua gestão. Do ponto de vista normativo-legal, não obstante as alterações ocorridas a partir do Decreto-Lei n ${ }^{\circ} 115-A / 98$, de 4 de maio, será o DecretoLei $n^{\circ} 75 / 2008$, de 22 de abril, que altera de modo mais significativo este cenário de gestão menos democrática.

No presente trabalho, para além da análise a algumas mudanças introduzidas, do ponto de vista formal, na gestão das escolas portuguesas, procurou-se a partir de um estudo de caso trazer dados que nos permitissem conhecer e problematizar a receção do referido modelo e as respetivas mudanças (não)realizadas em termos de gestão da escola pública portuguesa.

\section{I NOVO MODELO DE GESTÃO DAS ESCOLAS PÚBLICAS PORTUGUESAS}

O Decreto-Lei $n^{\circ} 75 / 2008$, de 22 de abril tem sido objeto de múltiplas investigações com um pressuposto comum que assenta, por um lado, no carácter recentralizador do poder político e da administração escolar e, por outro, pela emergência da liderança unipessoal, concentrando sobresivários poderesecompetências. Importacontextualizar que esta última alteração surge em decorrência de um processo normativo lento e gradual de concentração de poderes no órgão de gestão, ainda que em períodos e em modelos anteriores o órgão de gestão apresentasse uma configuração colegial (cf. MARTINS, 2009; 2011). Também importa clarificar que esta alteração ao modelo de gestão ocorre no contexto de implementação de um outro conjunto de medidas em matéria de administração escolar, destacando-se: a constituição de agrupamentos de escolas, a adesão a modalidades de autonomia técnica e instrumental, entre outras.

Dentro deste cenário surgem interpretações acerca da figura do diretor que se 
inscrevem num movimento de desconcentração algo radicalizado, capaz de assegurar o tradicional predomínio do centro sobre as periferias e de o dotar de maior eficácia em termos de controlo, transformando o seu cargo no "rosto" do poder central junto da escola.

Note-se que a expressão desta nova lógica de regulação das escolas era previsível se também tivermos em ponderação que desde a década de 1980 já existiam sinais de mudanças - práticas de gestão democrática débeis, consubstanciadas, entre outros aspetos num decréscimo substantivo na apresentação de listas concorrentes ao conselho diretivo (Lima, 2011). Assim, assiste-se à imposição de um novo modelo de governação que, para além da concentração de poderes no órgão de gestão, acaba por atribuir significativos poderes e competências a um único sujeito, "dessa forma alongando e verticalizando o respetivo organigrama e reforçando as prerrogativas de uma liderança formalmente unipessoal" (Lima, 2011, p. 47). De modo específico,

\footnotetext{
"(...) o director concentra sobre si vinte e cinco competências, preside ao conselho pedagógico por inerência, tudo parecendo girar em seu torno, fragilizando as estruturas colegiais existentes e pondo fim à quase totalidade dos processos de escolha democrática nas escolas. (...). O director passa, agora, a nomear e a demitir livremente o subdirector, os assessores, os coordenadores de departamentos, os coordenadores dos estabelecimentos agrupados, numa lógica gestionária de um perfil, um projeto, uma equipa de gestão, remetendo para algo semelhante ao princípio da 'unidade de comando', proposto no início do seculo XX por Henry Ford (1984)" (ídem, p.58).
}

A centralidade remetida ao diretor, responsável por cada escola ou agrupamento pode ser um factor de erosão da gestão democrática e, consequentemente, de fragmentação das práticas de colegialidade dos profissionais, que cada vez se vão tornando mais formais e uniformes. Para além deste plano de funcionamento da organização regista-se, no que diz respeito à supervisão da execução das políticas educativas centrais, a existência de uma ambiguidade latente na figura do diretor, a sua subordinação ao poder central (LIMA, 2011, p. 57).

Neste sentido, foram criadas condições, do ponto de vista formal, para uma alteração profunda nas relações de poder no interior da escola, na medida em que se procura que "em cada escola exista um rosto, um primeiro responsável", no sentido de "reforçar a liderança da escola e de conferir maior eficácia, mas também mais responsabilidade ao director (Decreto-Lei $n^{\circ}$ 75/2008, 22 de abril). No passado, nomeadamente no âmbito da gestão democrática, tal como já tivemos oportunidade de fazer alusão, as relações de poder caracterizavam-se por tempos e espaços em que as decisões, ainda que apenas em matérias de gestão-execução, pautavam-se pela possibilidade de manifestação de interesses diversificados, pela liberdade de expressão e abertas à participação, por lógicas colegiais, específicamente no caso dos profesores (LIMA, 2007).

Face ao exposto, parece existir um leque de possibilidades de lideranças 
emergentes, assumidas pelos atores ora como mais individuais, ora como mais estratégicas ou, ainda, como mais democráticas. Constitui-se um desafio questionarmos se no plano da ação se reproduz o perfil do líder unipessoal, assacando a si os poderes e competências previstos na legislação ou se os atores escolares resistem a esta figura, demonstrando capacidade de produzirem orientações próprias no sentido da democratização da gestão da escola, na qual há uma partilha de poderes e competências, ainda a que num registo não formal e informal. Por outro lado, no modelo em causa, com os argumentos de "reforçar a participação, de "abertura da escola ao exterior" e de consagrar "não apenas os direitos de participação dos agentes do processo educativos", instituiu-se um "orgão de direção estratégia", o conselho geral (DECRETO-LEI n 75/2008, de 22 de abril). Contudo, não podemos deixar de questionar esta função estratégica do conselho geral no quadro de um modelo de administração do sistema educativo que se caracteriza como centralizado desconcentrado (Formosinho, 1986), bem como a inexistência de autonomia para as escolas públicas portuguesas.

No plano interno da escola, importa salientar que a este órgão "confia-se a capacidade de eleger e distituir o diretcor, que por conseguinte lhe tem de prestar contas" (ibidem). Neste sentido, questionamos a receção pelos atores educativos da nova forma de eleição do diretor e, ainda, procuramos conhecer e problematizar o lugar que ocupa cada uma destas figuras, o conselho geral e o diretor, no interior da escola. Interrogamos se não haverá uma tendência para uma desvalorização do órgão colegial e protagonismo do diretor. Concretamente, podemos interrogar que questões pode o conselho geral discutir no âmbito da definição da política da escola/ agrupamento, se esta não é detentora de autonomia e, ainda, face à possibilidade de o diretor influenciar o funcionamento deste órgão, uma vez que possui um leque bastante amplo de competências no interior da escola.

De modo a refletirmos sobre as questões anteriormente mencionadas, mobilizamos dados de um estudo de caso, de uma escola do ensino secundário, situada no Norte do país, apresentados nos pontos que se seguem. Este estudo insere-se numa investigação mais ampla desenvolvida por um grupo de investigadores do Centro de Investigação em Educação, Instituto de Educação, Universidade do Minho, sobre A governação e gestão das escolas públicas: o(a) diretor(a) em ação, sendo um dos seus eixos de análise a introdução da Nova Gestão Pública (CLARKE \& NEWMAN, 1997; BALL, 2005), nomeadamente no contexto das organizações escolares.

\section{I NOTAS METODOLÓGICAS}

A metodologia de suporte ao estudo situa-se num paradigma de investigação naturalista, o método é o estudo de caso (YIN, 2005). O estudo de caso incidiu num estabelecimento do ensino secundário criado no ano de 1979, situado no norte de 
Portugal. Trata-se de uma Escola sem contrato de autonomia e tem uma oferta formativa de $3^{\circ}$ Ciclo ( $7^{\circ}$ ano; $8^{\circ}$ ano; $9^{\circ}$ ano), com uma vertente de Cursos CientíficoHumanísticos. A população da escola constitui-se em 180 professores, 55 funcionários e 1 psicóloga que têm por função apoiar 1498 alunos, repartidos por 8 turmas do $3^{\circ}$ ciclo do ensino básico diurno, 51 turmas do ensino secundário diurno (22 das quais de cursos profissionais) e 21 turmas do ensino noturno (6 dos cursos científicohumanísticos, 8 dos cursos tecnológicos e 7 dos Cursos de Educação e Formação de Adultos) (Regulamento Interno da Escola Secundária, 2013).

No âmbito deste estudo recorreu-se, de modo predominante, a duas técnicas de recolha da informação: o inquérito por entrevista a diferentes atores escolares, bem como à análise de documentos de cariz oficial (Regulamento Interno, Plano anual de Atividades, Projeto Educativo, entre outros), como forma de se poder captar as orientações normativas produzidas no contexto escolar. As entrevistas definiram-se como semi-estruturadas (AMADO \& FERREIRA, 2014), intencionalmente realizadas a diferentes atores educativos da escola em causa. As questões foram sistematizadas num guião comum e pré-concebido pela equipa mais alargada da investigação, sendo o mesmo utilizado com flexibilidade e adaptado ao perfil de cada escola/agrupamento e entrevistado. Assim, obtivemos um número total de doze entrevistados, que descrevemos no quadro a seguir (a entrevista ao ex-presidente da associação de pais e encarregados de educação justificou-se na medida em que o atual presidente havia tomado posse há muito pouco tempo e no caso do ex-presidente da associação de estudantes porque no momento da realização da entrevista estava ainda a decorrer as eleições para esta estrutura). A realização das entrevistas ocorreu no final do ano letivo de 2014/2015 e todas as entrevistas foram efetuadas nas instalações da escola, nomeadamente em gabinetes pertencentes à direção. As referidas entrevistas, cuja duração média se situou entre quarenta minutos e duas horas, foram registadas sob a forma de áudio, após a obtenção das autorizações dos respetivos entrevistados. Os participantes ficaram cientes de que os dados obtidos poderiam ser divulgados junto da comunidade académica, respeitando o carácter confidencial das identidades.

\begin{tabular}{|c|c|c|c|c|}
\hline $\begin{array}{l}\text { Entrevistado na } \\
\text { qualidade de }\end{array}$ & Sexo & Idade & Área Disciplinar & Tempo na escola \\
\hline $\begin{array}{c}\text { Representante da } \\
\text { Autarquia }\end{array}$ & Masculino & 58 & ---------------- & --------------------------' \\
\hline $\begin{array}{c}\text { Ex- Presidente da } \\
\text { Associação de Pais } \\
\text { e Encarregados de } \\
\text { Educação }\end{array}$ & Masculino & 48 & 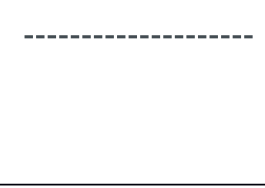 & 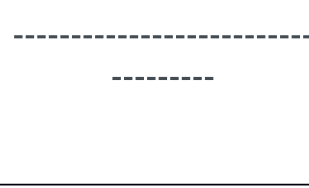 \\
\hline $\begin{array}{c}\text { Presidente da } \\
\text { Associação de Pais } \\
\text { e Encarregados de } \\
\text { Educação }\end{array}$ & Masculino & 42 & --------------------- & $\begin{array}{c}1^{\circ} \text { ano de mandato } \\
\text { Educanda } 8^{\circ} \text { ano }\end{array}$ \\
\hline
\end{tabular}




\begin{tabular}{|c|c|c|c|c|}
\hline $\begin{array}{l}\text { Representante dos } \\
\text { Professores no } \\
\text { Conselho Geral }\end{array}$ & Masculino & 57 & Humanidades & 25 anos \\
\hline $\begin{array}{l}\text { Representante dos } \\
\text { Funcionários no } \\
\text { Conselho Geral }\end{array}$ & Masculino & 47 & --------------------- & 18 anos \\
\hline $\begin{array}{l}\text { Professora mais } \\
\text { velha }\end{array}$ & Feminino & 60 & Matemática & 7 anos \\
\hline $\begin{array}{c}\text { Professora mais } \\
\text { novo }\end{array}$ & Masculino & 48 & $\begin{array}{l}\text { Engenheiro } \\
\text { Mecânico }\end{array}$ & 7 anos \\
\hline $\begin{array}{l}\text { Coordenadora do } \\
\text { Departamento }\end{array}$ & Feminino & 50 & Humanidades & 23 anos \\
\hline $\begin{array}{l}\text { Coordenador do } \\
\text { Departamento }\end{array}$ & Masculino & 57 & Geologia & 23 anos \\
\hline $\begin{array}{l}\text { Ex-Presidente da } \\
\text { Associação de } \\
\text { Estudantes }\end{array}$ & Masculino & 21 & -----------------' & 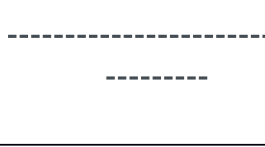 \\
\hline $\begin{array}{l}\text { Presidente do } \\
\text { Conselho Geral }\end{array}$ & Masculino & 52 & Informática & 25 anos \\
\hline Diretor & Masculino & 59 & $\begin{array}{c}\text { Engenharia } \\
\text { de Sistemas } \\
\text { Informáticos } \\
\text { Especialização } \\
\text { Administração } \\
\text { Escolar }\end{array}$ & $\begin{array}{c}32 \text { anos } \\
\text { 1985- inicia } \\
\text { funções na } \\
\text { gestão }\end{array}$ \\
\hline
\end{tabular}

Quadro 1: Dados de caracterização dos entrevistados

A pluralidade e riqueza dos discursos dos atores permitiu-nos conhecer e problematizar a receção do novo modelo de gestão e as tendências no plano da ação da escola em estudo. Neste quadro, destacamos a ênfase a aspetos críticos do modelo em vigor, mas destacamos, igualmente, a ação dos atores no sentido da manutenção de modos de funcionamento vigentes no quadro do modelo de gestão anterior, tidos como mais democráticos, colegiais e participativos.

\section{I CONSELHO GERAL: FORMA E SUBSTÂNCIA EM CONFRONTO}

Face aos discursos dos atores da escola em estudo parece que o principal atributo do conselho geral é a possibilidade de assegurar a participação da comunidade na escola. Portanto, o carácter democrático deste órgão advém, na ótica dos participantes, da garantia da representatividade de diferentes categorias de atores no referido órgão. Regista-se, assim, que o conselho geral "é um órgão tipicamente democrático, tem 
os diferentes corpos da comunidade representados" (coordenador de departamento), "que integra elementos da comunidade, e isso é muito importante" (diretor), que sendo "um órgão onde estão representados, os professores, os alunos, os pais, a autarquia, outras entidades, podemos então ter opiniões diferentes" (presidente do conselho geral) e, ainda, tratar-se de um órgão possuidor de "uma grande virtude, é verdade, tenta fazer com que a comunidade participe na vida da escola"(representante da autarquia no conselho geral).

Porém, esta potencialidade do órgão parece perder importância quando confrontada com as possibilidades reais de definição da política da escola, não coincidindo a forma com a substância. Desde logo, porque, de forma praticamente consensual entre os atores entrevistados, este órgão é desvalorizado pelo ministério da educação, como podemos confirmar nestas palavras:

"(...) se alguém desse ouvidos ao conselho geral, quando eu digo alguém, é mais acima (...), se o conselho geral tomasse uma posição e depois o ministério, mas afinal cada um pode tomar as decisões que entender, porque as ordem vêm de cima" (professora mais antiga).

Neste cenário, o diretor chega mesmo a interrogar: "O que adianta termos uma gestão democrática se não somos ouvidos pelo ministério?" (diretor) e, nesse mesmo sentido, "o que interessa o modelo de gestão, se não há autonomia, o que interessa?" (presidente do conselho geral).

No plano interno da escola, a relação entre diretor e presidente do conselho geral define-se para alguns como "cordial, com diálogo do ponto de vista institucional "(coordenador de departamento) e o conselho geral pode ser considerado como um "órgão colaborativo, de opinião" (presidente do conselho geral). Também a relação é considerada de muito próxima para um dos entrevistados:

"(...) o diretor e o conselho geral sempre tiveram uma relação de cooperação, na altura de tomada de posse, por exemplo, veio o diretor e veio o presidente do conselho geral, (...) há uma relação de proximidade com o diretor" (presidente da associação de estudantes).

Não obstante a boa relação entre os dois órgãos, é evidenciada uma tendência de sobreposição do diretor face ao conselho geral e, por sua vez, uma subordinação deste último face ao diretor, na medida em que: i) "a agenda da reunião é conversada entre o presidente do conselho geral e o diretor e também porque o diretor informa o presidente do conselho geral das suas decisões" (presidente do conselho geral); ii) por vezes é a própria direção a incitar o surgimento das referidas listas (cf, entrevista do diretor). Neste cenário, não será de admirar que quando interrogados os atores sobre onde se localiza o poder no interior da escola, uma parte significativa tenha referido que é no órgão de gestão, ou se seja no diretor, até porque

"(...) é o diretor que tem de decidir e é o diretor quem se responsabiliza pelas suas 
Apesar de internamente o conselho geral apresentar um papel diminuto, devido em grande parte ao protagonismo dado pela lei ao diretor, para alguns atores parece que o poder do conselho geral aumenta quando se trata de reivindicar, fora dos muros da escola, maior autonomia para esta organização:

"(...) com o conselho geral a comunidade passou a ter a visão de como a escola é limitada, que não tem autonomia. É bom que tenham essa visão porque sensibilizando a comunidade eles podem em diferentes instâncias participarem e dizerem que a escola tem de ter uma maior margem de autonomia" (diretor).

\section{I MENOS DEMOCRACIA NA ESCOLA: O CASO DA ELEIÇÃO DO DIRETOR}

No quadro do novo modelo, a eleição realizada em sede de conselho geral é tida pelos atores, no que ao critério da democraticidade diz respeito, como uma democracia restrita, com todas as desvantagens da democracia representativa. Apontam como alternativa uma eleição de base mais alargada, tal como afirma o representante da autarquia no conselho geral: "diretor escolhido por este órgão [conselho geral] está a ser menos democrático do que se fosse escolhido pelo sufrágio eleitoral". Outros apontam a diminuição da democracia com o atual processo de eleição, uma vez que se trata de uma eleição indireta; nas suas palavras: "quer dizer, não é tão democrático, mas indiretamente é, quero dizer não é tão direto, é um processo democrático diferente, mas não deixa de ser, claro" (representante dos professores no conselho geral). No mesmo sentido, o professor mais antigo da escola também considera este processo pouco democrático, e estabelece uma comparação entre as eleições para o governo de um país e a eleição para diretor de escola, afirmando que:

“(...) uma das falhas principais é mesmo essa, a de nós não elegermos quem nos dirige, porque elegemos muito indiretamente, elege-se o conselho geral e este elege o diretor. (...) posso não estar muito dentro do que é uma direção de uma escola, etc., mas eu também não estou muito por dentro do que é um governo e vou votar para o governo; portanto, aqui eu também acho que podia votar diretamente para o diretor da escola".

No mesmo sentido aponta o representante da autarquia no conselho geral, nas suas palavras:

"(...) porque na realidade ao ser, por exemplo, o diretor, escolhido por este órgão (conselho geral), está a ser menos democrático do que se fosse escolhido pelo sufrágio universal". 
Repare-se que, no modelo anterior, previsto no Decreto-Lei $n^{\circ} 115-A / 98$, de 4 de maio, a eleição do diretor/presidente do conselho executivo obedecia a uma participação alargada da comunidade educativa e, ainda, a eleições diretas, para certas categorias de atores, como é o caso dos professores. Como podemos ler no referido decreto:

\footnotetext{
"Os membros do conselho executivo ou o director são eleitos em assembleia eleitoral, a constituir para o efeito, integrada pela totalidade do pessoal docente e não docente em exercício efectivo de funções na escola, por representantes dos alunos no ensino secundário, bem como por representantes dos pais e encarregados de educação. 2 - A forma de designação dos representantes dos alunos e dos pais e encarregados de educação será fixada no regulamento da escola, salvaguardando: a) No ensino básico, o direito à participação dos pais e encarregados de educação em número não superior ao número de turmas em funcionamento; b) No ensino secundário, o direito à participação de um aluno por turma e de dois pais ou encarregados de educação, por cada ano de escolaridade" (artigo 19, alínea a e b).
}

A este respeito, o coordenador de departamento considera que o processo de eleições diretas contribuiria para um maior conhecimento, por parte dos eleitores, relativamente aos planos de intervenção do diretor:

\footnotetext{
"Temos um modelo já muito pouco democrático no sentido do processo, (...) por isso os processos eram mais participados, hoje cada vez menos, eu atrever-me-ia a dizer que 99,9\% das pessoas não sabem o que é que o atual diretor desta escola colocou no seu programa".
}

Dos discursos apresentados, as críticas ao processo de eleição prendem-se com a passagem de uma eleição que se enquadrava numa democracia de tipo mais participativo para o registo de uma democracia de tipo mais representativo. Nesse sentido, o atual modelo parece estar a contribuir para aumentar o divórcio, o fosso, entre os atores educativos e a gestão da escola, com sérias implicações na participação, transformando-se esta num ritual formalizado: "Eu acho que temos menos participação, no sentido em que as pessoas, hoje, não discutem as coisas, embora cumpram a obrigação de dar uma opinião formal!" (coordenador do departamento).

\section{I LIDERANÇA DO DIRETOR: PASSAGEM SERENA DA COLEGIALIDADE PARA UNIPESSOALIDADE}

A concentração de poderes no diretor consiste noutra mudança atribuída à publicação do Decreto-Lei $n^{\circ} 75 / 2008$, como referimos anteriormente. Contudo, os 
atores entrevistados fazem uma dissociação entre a lei e as práticas naquela escola em concreto. Da análise dos discursos recolhidos, constatamos que os atores entrevistados claramente identificam, do ponto de vista normativo-legal, a concentração de poderes na figura do diretor de escola, como podemos confirmar nos seguintes extratos: "Na lei, onde se decide é ali mesmo no gabinete do diretor" (professora mais antiga).

Esta ideia é também reforçada por um dos representantes dos professores no conselho geral e por um coordenador de departamento ao compararem o atual modelo com o anterior, nomeadamente, no que diz respeito à existência de assessorias e ao funcionamento colegial, respetivamente:

\begin{abstract}
"Eu, às vezes, questiono-me sobre isto, tendo em conta que o poder está muito centrado no diretor, enquanto no anterior modelo havia um conselho e acho que havia uma delegação de poderes pelas várias assessorias, agora não, está tudo muito concentrado no diretor. (...). Eu acho que o órgão de decisão máxima acaba por ser a direção" (professor do conselho geral).

"(...) se lermos a legislação de uma forma muito restritiva nem tudo pode ser delegado, o que é que acontece vamos concentrar tudo no diretor, criando uma situação terrível. (...) porque nem tudo é delegável e há muita coisa que para uma organização viva, não pode parar num organismo vivo, e por isso é mau que esteja tão concentrado, funcionava e sempre funcionamos muito bem com os órgãos colegiais, eu gostei muito do modelo com o conselho diretivo" (coordenador de departamento).
\end{abstract}

De entre os poderes concentrados na figura do diretor, há referências concretas à nomeação dos coordenadores de departamento, ainda que os entrevistados se mostrem em desacordo com a mesma:

\footnotetext{
"Claro que o diretor tem o poder muito centrado nele inclusive em determinadas situações permite que ele designe ou nomeie um representante para certas estruturas da escola. Por exemplo, o de coordenador de departamento e de outras estruturas. É claro que isso já não é muito democrático, acho que dentro de um departamento o seu coordenador deveria ser escolhido pelos membros desse departamento" (professor mais novo).
}

Esta preocupação dos professores, com a nomeação dos coordenadores de departamento, justifica-se porque são sobretudo estes que "correm o risco de ficar reféns do director, sem órgãos próprios e autónomos, sem intermediação e tipo colegial, no quadro de uma estrutura interna extremamente centralizada na figura do director" (LIMA, 2011, p. 58).

Porém, ao nível do domínio da ação organizacional da escola investigada parece existir uma desvinculação da lei, na medida em que os atores referem que não houve grandes mudanças, justamente porque a pessoa que está a ocupar o cargo de diretor é a mesma que ocupava o cargo de presidente do conselho executivo, mantendo-se, na perspetiva dos entrevistados, uma liderança de tipo democrática, como a que existia anteriormente. A este propósito, um dos entrevistados refere que o diretor procura 
"ser o mais democrático possível", nomeadamente pela razão de solicitar a opinião de outros atores:

"Não, não mudou, só mesmo esses pormenores, não é? O não podermos ser verdadeiramente democráticos ..., porque de facto ele tenta e aqui há esta tentativa de mesmo assim ser o mais democrático possível (...)" (professora mais antiga).

$\mathrm{Na}$ escola em questão, segundo os entrevistados "ele (diretor) gosta mais da gestão democrática e faz isso" (presidente do conselho geral) ou, então,

“(...) a práxis do diretor é que pode determinar esta distribuição de poder que eu acho que é vantajosa e acho que nesta escola a cultura tem sido nesse sentido (...) fala-se de alguém que já está aqui há 22 anos" (coordenador de departamento).

$\mathrm{Na}$ perspetiva de outro entrevistado, não houve alterações significativas nas práticas deste diretor, o trabalho em equipa existia e continua a existir:

"Muda só o nome, depois as coisas ... porque ele tem uma equipa que trabalha com ele, uma equipa que ele escolhe que já escolhera antes e que era eleita diretamente, (...). As pessoas que estão com ele agora eram pessoas que estavam antes" (representante da autarquia no conselho geral).

Assim, o diretor partilha com os professores algum do seu poder de decisão e solicita opinião aos adjuntos da direção, como afirma uma das entrevistadas:

\begin{abstract}
"O nosso diretor já com muitas restrições dá oportunidades aos grupos (...) o nosso diretor não é assim uma figura... e é por isso que ele se aguenta aqui há tantos anos, é uma pessoa aberta e, portanto, não toma essas decisões. (...) eu acho que não pede a opinião para dizer 'estou acompanhado ou estou sozinho', ele pede genuinamente, é alguém com espírito democrático, felizmente ainda bastante dentro da cabeça" (professora mais antiga).
\end{abstract}

A tomada de decisão por parte do diretor tem subjacente a opinião de outros atores:

"(...) ele (diretor) tem a opinião dos outros no dia a dia, tem do subdiretor, tem de uma série de assessores e, obviamente, quando toma uma decisão ele já ouviu" (professor do conselho geral).

A passagem serena da gestão colegial para a unipessoal teve como principal razão a continuidade da liderança da pessoa que ocupa o cargo de gestão:

“(...) não mudou muito, são as mesmas pessoas, não se muda a mentalidade porque a lei mudou" (presidente do conselho geral);

“(...) como nós temos vindo a atravessar a gestão com a mesma pessoa; ou seja, com o diretor não notamos muito essa diferença (professor do conselho geral); 
“(...) não sentimos grandes mudanças porque o sr. diretor ou antigo executivo sempre teve aquelas linhas orientadoras e, portanto, não fugiu muito do que era e do que é" (funcionário do conselho geral).

Portanto, há uma mudança normativa-legal na relação de poderes no interior na escola. Contudo, na escola em causa, sendo o diretor a mesma pessoa que ocupou cargos diretivos no passado, procura manter a liderança democrática então adquirida, o que nos permite apontar para uma mudança na continuidade. Afigura-se, deste modo, a sobreposição da pessoa ao modelo como aponta os discursos destes atores "o importante não é tanto o modelo, mas antes a pessoa" (coordenador de departamento) e o que "conta mais é a postura das pessoas que lideram" (diretor).

Assim, se com a implementação deste novo modelo de gestão se pretendia a substituição da gestão democrática por uma gestão de feição mais vertical/hierárquica, as margens de ação dos atores, nomeadamente as do diretor, não permitiram a sua implementação na plenitude.

\section{I CONSIDERAÇÕES FINAIS}

O novo modelo de gestão unipessoal que contempla a figura do diretor, surge legitimado pela necessidade de cada escola pública ter um responsável, a quem o ministério pode assacar responsabilidade várias. Contudo, com o estudo em causa tivemos oportunidade de refletir sobre a receção, por parte dos atores educativos, desta nova figura. Salienta-se, assim, a discordância com o processo de eleição do diretor de escola, na medida em que, na perspetiva destes atores, trata-se de uma democracia de tipo mais representativo, quando, no passado recente, assumiu a forma de uma democracia mais participativa. Na ótica de alguns atores, esta nova forma de designação do diretor tem contribuído para a alienação dos atores educativos, no domínio da gestão da escola, acusando, assim, as fragilidades da gestão democrática das escolas.

Acrescem, ainda, opiniões críticas quanto à concentração de poderes na figura do diretor. Não obstante tal posição, em termos discursivos, no que se refere às mudanças no plano da ação, parece não haver alterações significativas, uma vez que, segundo os relatos, os processos adotados assemelham-se aos anteriores, nomeadamente a eleição pelos professores para o cargo de coordenador de departamento, bem como a partilha de poderes do diretor com o vice-diretor e assessores da direção. Neste registo, podemos apontar a existência de alguma mediação dos órgãos colegiais na tomada de decisão, em parte, devendo-se ao perfil do diretor, que não faz depender a sua ação da morfologia organizacional prevista no plano normativo.

Por outro lado, neste modelo de gestão, parece também que a figura do conselho geral não gerou alterações significativas em termos de democracia na escola. Neste 
sentido, segundo os atores escolares entrevistados, assiste-se a uma falta de autonomia da escola e a uma desvalorização do conselho de escola, por parte do Ministério da Educação, reforçando o protagonismo do diretor, tido como necessário na dinâmica do funcionamento deste órgão.

Os dados aqui apresentados e discutidos permitem-nos identificar a importância de uma reflexão aprofundada sobre os sentidos da democracia em contexto escolar.

\section{I AGRADECIMENTOS}

Este trabalho é financiado pelo CIEd - Centro de Investigação em Educação, projetos UID/CED/1661/2013 e UID/CED/1661/2016, Instituto de Educação, Universidade do Minho, através de fundos nacionais da FCT/MCTES-PT.

Agradecemos ao diretor da escola que, para além de garantir excelentes condições para a realização das entrevistas, sempre se disponibilizou para colaborar nesta investigação. Agredemos igualmente aos demais atores que cederam o seu tempo para colaborar com este estudo.

\section{REFERÊNCIAS}

AMADO, João; FERREIRA, Sónia. A entrevista na investigação educacional. In: João Amado (coord), Manual de Investigação Qualitativa em Educação. Coimbra: Imprensa da Universidade de Coimbra, p. 207-232, 2014.

BALL, Stephen. Profissionalismo, gerencialismo e performatividade. Cadernos de Pesquisa, v. 35, n¹26, p.539-564, 2005.

CLARKE, Janet \& NEWMAN, John. The managerial state: power, politics and ideology in the remaking of social welfare. London: Sage Publications, 1997.

FORMOSINHO, João. A regionalização do sistema de ensino. Cadernos Municipais, Revista de Ação Regional e Local, $n^{\circ}$ 3839, Dez., p. 63-67, 1986.

LIMA; Licínio. A gestão democrática das escolas: do autogoverno à ascensão de uma pós-democracia gestionária? Educ. Soc, 35(129), p.1067-1083, 2014.

LIMA, Licínio. Diretor de escola: subordinação e poder. In: António Neto-Mendes, Jorge A. Costa, e Alexandre Ventura (orgs.), A Emergência do Director da Escola, Questões Políticas e Organizacionais, Atas do VI Simpósio sobre organização e gestão escolar. Aveiro: Universidade de Aveiro, p.47-63, 2011.

LIMA, Licínio. A deliberação democrática nas escolas: os procedimentos gerenciais e as decisões políticas. In $\mathrm{M}^{\mathrm{a}}$ Fátima Chorão Sanches, Feliciano Veiga, Florbela de Sousa e Joaquim Pintasilgo, Cidadania e Liderança Escolar. Porto: Porto Editora, p. 39-55, 2007.

MARTINS, Fernanda. Tempos de mudanças na administração da escola pública em Portugal: a (re) emergência do diretor e a concentração de poderes. In Jorge A. Costa, e Alexandre Ventura (orgs.), A Emergência do Director da Escola, Questões Políticas e Organizacionais, Atas do VI Simpósio sobre organização e gestão escolar. Aveiro: Universidade de Aveiro, p. 91-104, 2011. 
MARTINS, Fernanda. Gerencialismo e quase-mercado educacional: a acção organizacional numa escola secundária em época de transição. Tese de Doutoramento em Educação, especialização em Organização e Administração Escolar. Braga: Universidade do Minho, 2009.

YIN, Robert. Estudo de Caso: Planejamento e Métodos. Porto Alegre: Bookman, 2005.

\section{LEGISLAÇÃO}

DECRETO-LEI n 769-A/76, de 23 de outubro, Gestão Democrática dos Estabelecimentos de Ensino Preparatório e Secundário.

DECRETO-LEI n 115-A/98, de 4 de maio, Regime de Autonomia, Administração e Gestão de Estabelecimentos da Educação Pré-Escolar.

Decreto-Lei n 75/2008, de 22 de abril, Regime de Autonomia, Administração e Gestão dos Estabelecimentos Públicos da Educação Pré -Escolar e dos Ensinos Básico e Secundário. 


\section{TEORIA E PRÁTICA NA FORMAÇÃO DOCENTE: POLÍTICAS CURRICULARES}

Sandra Faria Fernandes

Pontifícia Universidade Católica de São Paulo

(PUC/SP)

São Paulo

RESUMO: O trabalho discute os sentidos implícitos presentes na proposta das Diretrizes Curriculares para a formação inicial e continuada de professores, especialmente a questão da unidade teoria-prática. Tal proposta apresenta a práxis como central ao processo formativo docente. A formação docente considera um conjunto teórico-prático imprescindíveis à compreensão do que será observado, apreendido e refletido nas horas de trabalho como futuro professor. No contexto atual, é necessário se repensar a teoria e a prática docente como práxis, como prática docente consciente, quando se almeja a transformação social, com vistas à consecução de um projeto educacional emancipatório. Desterritorializando saberes fundamentais da Educação, as diretrizes curriculares para a formação inicial docente podem impedir a unidade teoria-prática garantidora de uma formação docente apoiada no aprendizado e exercício das práxis educativa. Nesse território de disputas novo acontecimento modifica o cenário, a promulgação da Base nacional Comum Curricular vem aprofundar a discussão, pois, deve promover mudanças no texto da Diretriz Curricular atual, que terá que se adequar à nova legislação. A pesquisa de cunho qualitativo foi realizada com coordenadores das Licenciaturas de Matemática, Química, Física, Física a distâncias e Ciências Biológicas dos cursos de uma Universidade do estado de Minas Gerais. As questões curriculares foram analisadas por meio das concepções trazidas por Sacristán (2000) e Aplle (1997). Após análise ficou explicito que os professores coordenadores das licenciaturas esperam que as modificações sejam urgentes e que as diretrizes curriculares para a formação inicial e continuada de professores preservem a articulação teoria-prática e o caráter autônomo da docência.

PALAVRAS-CHAVE: formação docente, diretrizes curriculares, teoria-prática.

\section{I INTRODUÇÃO}

Este texto resulta de reflexões que se constroem num exercício de espera, no entremuro de uma elaboração não participada, pouco desvelada e, por isso, com significados que clamam por serem identificados e nomeados. Sua análise baseia-se em pesquisa realizada em cursos de Licenciaturas em uma universidade do estado de Minas Gerais 
O propalado lançamento de uma Base Nacional Comum Curricular (BNCC) expôs um conjunto de expectativas e discussões de toda comunidade escolar, desde as academias e seus grupos de pesquisas, até associações científicas e organizações diversas como de pais, professores, reitores, instituições particulares de educação e outras. Criou-se, numa conjuntura política adversa, frágil e confusa, um "acontecimento ainda não acontecido", mas, provocando deslocamentos conceituais e históricos relacionados à institucionalização e oficialização de outros possíveis quadros curriculares para o território nacional. O que isso traz para o âmbito da Educação?

O que este cenário de espera tem produzido em termos de efeitos para os sujeitos do processo educacional? O que tem sido reafirmado, enfraquecido ou revisto quanto aos elementos curriculares em construção-desconstrução? São estas algumas questões que direcionam a feitura dessas reflexões em nosso estudo.

Com o propósito de esclarecer conceitos pertinentes ao tema devemos considerar que teoria e prática são unidades de movimento, uma está contida na outra, em constante processo: "[...] contexto de que fazer, de práxis, quer dizer, de prática e de teoria" (FREIRE 2006, p.106) "[...] toda prática tem um fundamento teórico e viceversa [...] (FREIRE; SHÖR, 2006, p.12). Para Freire, teoria e prática se constituem em uma unidade dialética indissociável.

Dentro do contexto atual, é necessário se repensar a teoria e a prática docente como práxis, como prática docente consciente, quando se almeja a transformação social, com vistas à consecução de um projeto educacional emancipatório que pressupõe a formação de sujeitos autônomos, capazes de produzir seu próprio conhecimento, de posicionar-se diante da realidade, de ter postura crítica e refletir sobre suas ações e as dos outros (GIROUX, 1997, SANTOS, 2003, FREIRE, 2004, GONSALVES 2011).

\section{I O CURRÍCULO EM MOVIMENTO DE CONSTRUÇÃO-DESCONSTRUÇÃO}

Enquanto exercício de compreensão, como efetuar uma leitura acerca da forma como tem sido apresentada tanto a elaboração de uma base curricular como todo o movimento de reação a esta elaboração pela comunidade educacional? Torna-se importante efetuar a busca pelos significados de currículo que permeiam este cenário, atentando para forças e tensões correspondentes às diferentes maneiras de entender o currículo, por grupos e ações diversos.

O currículo, de acordo com Sacristan (2000) tem a pretensão de apresentarse como o reflexo de um esquema socializador formativo e cultural que a instituição escolar tem. Ao se anunciar a necessidade de uma base curricular que abarque todo espectro nacional, anuncia-se também que há um trabalho nas escolas que não corresponde ao que se considera adequado à formação das novas gerações. Há, pois um anúncio ou denúncia de inadequações, equívocos curriculares que precisam ser enfrentados e devidamente substituídos, melhorados no âmbito das instituições 
educativas. Ademais, ao se declarar a emergência de uma outra proposta de base curricular que atenda ao que se denomina "comum", abstrai-se a diferença entre regiões, comunidades, repensa-se o valor e a dimensão das produções culturais comunitárias. Instala-se a perspectiva do risco da pasteurização curricular e a negação dos avanços curriculares quanto à diversidade de culturas que tem sido considerada nos projetos interdisciplinares propostos e realizados por tantas unidades escolares, sob as indicações dos próprios Parâmetros Curriculares Nacionais.

Ainda com base em Sacristan (2000), se o currículo é uma forma de organizar as práticas educativas e, sendo, por isso, também, resultante dessas práticas, cabe captar o que nesta proposta de base curricular está sendo considerado-desconsiderado relevante como prática educativa. Há na espera a construção de perspectivas de perda do que tem feito sentido aos sujeitos do currículo, especialmente, professores e alunos.

Concomitantemente, pelas forças conservadoras que tem tensionado a política nacional e a própria discussão curricular, pais de alunos, representados por associações e organizações diversas, tem apresentado propostas de eliminação de temáticas que paulatinamente vem sendo incorporadas aos currículos desenvolvidos nas escolas, como sexualidade, gênero, etnia e política. Estão sendo questionados valores, mais que conhecimento oficial por meio de um movimento de eliminação do que tem garantido, em termos de formação humana, um certo nível de criticidade e discernimento e deslocamentos sociais importantes, de acordo com Apple (1997). Tais temáticas, ao se tornarem presentes no currículo escolar, promovem reflexão de um real pouco problematizado e, por isso, ainda em fase de experimentação, onde professores e gestores estão tateando modos, enfrentando as diferenças e assumindo a diversidade de minorias sociais.

Acompanhar este momento de espera que provoca debates, aciona posturas é também identificar que há uma desconstrução paralela de um currículo, entendido como prática educativa, que tem incomodado famílias, que provocam estranhamento e, por isso, enfraquecendo um olhar conservador, fracionado social e culturalmente. Ao se apresentar a proposta, pois, de uma base curricular, observa-se a possibilidade de eliminação do que não corresponde ao ideal de uma sociedade sem conflitos, sem diferenças, sem diversidade.

Há aí um elemento de pensar coletivo sobre currículo como prática educativa que merece ser debatido e enfrentado pela comunidade escolar (professores-gestãoalunos-pais) para muito além de qualquer documento oficial que se apresente. É a necessidade de entender o currículo como construção coletiva, cultural e histórica que ultrapassa o saber outorgado pelas ciências, porque vivido e elaborado no cotidiano por sujeitos que concretizam toda e qualquer proposta oficial, corroborando Grundy (1987), para o qual o currículo não pode estar fora e nem prévios às experiências humanas.

O documento apresentado pelos órgãos oficiais da BNCC, organizado em forma 
de "direitos de aprendizagem", explicita algumas opções em termos de currículo que trarão consequência para os currículos de formação docente. Em primeiro lugar, ao se referir ao direito de aprender, afirma-se que o currículo é um conjunto de saberes que são imprescindíveis e inegociáveis para todo e qualquer brasileiro. Há, subjaz ao termo, a educação escolar que deve se realizar privilegiando o sentido individual e, consequentemente, relativizando o lugar do social e de coletivo específicos, como culturas de minorias e imperando o elenco de conteúdo, esvaziando o significado histórico-crítico de saberes construídos e em construção. Entendendo que tal base curricular, assim apresentada, interferirá no currículo dos cursos de formação docente, cabe alguma reflexão. Este caráter individualizante e uniforme da BNCC será, em potencial, transferido também para os currículos de formação de professores, secundarizando transversalidade e interdisciplinaridade das práticas docentes.

Em segundo lugar, considerando que o primeiro documento apresentado caracteriza-se por detalhamentos de conteúdo, restringe o espaço de autonomia docente na escolha, no planejamento, na execução e na avaliação do processo ensinoaprendizagem. As brechas de autonomia diminuem consideravelmente e tal pode ser percebido já na Resolução CNE/CP n 2 /2015 das Diretrizes Curriculares para a formação inicial e continuada de professores que enfatiza a gestão em detrimento da própria docência. Observa-se que ao professor em formação, cabe mais prática que teoria e uma carga-horária expressiva de estágio com vistas a acompanhar processos de gestão escolar. Além disso, tal resolução também diminui o sentido coletivo do trabalho docente e das experiências acadêmicas no decorrer da formação inicial.

Espera-se que após a publicação da Resolução CNE/CPN², de 22 de Dezembro de 2017 que institui e orienta a implantação da BNCC, que em seu capítulo V, artigo 17, rege que: "na perspectiva de valorização do professor e da sua formação inicial e continuada, as normas, os currículos dos cursos e programas a eles destinados devem adequar-se à BNCC, [...]devendo ser implementado no prazo de dois anos", provoque modificações urgentes como rege a legislação nas diretrizes curriculares para a formação inicial e continuada de professores em vigor, preservando agora a articulação teoria-prática e o caráter autônomo da docência

O currículo, ao ser considerado neste texto, como sistematização, reatualização e ressignificação de experiências de aprendizagem, assume o seu caráter de construção e de elaboração coletiva a partir de um certo e determinado contexto no qual cada escola está inserida.

Neste sentido, o risco de pasteurização de formação, via uma base curricular em nível nacional apresentada de forma engessada, provoca a necessidade de enfrentar o diálogo, a dissonância e as tensões que as políticas oficiais trazem. Pois, se o currículo é, de acordo com Moreira (2003), um instrumento que organiza, preserva e renova os conhecimentos, uma base nacional curricular, como documento oficial, deve garantir a produção curricular própria a cada escola a partir de referenciais e não de conteúdos fragmentados e listados em detalhamentos exagerados. Não apenas 
diminui a autonomia docente como um documento oficial apresentado desta forma, traduz a insuficiência formativa do próprio professor, desqualificando o seu próprio processo de formação

\section{I A PESQUISA}

A pesquisa teve como objetivo entender como as determinações oficiais do currículo para a formação de professores, (mudança nas diretrizes curriculares) podem influenciar as necessidades de articulação teoria e prática que subjazem a qualidade da educação pretendida em que os professores irão atuar.

De abordagem qualitativa a pesquisa utilizou o método de entrevista coletiva. Inicialmente realizou-se durante todo o semestre, junto aos coordenadores dos cursos de Licenciatura reuniões semanais com debates sobre o tema da pesquisa (a implantação da Resolução CNE/CP n 2 /2015 Diretrizes Curriculares para a formação inicial e continuada de professores). Com o propósito de otimizar o trabalho, o roteiro delineado para os debates foi utilizado para a realização de uma entrevista coletiva com os respectivos coordenadores de 5 cursos de Licenciatura, a saber: Licenciatura em Matemática, Licenciatura em Química, Licenciatura em Física, Licenciatura em Física a distâncias e Licenciatura em Ciências Biológicas, considerando que os aspectos da pesquisa estavam na pauta em todos os encontros, a entrevista coletiva foi realizada somente no último encontro do semestre. Cabe destacar que, para efeito de contabilização para a organização de dados, as respostas dos coordenadores foram discriminadas em: Licenciatura em Matemática (L.M); Licenciatura em Física(L.F.); Licenciatura em Física a distância (L.F.ead); Licenciatura em Química(L.Q.); Licenciatura em Ciências Biológicas(L.C.B.)

\section{I RESULTADOS E DISCUSSÕES}

A proposta curricular aqui discutida apresenta a prática como elemento central para o processo formativo docente. Torna-se necessário, assim, problematizar acerca de alguns elementos presentes nas Diretrizes. O primeiro elemento refere-se à distribuição de carga-horária e conteúdos elencados em disciplinas. O aumento da carga-horária de atividades a serem desenvolvidas em unidades escolares da Educação Básica não garante, por si só, a articulação teoria-prática na formação docente. Na fala dos professores coordenadores temos:

Vejo com muita preocupação e acho que será muito difícil a gente garantir essa carga-horária em curso noturno (L.F.ead).

Além da questão de sermos um curso noturno, ainda temos que diversificar as disciplinas com o número restrito de professores que temos na parte pedagógica (L.Q.) 
Agora, com a proposta da Residência Pedagógica, como o aluno que trabalha ou que é de fora da cidade vai compatibilizar os seus horários? (L.F)

Penso que isso aparece agora porque há exatamente a necessidade de formar o professor-pesquisador. Essa articulação pode ser um caminho para a gente garantir maior aproximação entre teoria e prática de ensino. (LCB)

O segundo elemento refere-se à diminuição de disciplinas como História da Educação e Filosofia da Educação que não supõe o abrandamento da teorização descontextualizada. Parte-se, pois do pressuposto de que a formação para o exercício da docência supõe um conjunto de elementos teóricos imprescindíveis para a compreensão do que será observado, apreendido e refletido nas horas de trabalho discente, aquele que será o futuro professor nas escolas, seja como estagiários ou observadores da prática docente, seja como atividade de ensino, de extensão ou de pesquisa.

Os impactos virão na sobrecarga de trabalho dos docentes para oferecerem diversificação de disciplinas para atender as 3200 horas (L.C.B.)

Além disso, tem toda a parte de orientação do PIBID e Residência Pedagógica que estamos averiguando que não há professor suficiente para atender aos projetos. (L.M.)

E não há nenhuma possibilidade de termos abertura de vaga para a contratação de professores e temos um número muito restrito de docentes da área pedagógica ou que tem formação em ensino de... (L.Q)

Sabemos que é importante a articulação com o mestrado, mas com o aumento das horas na grade, como articular Mestrado e graduação (L.F.)

O texto não ressalta tanto a importância dessa articulação. Vejo como uma recomendação. E a universidade que não tem mestrado, o que vai articular? (L.F.ead)

Entendo que talvez o foco deva ser na pesquisa educacional para que ocorra essa articulação. O como, vamos ter que construir juntos (nós, os coordenadores) (L.Q)

De cunho interpretativo-reflexivo este estudo busca a ampliação do escopo teórico-metodológico na reconfiguração das mudanças curriculares dos programas de formação docente, considerando os riscos de um esvaziamento crítico-reflexivo quando instala-se a prática como ponto de partida da formação docente. Tem-se, assim, nos arranjos e adaptações de propostas curriculares nos cursos de formação de professores, um aumento significativo de disciplinas (currículo em formato disciplinar) denominadas "Práticas de Ensino" que de diversificam em propostas que correspondem a um saber-fazer esvaziado de teoria, como confecção de material didático, domínio de tecnologia educacional, habilidades comunicacionais que enfatizam performa-se docentes.

Destituindo e desterritorializando saberes fundamentais da Educação, as diretrizes curriculares para a formação inicial docente podem impedir uma articulação teoriaprática garantidora de uma formação docente apoiada no aprendizado e exercício da práxis educativa. 


\section{I A ESPERA DE POSSIBILIDADES PARA ALÉM DO OFICIAL}

Este tempo entre o que se está discutindo no campo da autoridade governamental e o que será apresentado como documento oficial de políticas públicas de educação, vem sendo preenchido por indagações, sensações, alimentado de boatos, eivado de sugestões e manifestos formais de contestação. Há, nesse intervalo, a possibilidade de revisitar o que se denomina o conhecimento oficial e recuperar o entendimento de Apple (1997) acerca dos arranjos que um grupo hegemônico determinado engendra para a obtenção de acordos que possam manter garantidos os seus interesses, pois “...os poderosos não são assim tão poderosos. As políticas do conhecimento oficial são o resultado de acordos ou compromissos." (ibid, 1997, p. 24).

Como o autor supracitado destaca, é preciso, ao analisar propostas e políticas curriculares, indagar o que nelas ou delas é verdadeiro a partir da experiência vivida, considerando que tais propostas, para se concretizarem, devem estar articuladas a problemas reais, contextos específicos. No lastro deste raciocínio cabe enfatizar que o currículo enquanto produção de significados, ultrapassa qualquer documento oficial e o modifica no cotidiano escolar num constante processo de construção coletiva de saberes e experiências definidoras de uma trajetória formativa. Assim, mesmo que as concessões se façam necessárias, seja ao livre-mercado, seja no engessamento ou disciplinarização de uma BNCC, ou uma nova Diretriz Curricular, será no embate com o real que o currículo será rearranjado, remodelado aos contextos específicos.

Nestes rearranjos que cabe aos sujeitos do processo, principalmente professores e pesquisadores, repensarem seu papel, reverterem a ordem e se colocarem como agentes responsáveis pela elaboração e vivência de um currículo que ultrapasse o oficial proposto.

Importante, pois considerar que o resultado de uma BNCC, mesmo que apoiado em critérios e lógicas constituintes de um sistema de avaliação mais imposto que construído, mais estrangeiro que nacional, mais voltado para definir quadros para o mercado que para o próprio desenvolvimento e formação humanos, não será apenas para atender os desígnios impostos. Mas, tal BNCC deverá comportar espaços e brechas para a infiltração do social, elementos da cultura que se reelabora localmente, dos deslocamentos identitários que se inscrevem no próprio espaço escolar.

Se neste tempo de espera há a marginalização de grupos de pesquisa, se são negados os trabalhos e presenças de sujeitos curriculantes (Macedo, 2013) nas instâncias de tomada de decisões, será na esfera do cotidiano escolar que a BNCC será convertida em currículo. Nesta conversão estará o que deverá ser conservado e o que deverá ser subvertido e mudado em função das porosidades próprias à cultura da escola. É a espera-ação do intervalo da espera.

Então, também será na esfera do devir que os currículos para a formação inicial e continuada de professores se concretizarão na consubstancia de processos formativos de caráter reflexivo e coletivo, trazendo a teoria cada vez mais iluminadora 
de práticas para a emancipação de sujeitos, se negados por BNCC se farão presentes na experiência da própria docência em formação nos espaços escolares, numa arranjo cambiante entre academia e escola, entre comunidade e âmbitos do aprender e do ensinar, tendo o aluno-licenciando em formação como elemento mediador dessas articulações, pois:

"Ninguém caminha sem aprender a caminhar, sem aprender a fazer o caminho caminhando, sem aprender a refazer, a retocar o sonho por causa do qual a gente se pôs a caminhar" (FREIRE, 2000, p. 155)

\section{REFERENCIAS}

APPLE, Michael. Conhecimento oficial: a educação democrática numa era conservadora. Petrópolis, Vozes 1997.

FREIRE, Paulo. Pedagogia da Esperança. São Paulo, Paz e Terra 2000. 2004. Pedagogia da Autonomia: saberes necessários à autonomia. 29ed. São Paulo: Paz e Terra, Professora sim, tia não: cartas a quem ousa ensinar.16. ed. São Paulo: Olho d'água, 2006. 2006. ; SHÖR, Ira. Medo e ousadia: o cotidiano do professor.11. ed. Rio de Janeiro: Paz e Terra,

GIROUX, H.A. Os professores como intelectuais: rumo a uma pedagogia crítica da aprendizagem. Porto Alegra: Artes Médicas, 1997.

GONÇALVES, Y.P. Qualidade oficial, indicadores do MEC. In: COIMBRA, C.L. et al (orgs). Qualidade em Educação. Curitiba/PR: Editora CRV, Série Currículo: Questões Atuais, vol 4, 2011.

GRUNDY, S. Curriculum, The Falmer Press.1987

MACEDO, Roberto Sidnei. Atos de Currículos: uma incessante atividade etnometódica e fonte de análise de práticas curriculares. Revista Currículo sem Fronteiras, v. 13, n. 3, p. 427-435, set /Dez 2013.

MOREIRA, Antônio Flavio. Currículo na Contemporaneidade: Incertezas e Desafios Cortez 2003.

SACRISTAN, Gimeno. O Currículo, uma reflexão sobre a prática. Porto Alegre: Editora Artmed, 2000.

SANTOS, B. de S. Um discurso sobre as ciências. São Paulo: Cortez, 2003. 
SOBRE AS ORGANIZADORAS

Gladys Batista Picaglie - Licenciada em Letras pela Universidade Estadual de Ponta Grossa ( UEPG). Pós-Graduada em Psicopedagogia. Cursos de Extensão: Associação Brasileira de Dislexia (ABD), em Raciocínio lógico da Matemática e Panlexia. Atualmente é Psicopedagoga Clinica e Assessora de Edição na Atena Editora.

Antonella Carvalho de Oliveira - Licenciada em Pedagogia. Mestre em Engenharia de Produção e Doutora em Ensino de Ciência e Tecnologia pela Universidade Tecnológica Federal do Paraná (UTFPR). Atualmente é Professora da Secretaria de Estado da Educação do Paraná no CEEBJA Professor Odair Pasqualini que atende alunos com privação de liberdade na Penitenciária Estadual de Ponta Grossa. É Editora Chefe da Atena Editora e tem entre suas principais atribuições: coordenar a equipe editorial, fixar o escopo das publicações, definir a política editorial, monitorar e auxiliar o trabalho dos editores e adequar a composição do conselho editorial aos propósitos da editora. 
Agência Brasileira do ISBN

ISBN 978-85-7247-103-9

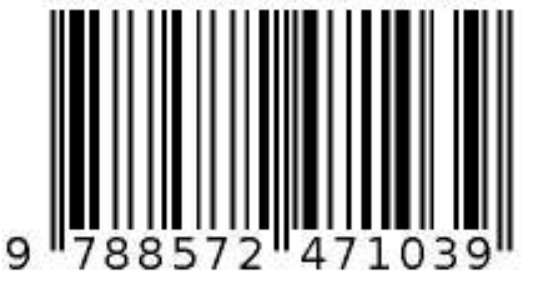

